\section{CRR른 REPORT 83-24}

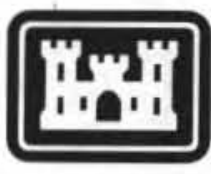

US Army Corps of Engineers

Cold Regions Research \& Engineering Laboratory

Sensitivity of plant communities and soil flora to seawater spills, Prudhoe Bay, Alaska

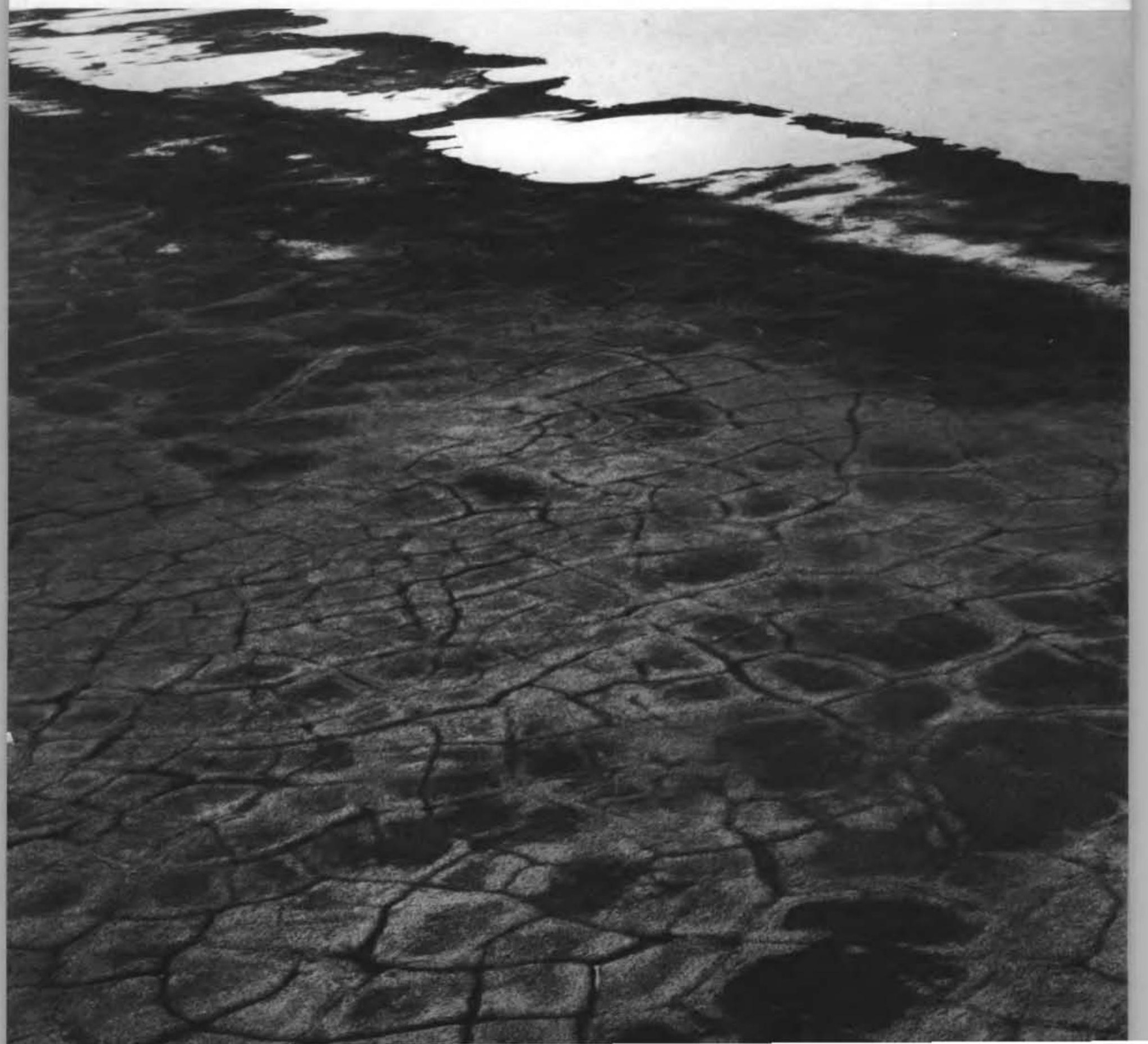




\section{CRREL Report 83-24}

September 1983

\section{Sensitivity of plant communities and soil flora to seawater spills, Prudhoe Bay, Alaska}

C.L. Simmons, K.R. Everett, D.A. Walker, A.E. Linkins and P.J. Webber 


\begin{tabular}{|c|c|}
\hline REPORT DOCUMENTATION PAGE & $\begin{array}{l}\text { READ INSTRUCTIONS } \\
\text { BEFORE COMPIETING FORM }\end{array}$ \\
\hline $\begin{array}{l}\text { 1. REPORT NUMBER } \\
\text { CRREL Report } 83.24\end{array}$ & 3. RECIPIENT'S CATALOG NUMBER \\
\hline \multirow[t]{2}{*}{$\begin{array}{l}\text { 4. TITLE (and Subtitie) } \\
\text { SENSITIVITY OF PLANT COMMUNITIES AND SOIL FLORA } \\
\text { TO SEAWATER SPILLS, PRUDHOE BAY, ALASKA }\end{array}$} & 5. TYPE OF REPORT A PERIOD COVERED \\
\hline & 6. PERFORMING ORG. REPORT NUMBER \\
\hline $\begin{array}{l}\text { 7. AUTHOR(a) } \\
\text { C.L. Simmons, K.R. Everett, D.A. Walker, A.E. Linkins } \\
\text { and P.J. Webber }\end{array}$ & $\begin{array}{l}\text { 8. CONTRACT OR GRANT NUMBER( } s) \\
\text { DACA-89-8I-M-0214 }\end{array}$ \\
\hline $\begin{array}{l}\text { 9. PERFORMING ORGANIZATION NAME AND ADDRESS } \\
\text { Institute of Arctic and Alpine Research } \\
\text { University of Colorado } \\
\text { Boulder, Colorado } 80309\end{array}$ & $\begin{array}{l}\text { 10. PROGRAM ELEMENT, PROJECT, TASK } \\
\text { AREA \& WORK UNIT NUMBERS }\end{array}$ \\
\hline \multirow{2}{*}{$\begin{array}{l}\text { 11. CONTROLLING OFFICE NAME AND ADDRESS } \\
\text { U.S. Army Cold Regions Research and Engineering Laboratory } \\
\text { Hanover, New Hampshire } 03755\end{array}$} & $\begin{array}{l}\text { 12. REPORT DATE } \\
\text { Seplember } 1983\end{array}$ \\
\hline & $\begin{array}{l}\text { 13. NUMBER OF PAGES } \\
43\end{array}$ \\
\hline \multirow{2}{*}{$\begin{array}{l}\text { 14. MONITORING AGENCY NAME a ADDRESS(If different from Controlling Office) } \\
\text { Ecological Research Division } \\
\text { Department of Energy } \\
\text { Washington, D.C. } 20545\end{array}$} & $\begin{array}{l}\text { 15. SECURITY CLASS, (of thia roport) } \\
\text { Unclassified }\end{array}$ \\
\hline & $\begin{array}{l}\text { 15a. DECLASSIFICATION/DOWNGRADING } \\
\text { SCHEDULE }\end{array}$ \\
\hline
\end{tabular}

\section{DISTRIBUTION STATEMENT (of this Report)}

Approved for public release; distribution unlimited.

17. DISTRIBUTION STATEMENT (of the abstract ontored in Block 20, if different from Report)

18. SUPPLEMENTARY NOTES

19. KEY WORDS (Continue on reverse side if necessary and Identify by block number)

Arctic plants

Saltwater

Seawater

Soil flora

Tundra

20. ABSTRACT (Continue an reverse side if necossary and identify by block number)

Secondary recovery of oil at Prudhoe Bay, Alaska, will involve transporting large quantities of seawater in elevated pipelines across tundra for injection into oil-bearing rock strata. The possibility of a pipeline rupture raises questions concerning the effects of seawater on tundra vegetation and soils. To evaluate the relative sensitivities of different plant communities to seawater, eight sites representing the range of vegetation types along the pipcline route were treated with single, saturating applications of seawater during the summer of 1980.

Within a month of the treatment 30 of 37 taxa of shrubs and forbs in the experimental plots developed clear symptoms of stress, while none of the 14 graminoid taxa showed apparent adverse affects. Live vascular plant cover was thus reduced by 89 and $91 \%$ in the two dry sites and by 54,74 and $83 \%$ in the three moist sites, respectively. 


\section{Abstract (cont'd.).}

Live (green) bryophyte cover was markedly reduced in the moist experimental sites in 1981. Bryophytes in all but one of the wet-site experimental plots were apparently unaffected by the seawater treatment. Two species of foliose lichens treated with seawater showed marked deterioration in 1981. All other lichen taxa were apparently unaffected by the seawater treatment.

The absorption and retention of salts by the soil is inversely related to the soil moisture regime. In the wet sites, conductivities approached prespill levels within about 30 days. In such sites, spills at the experimental volumes are quickly diluted and the salts flushed from the soil. In the dry sites, on the other hand, salts are retained in the soil, apparently concentrating at or near the seasonal thaw line.

On spill sites, microbial-related soil respiration and hydrolysis of cellulose and organic phosphorus were significantly reduced, as were soil enzymes and viable microbial biomass, for up to one year after treatment. Ectomycorrhizal roots of Salix on the treated plots showed a significant reduction in viable biomass, iumber of mycorrhizal roots, and respiration rates of the viable roots. 


\section{PREFACE}

This report was prepared by Carol L. Simmons,* Institute of Arctic and Alpine Research (INSTAAR), University of Colorado, Boulder; K.R. Everett, Institute of Polar Studies, Ohio State University, Columbus; Donald A. Walker, INSTAAR; A.E. Linkins, Department of Biology, Virginia Polytechnic Institute and State University, Blacksburg; and Patrick J. Webber, INSTAAR. This work was supported by CRREL under Contract No. DACA-89-81-M-0214 with support from the Department of Energy and in cooperation with the Sohio-Alaska Co. and Alantic Richfield Co. Site visits during May, June and August 1981 were supported by grants from the Sohio-Alaska Co. to the senior author.

A number of CRREL personnel participated in the planning and execution of the experiment, including Dr. Jerry Brown, Lawrence Johnson, Thomas Jenkins, Randall Steen and Bruce Brockett. Others who helped in various ways included Susan Degler, Sohio-Alaska Petroleum Company; and Kate Palmer and Donald Mills, University of Colorado. Bryophyte determinations were by Barbara Murray, University of Alaska. Dr. William Weber and Dr. Sam Shushan, University of Colorado, assisted with vascular plant and lichen determinations. Dr. Erik Bonde, University of Colorado, and Barbara Gartner, CRREL, offered many helpful sug. gestions.

The contents of this report are not to be used for advertising or promotional purposes. Citation of brand names does not constitute an of fical endorsement or approval of the use of such commercial products.

-Current address: Department of Forestry and Resource Management, University of California, Berkeley. 


\section{CONTENTS}

Abstract

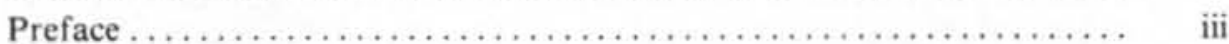

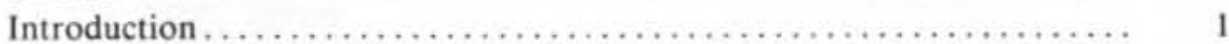

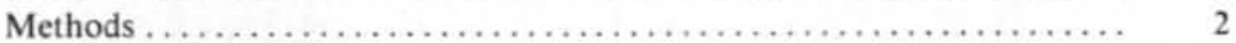

Site selection and preparation........................... 2

Prespill assessment.................................. 5

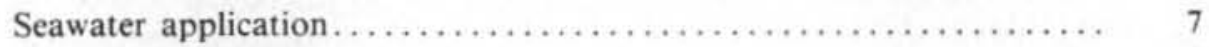

Postspill assessment................................ 8

Enzyme assay and analysis of soil flora ................... 9

Results and discussion................................ 9

Soil-solution conductivities........................... 9

Vascular plant response ................................ 11

Cryptogam response................................ 21

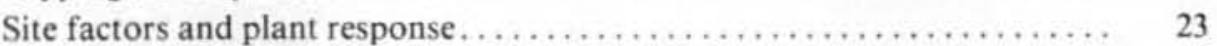

Soil flora and extracellular soil enzymes....................... 28

Limitations of this study . . . . . . . . . . . . . . . . . . . . . . . 29

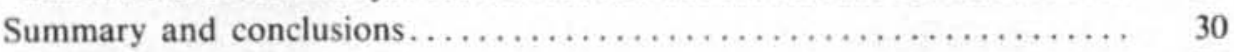

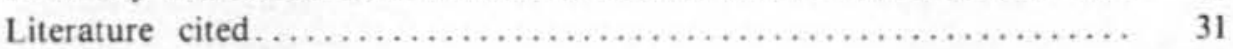

Appendix: Plant taxa included in this study $\ldots \ldots \ldots \ldots \ldots \ldots \ldots \ldots \ldots, 33$

\section{ILLUSTRATIONS}

Figure

1. Locations of the seawater spill study sites .................. 2

2. Schematic of an experimental site ........................ 2

3. Application of seawater at the West Dock mesic site............ 3

4. Positions of suction lysimeters with respect to composite soil profiles for each of the eight experimental sites.................. 3

5. Vegetation at three sites........................... 5

6. Plant community composition by growth form before the spill...... 7

7. Responses of vascular plants to a seawater spill.............. 13

8. Differences between control and experimental plots in $1981 \ldots \ldots \ldots .24$

9. Percent live cover for all vegetation in the experimental plots prior to the seawater treatment in 1980 and one year after the treatment....

\section{TABLES}

\section{Table}

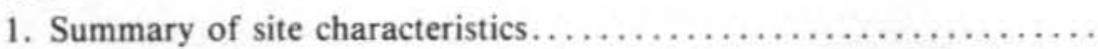

2. Duration of the seawater application and the area covered by the seawater at each location. 
3. Soil-solution conductivities at the spill sites................ 10

4. Prespill and postspill ion concentrations in two study plots......... 11

5. Degree and character of physiological stress exhibited by plants affect-

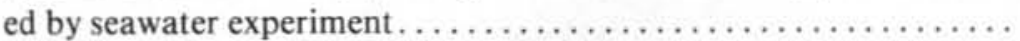

6. Changes in percent cover for principal vascular taxa and total live vascular plant cover by site for 1980 and $1981 \ldots \ldots \ldots \ldots \ldots \ldots \ldots$.

7. Numbers of vascular plant taxa in the experimental and control plots

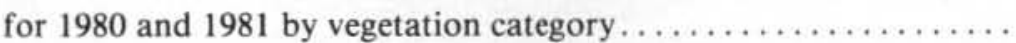

8. Numbers of individuals of selected vascular plant taxa in the experimental and control plots for 1980 and $1981 \ldots \ldots \ldots \ldots \ldots \ldots \ldots$

9. Changes in percent live vegetation cover by growth form in the experimental and control plots for 1980 and $1981 \ldots \ldots \ldots \ldots \ldots \ldots$

10. Vascular plant response in relation to site factors.

11. Soil enzyme activity in experimental and control plots at Drill Site No. 2, Pad F and West Dock.

12. Soil and ectomycorrhizal root respiration rates in experimental and control plots at Drill Site No. 2, Pad F and West Dock.

13. Ectomycorrhizal root composition in experimental and control plots at Drill Site No. 2, Pad F and West Dock 


\title{
SENSITIVITY OF PLANT COMMUNITIES AND SOIL FLORA TO SEAWATER SPILLS, PRUDHOE BAY, ALASKA
}

\author{
C.L. Simmons, K.R. Everett, D.A. Walker, \\ A.E. Linkins and P.J. Webber
}

\section{INTRODUCTION}

The Waterflood Project, which will begin operation in the oil field at Prudhoe Bay, Alaska, in 1984, is a system for secondary recovery of oil that will involve transporting seawater across tundra and injecting it into oil-bearing rock strata. The project has raised questions concerning the effects of seawater on tundra vegetation and soils. Approximately $36.9 \mathrm{~km}$ (23 miles) of low-pressure pipeline and $160 \mathrm{~km}$ ( 99 miles) of high-pressure pipeline will be constructed to transport seawater from Prudhoe Bay to the injection sites. Over most of its length the elevated pipeline will follow existing oil pipeline corridors. The piped seawater will be heated to $4.4^{\circ} \mathrm{C}\left(40^{\circ} \mathrm{F}\right)$ or more and treated with a biocide. The U.S. Army Corps of Engineers (1980) estimated that an accidental rupture of a low-pressure line could release as much as 16,400 $\mathrm{m}^{3}\left(4,300,000 \mathrm{gal}\right.$, or $\left.1.8 \mathrm{gal} . / \mathrm{ft}^{2}\right)$ of seawater onto the surrounding tundra; however, "reasonable worst-case" spill estimates range from $1400 \mathrm{~m}^{3}$ ( 370,000 gal.) for the high-pressure lines to 5000 $\mathrm{m}^{3}(1,300,000 \mathrm{gal}$. $)$ for the low-pressure lines. The larger spill could inundate as much as 25 ha $(60$ acres) of tundra, depending on the ground conditions, topography and other environmental factors, and on the effectiveness of containment efforts.

Although some observations on the effects of storm surges on terrestrial plant communities along the arctic coast have been made (Reimnitz and Mauer 1979), little is known about the tolerance of tundra plants for seawater. In a geobotanical mapping study, Prudhoe Bay plant communities were rated according to their predicted sensitivities to a saturating seawater spill during the growing season (Walker and Webber 1980). Plant communities on dry sites are considered to be more sensitive than those on wet sites, with moist-site communities having an intermediate sensitivity. This prediction is based on the premise that moist and wet sites are likely to retain less seawater initially and are subject to greater natural flushing by freshwater than are the dry sites.

A seawater spill would also be expected to affect the soil flora, Because most, if not all, vascular plants are mycorrhizal (Antibus and Linkins 1978, Linkins and Antibus 1978) and because the mycorrhizal roots seem to reside in the upper organic horizons of the tundra soils, a seawater spill would affect the vascular plants as well. In addition to increasing the active absorptive surface area of the root system, the mycorrhizal fungus also increases the concentration of available nutrients by secreting hydrolytic extracellular enzymes (Burns 1978, Linkins and Antibus 1982a, b). These enzymes are generally adsorbed to the soil particles (Ladd and Butler 1975, McLaren 1975, Burns 1978) and can be made soluble by buffer or salt solutions varying from 10 to $150 \mathrm{~mm}$ ionic concentration (Ladd and Butler 1975, Spaulding 1977, Nannipieri et al. 1980, Sinsabaugh et al. 1981). Consequently, a seawater spill could affect tundra plants directly by decreasing root respiration, or it could affect them indirectly by decreasing total soil enzyme activity or soil microbe respiration.

The following study was undertaken to monitor the movement of salts through the soil and to obtain information about the effects of seawater spills on tundra vegetation, soil enzyme activity, soil respiration and mycorrhizal root respiration. The results will help direct further investigation into the effects of seawater on tundra ecosystems and will be useful in preparing environmental impact statements about transporting seawater over tundra. This information will become more important with the increased use of secondary oilrecovery methods on the Arctic Coastal Plain. 


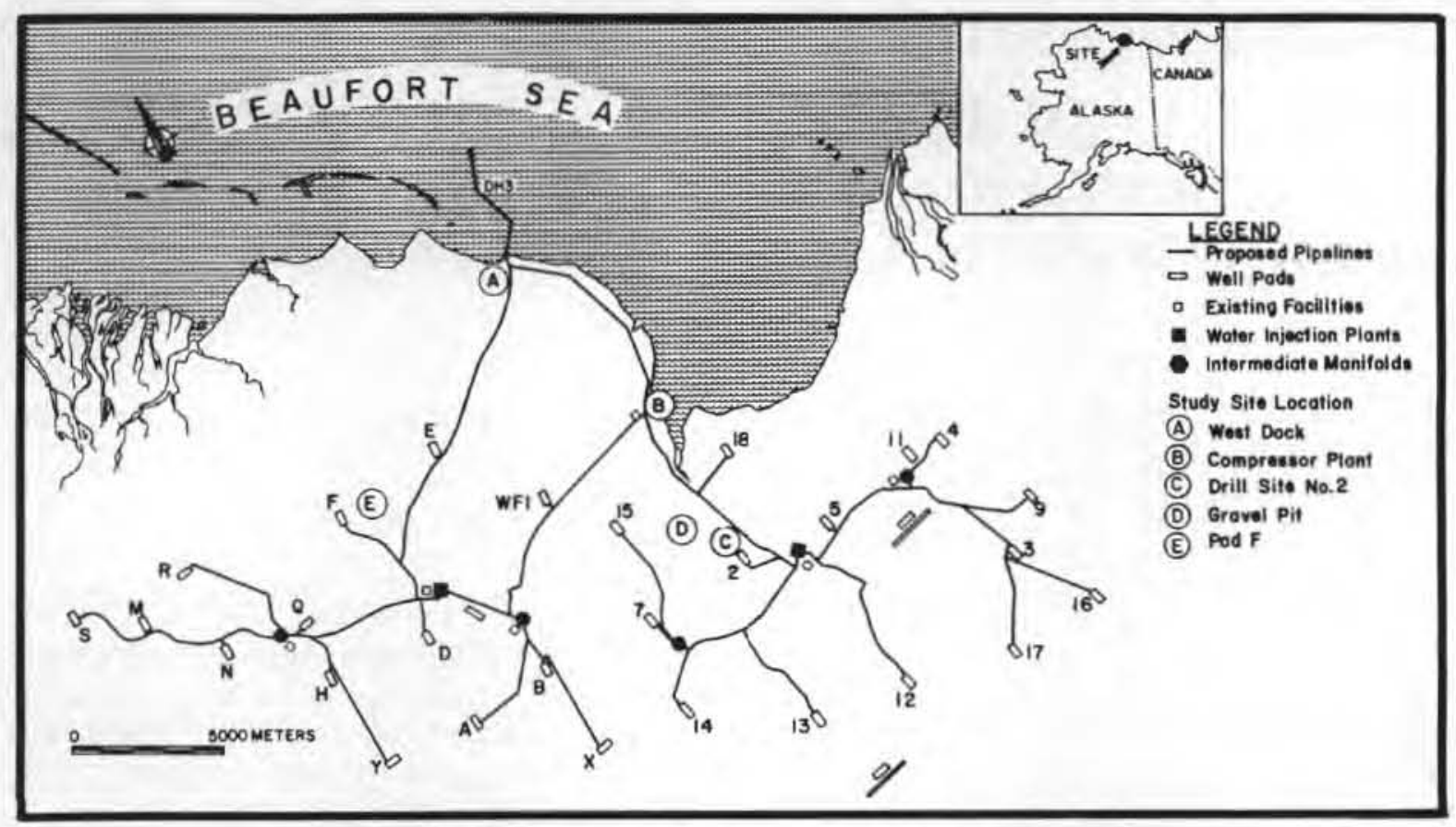

Figure 1. Locations of the seawater spill study sites.

\section{METHODS}

\section{Site selection and preparation}

Eight study sites were established at five locations in the Prudhoe Bay area in the summer of 1980 (Fig. 1). All of the sites are in areas that were studied in vegetation analyses by Walker et al. $(1978,1980 \mathrm{a})$. The sites include dry, mesic and wet tundra with either slighty acidic (pH 5.3-6.2) or alkaline ( $\mathrm{pH} 7.1-8.5$ ) soils. Three of the sites are located on the coast, where the soils and vegetation are influenced by the ocean; the remaining five sites are inland. Together the sites represent the predominant soil and vegetation types that occur along the proposed routes of the Waterflood Project pipelines.

Sites representing a given moisture category (dry, mesic or wet) were selected for their homogeneity of landform characteristics. The dry sites were situated on an exposed coastal bluff at Compressor Plant \#1 (site B) and on a low, exposed ridge near Oxbow Gravel Pit (site D). Both of these sites were on slightly sloping $(<2 \%)$ ground with low hummocks. Mesic and wet sites were selected at each of three locations. These represent inland acidic, inland alkaline and coastal acidic tundra (sites E, C and A, respectively). The mesic sites at all three locations were in the basins of low-centered polygons. The wet sites were on the margin of a pond at Arco Drill Site No. 2 and in patterned terrain at West Dock and Sohio Pad F. Except the dry sites, all sites were on level ground.

Three experimental plots and one control plot were established at each study site (Fig. 2). Small surveying stakes were used to mark the corners of the $1-m$-square plots. The experimental design

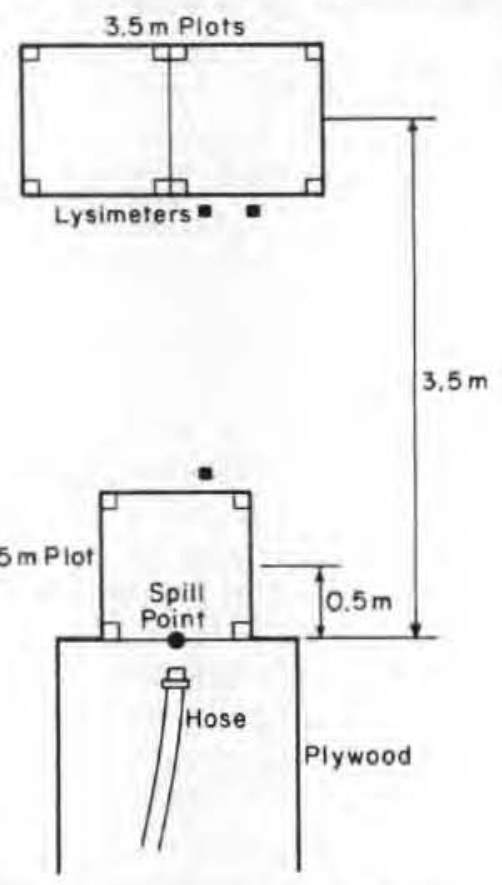

Figure 2. Schematic of an experimental site. 


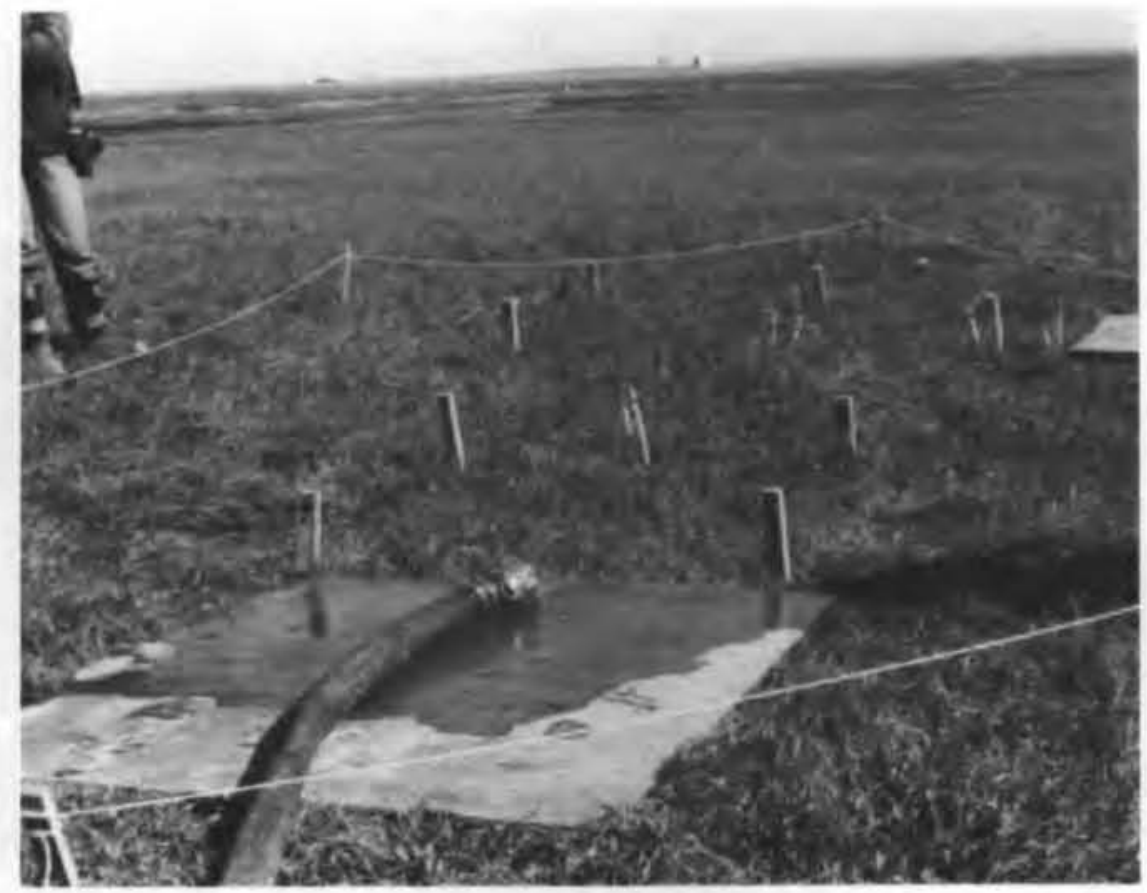

Figure 3. Application of seawater at the West Dock mesic site. The plastic tubes attached to the lysimeters can be seen at the center and the right.

called for spilling the seawater from a hose at the spill point (Fig. 2) and allowing the water to follow the natural contours of the earth over the study plots. The three experimental plots were 0.5 and $3.5 \mathrm{~m}$ from the spill point in the predicted path of the water. A fourth plot was established outside each spill area to serve as a control. An additional control plot treated with freshwater was desirable, but the added complexity and significant expense involved did not seem justified. Once the plots were established, each study site was roped off to discourage traffic in the spill area (Fig. 3).

Suction lysimeters of two sizes were installed in each experimental site about 10 days before the seawater was applied. The larger lysimeters had ceramic cylinders $4 \mathrm{~cm}$ in diameter and $12 \mathrm{~cm}$ long, the bottom centimeter of which was porous. The smaller lysimeters had porous ceramic cylinders approximately $1 \mathrm{~cm}$ in diameter and $4 \mathrm{~cm}$ long. Plastic tubing attached to the ceramic cylinders extended above the soil surface so that the soil solution could be extracted.

The lysimeters were placed at depths determined by the texture of the soil as identified in the soil profiles (Fig. 4). The smaller lysimeters were pre-

Figure 4. Positions of suction lysimeters with respect to composite soil profiles for each of the eight experimental sites.
West Dock(met) West Dockimesic)

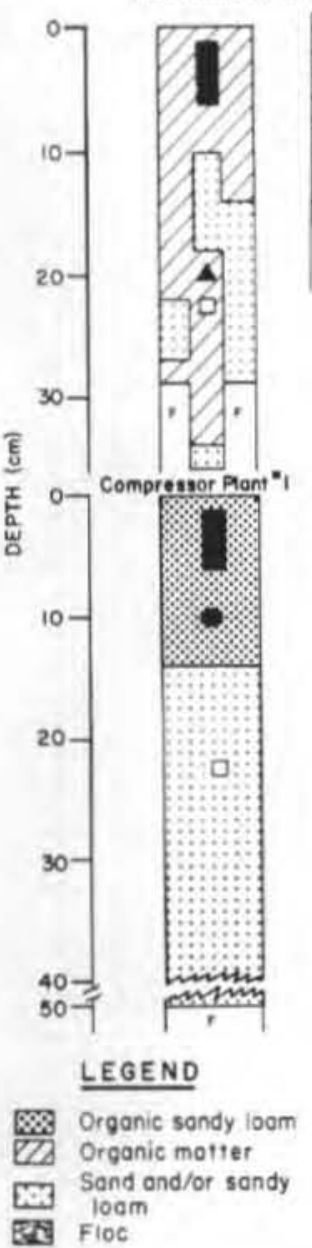

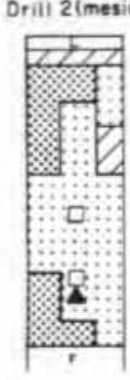

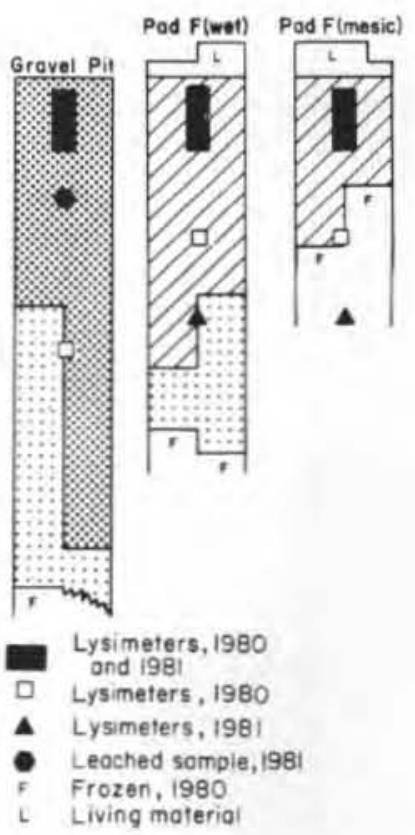


Table 1. Summary of site characteristics.

\begin{tabular}{|c|c|c|c|c|c|c|c|c|c|c|c|}
\hline \multirow[b]{2}{*}{ Site } & \multirow[b]{2}{*}{$\begin{array}{c}\text { Major } \\
\text { landform }\end{array}$} & \multirow{2}{*}{$\begin{array}{l}\text { Patterned } \\
\text { ground } \\
\text { features }\end{array}$} & \multirow{2}{*}{$\begin{array}{l}\text { Height of } \\
\text { micro- } \\
\text { relief } \\
\text { features } \\
\end{array}$} & \multirow{2}{*}{$\begin{array}{l}\text { Lateral dimensions } \\
\text { of parterned. } \\
\text { ground features }\end{array}$} & \multirow{2}{*}{$\begin{array}{l}\text { Slope } \\
\text { and } \\
\text { aspect }\end{array}$} & \multirow[b]{2}{*}{$\begin{array}{c}\text { Site } \\
\text { moisture* }\end{array}$} & \multirow[b]{2}{*}{$\begin{array}{l}\text { Depth of } \\
\text { thaw }(\mathrm{cm})^{\dagger}\end{array}$} & \multicolumn{3}{|c|}{ Soil description } & \multirow[b]{2}{*}{ Plant community classifleation "* } \\
\hline & & & & & & & & Horizon & $\mathrm{pH}$ & $\begin{array}{l}\text { Classification } \\
\text { (profle no.) }\end{array}$ & \\
\hline $\begin{array}{l}\text { West Dock } \\
\text { Mesic } \\
\text { Am }\end{array}$ & $\begin{array}{l}\text { Drained take } \\
\text { basin }\end{array}$ & $\begin{array}{l}\text { low-centered } \\
\text { polygon }\end{array}$ & $\begin{array}{l}\text { Rim-center } \\
\text { contrast: } \\
5-15 \mathrm{~cm}\end{array}$ & $\begin{array}{l}10 \times 15 \mathrm{~m} \\
\text { polygon }\end{array}$ & 0 & 6 & 11 & $\begin{array}{l}\text { Oi } 1 \\
\text { Oi } 2 \\
\text { C } 1\end{array}$ & $\begin{array}{l}5.70-5.75 \\
5.25-5.35 \\
5.45-5.50\end{array}$ & $\begin{array}{l}\text { Pergelic } \\
\text { Cryaquept } \\
\text { (PRD 422 U4) }\end{array}$ & $\begin{array}{l}\text { U } 4 \text { MOIST Carex aqua ritis, } \\
\text { Salix arctica, Drepanocladus } \\
\text { revolvens GRAMINOID MEADOW }\end{array}$ \\
\hline $\begin{array}{l}\text { West Dock } \\
\text { Wet } \\
\text { Aw }\end{array}$ & $\begin{array}{l}\text { Drained lake } \\
\text { basin, area } \\
\text { of seawater } \\
\text { inundation }\end{array}$ & $\begin{array}{l}\text { aligned } \\
\text { hummocks }\end{array}$ & $\sim 10 \mathrm{~cm}$ & - & 0 & 8 & 25 & $\begin{array}{l}\text { Oe } 1 \\
\text { Oe } 2 \\
\text { Oe } 3\end{array}$ & $\begin{array}{l}7.55-7.60 \\
6.10-6.20 \\
5.20-5.25\end{array}$ & $\begin{array}{l}\text { Histic } \\
\text { Pergelic } \\
\text { Cryaquept } \\
\text { (PRD 401 WDB) }\end{array}$ & $\begin{array}{l}\text { M } 9 \text { WET Carex subspathacea } \\
\text { GRAMINOID MEADOW }\end{array}$ \\
\hline $\begin{array}{l}\text { Compressor } \\
\text { Plant } \\
\text { Dry } \\
\text { Bd }\end{array}$ & $\begin{array}{l}\text { Old river } \\
\text { terrace, now } \\
\text { a coastal } \\
\text { bluff }\end{array}$ & $\begin{array}{l}\text { Reticulate } \\
\text { ground, } \\
\text { low hummocks; } \\
\text { some stripes }\end{array}$ & $2-5 \mathrm{~cm}$ & $\begin{array}{l}25-30 \mathrm{~cm} \\
\text { diameter } \\
\text { hummocks }\end{array}$ & $\begin{array}{l}2^{\circ} \\
\text { ssw }\end{array}$ & 2 & 28 & $\begin{array}{l}\text { A } 1 \\
\text { B } 2 \\
C_{1} 1\end{array}$ & $\overline{-}$ & $\begin{array}{l}\text { Pergelic } \\
\text { Cryaquept } \\
\text { (PRD } 400 \mathrm{CP} \text { ) }\end{array}$ & $\begin{array}{l}\text { B } 11 \text { DRY Dryas integrifolia, Sedum } \\
\text { rosea, Artemista borealis, Salix } \\
\text { ovalifolla PROSTRATE SCRUB }\end{array}$ \\
\hline $\begin{array}{l}\text { Drill Site } \\
\text { No. } 2 \\
\text { Mesic } \\
\text { Cm }\end{array}$ & $\begin{array}{l}\text { Drained lake } \\
\text { basin }\end{array}$ & $\begin{array}{l}\text { low-centered } \\
\text { polygon }\end{array}$ & $\begin{array}{l}\text { Rim-center } \\
\text { contrast: } \\
15 \mathrm{~cm}\end{array}$ & $\begin{array}{l}7-8 \mathrm{~m} \\
\text { diameter } \\
\text { polygon }\end{array}$ & 0 & 5 & 27 & $\begin{array}{l}\text { A } 1 \\
\text { A } 12 \\
\text { A12/IIC1 } \\
\text { III A1b }\end{array}$ & $\begin{array}{l}8.25-8.30 \\
7.80-7.95 \\
8.00-8.10 \\
8.10-8.20\end{array}$ & $\begin{array}{l}\text { Pergelic } \\
\text { Cryaquept } \\
\text { (PRD 407 D52A1) }\end{array}$ & $\begin{array}{l}\text { U } 3 \text { MOIST Eriophorum } \\
\text { angustifotium, Dryas integrifolia, } \\
\text { Tomenthypnum nitens, Thamnolia } \\
\text { subuliformis GRAMINOID MEADOW }\end{array}$ \\
\hline $\begin{array}{l}\text { Drill Site } \\
\text { No. } 2 \\
\text { Wet } \\
\text { Cw }\end{array}$ & $\begin{array}{l}\text { Drained lake } \\
\text { basin }\end{array}$ & $\begin{array}{l}\text { non patterned } \\
\text { pond margin }\end{array}$ & $0-5 \mathrm{~cm}$ & $\begin{array}{l}\text { pond margin } \\
15 \mathrm{~m} \\
\text { wide }\end{array}$ & 0 & 8 & 21 & $\begin{array}{l}\text { Oi } 1 \\
\text { LOC } 1 \\
\text { IICL/ } \\
\text { LOC } 2\end{array}$ & $\begin{array}{l}7.85-7.95 \\
8.00 \\
8.00 \\
7.90-7.95\end{array}$ & $\begin{array}{l}\text { Pergelic } \\
\text { Cryaquept } \\
\text { (PRD 409 D52B) }\end{array}$ & $\begin{array}{l}\text { M } 2 \text { WET Carex aquatilis, } \\
\text { Drepanocladus revolvens, } \\
\text { Cinclidium latifolium } \\
\text { GRAMINOID MEADOW }\end{array}$ \\
\hline $\begin{array}{l}\text { Gravel Pit } \\
\text { Dry } \\
\text { Dd }\end{array}$ & $\begin{array}{l}\text { Old river: } \\
\text { terrace, now } \\
\text { a low ridge }\end{array}$ & $\begin{array}{l}\text { reticulate } \\
\text { ground, } \\
\text { low hummocks }\end{array}$ & $5-10 \mathrm{~cm}$ & $\begin{array}{l}15-20 \mathrm{~cm} \\
\text { diameter } \\
\text { hummocks }\end{array}$ & $\begin{array}{l}2-3^{\circ} \\
\mathrm{SE}\end{array}$ & 3 & 40 & $\begin{array}{ll}A & 1 \\
A & 12 \\
A & 13\end{array}$ & $\begin{array}{l}8.15-8.40 \\
8.30-8.40 \\
8.40-8.45\end{array}$ & $\begin{array}{l}\text { Pergelic } \\
\text { Cryoboroll } \\
\text { (PBR 404 GP) }\end{array}$ & $\begin{array}{l}\text { B I DRY Dryas integrifolia, Carex } \\
\text { mupestris, Lecanora epibryon, } \\
\text { Ditrichum Rexicaule } \\
\text { PROSTRATE SCRUB }\end{array}$ \\
\hline $\begin{array}{l}\text { Pad } \mathbf{F} \\
\text { Mesic } \\
\text { Em }\end{array}$ & $\begin{array}{l}\text { Drained lake } \\
\text { basin }\end{array}$ & $\begin{array}{l}\text { low-centered } \\
\text { polygon }\end{array}$ & $\begin{array}{l}\text { Rim-eenter } \\
\text { contrast: } \\
15-20 \mathrm{~cm}\end{array}$ & $\begin{array}{l}10 \times 10 \mathrm{~m} \\
\text { polygon }\end{array}$ & 0 & 5 & 12 & $\begin{array}{l}\mathrm{Oi} \\
\mathrm{Oe}\end{array}$ & - & $\begin{array}{l}\text { Pergelic } \\
\text { Cryaquept }\end{array}$ & $\begin{array}{l}\text { U I MOIST Carex blgelowil, } \\
\text { Salix pulchra, Dryas integrifolla, } \\
\text { Tomenthypnum nitens, Oncophonus } \\
\text { wahlenbergii GRAMINOID MEADOW }\end{array}$ \\
\hline $\begin{array}{l}\text { Pad F } \\
\text { Wet } \\
\text { Ew }\end{array}$ & $\begin{array}{l}\text { Drained lake } \\
\text { basin }\end{array}$ & $\begin{array}{l}\text { nonpatterned } \\
\text { ground, re- } \\
\text { cently drained } \\
\text { pond (?) }\end{array}$ & $\sim 3 \mathrm{~cm}$ & $\begin{array}{l}20 \times 100 \mathrm{~m} \\
\text { basin }\end{array}$ & 0 & 8 & 27 & $\begin{array}{l}\text { Oe } 1 \\
\text { Oe } 2 \\
\text { C } 1\end{array}$ & $\begin{array}{l}5.75-5.90 \\
5.80 \\
6.15-6.30\end{array}$ & $\begin{array}{l}\text { Pergelic } \\
\text { Cryaquept } \\
\text { (PRD 420 EW) }\end{array}$ & $\begin{array}{l}\text { M } 1 \text { WET Carex aquatilis, } \\
\text { Saxifraga foliolosa, Drepano. } \\
\text { cladus lycopodioides var } \\
\text { brevifotius GRAMINOID MEADOW }\end{array}$ \\
\hline
\end{tabular}

-1-10: Very dry, to deep standing water.

+17 July 1980.

.. Walker et al. 1980 . 
wetted and placed so that they extracted soil solution $4 \mathrm{~cm}$ below the surface; the large, prewetted cylinders were positioned in the deeper horizons. A hole slightly less than the diameter of the lysimeter was made to the desired depth near but outside each experimental plot (Fig. 2). The lysimeter was placed in the hole, and bentonite grout was placed around the stoppered top at the level of the soil surface to prevent fluid from flowing down the sides of the lysimeter.

\section{Prespill assessment}

Each site was described in terms of its landform, surface features, moisture, temperature and exposure to wind and snow (Table 1). Soil profiles were described, and soil samples were collected for determining $\mathrm{pH}$ and organic carbon content. The depth of thaw at each site was measured on the day of the spill. Each plot was photographed with infrared film.

One or two days before the spill, a vacuum (about $70 \mathrm{psi}$ ) was applied to each of the larger suction lysimeters. Soil-solution samples of 10-70
$\mathrm{mL}$ were extracted 24 hours later. The shallow cylinders were also evacuated, but because they were much more porous than the larger ones, the sample return was immediate. The temperature-compensated conductivities of all samples were measured in $\mu \mathrm{mhos} / \mathrm{cm}$ on a bridge-type conductivity meter. These values constitute the prespill controls. Some of the lysimeters in the mesic sites returned no prespill samples because the soil moisture was bound too tightly to the sapric organic matter. No prespill samples were obtained from the two sites in dry tundra.

The composition and vigor of each plot's vegetation were described in detail. A list of the plants is given in the Appendix. Cover values for all of the vascular plants and the dominant bryophytes and lichens were visually estimated. Cover values report the percentage of a plot's area covered by each taxon in a vertical projection of the foliage upon the ground (Shimwell 1971). "Total vegetative cover," the sum of the cover values for all taxa in the plot, may exceed $100 \%$. For plants that retain their dead leaves from one year to the next,

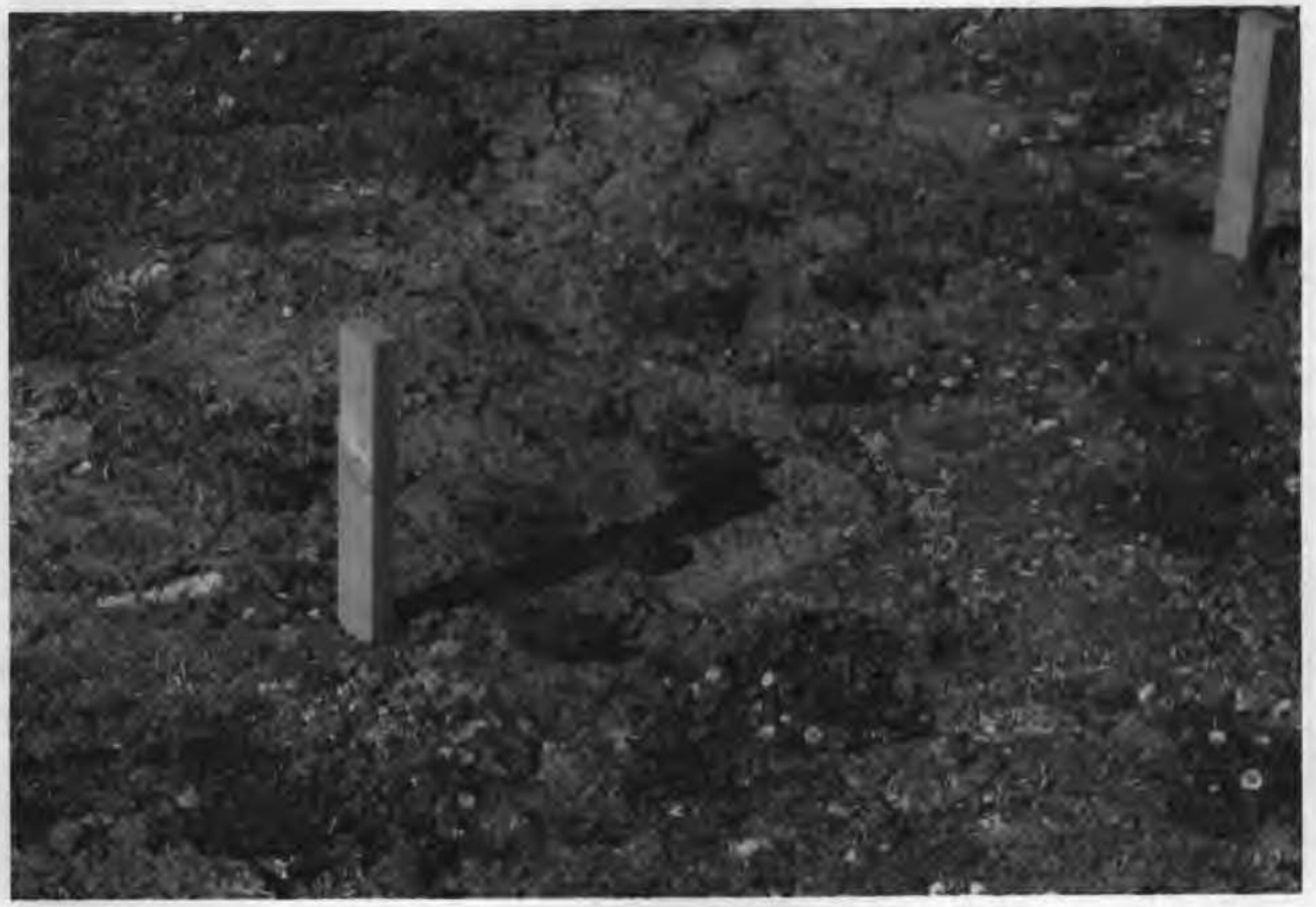

a. Vegetation at the Compressor Plant dry site. The dominant plants are Dryas integrifolia, Sedum rosea, Artemisia borealis and Salix ovalifolia. (Photo by Sue Degler.)

Figure 5. Vegetation at three sites. 


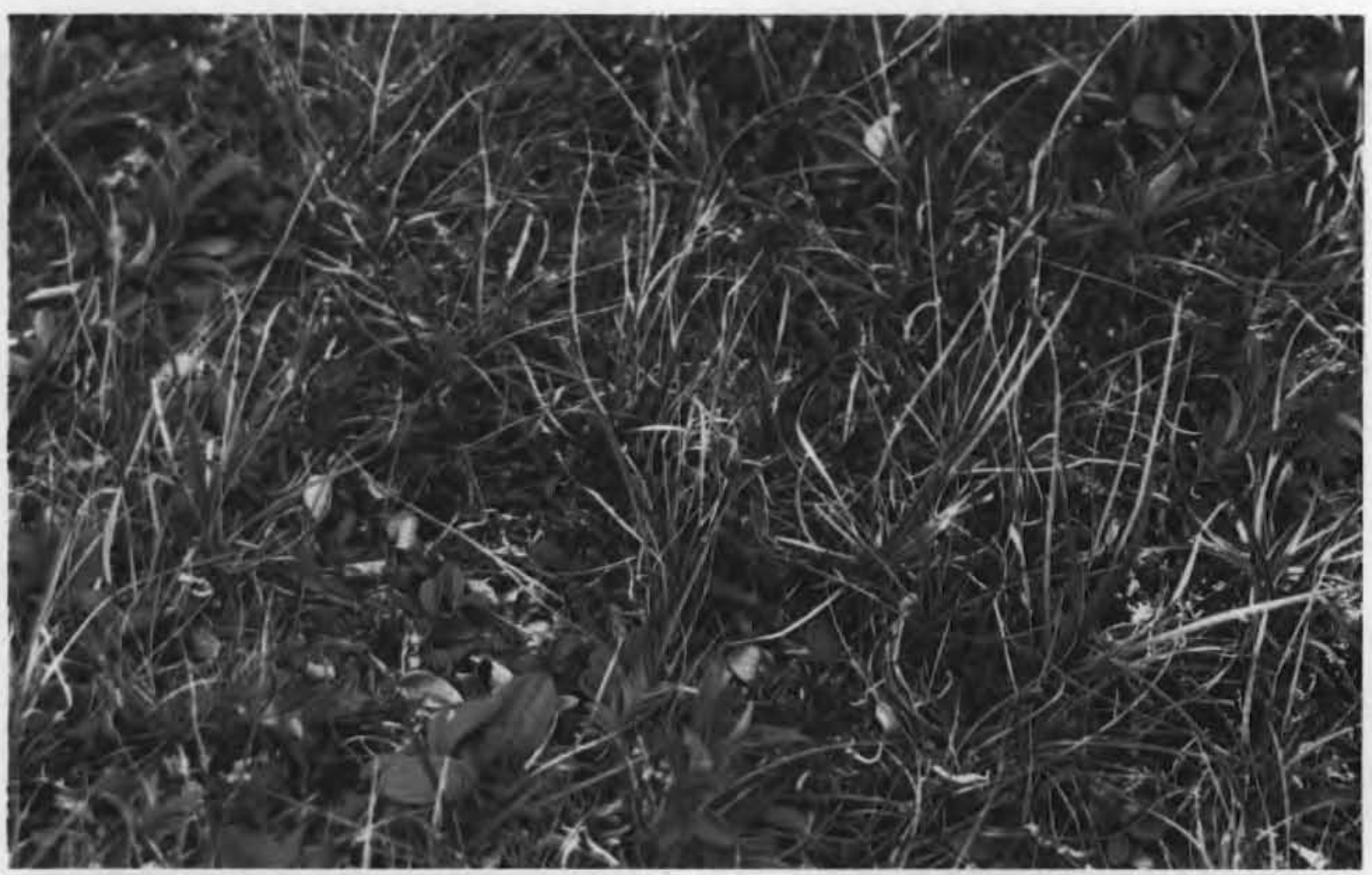

b. Vegetation at the Pad F mesic site. The dominant plants are Carex bigelowii, Salix pulchra, Dryas integrifolia, Tomenthypnum nitens and Oncophor us wahlenbergii. (Photo by Sue Degler.)

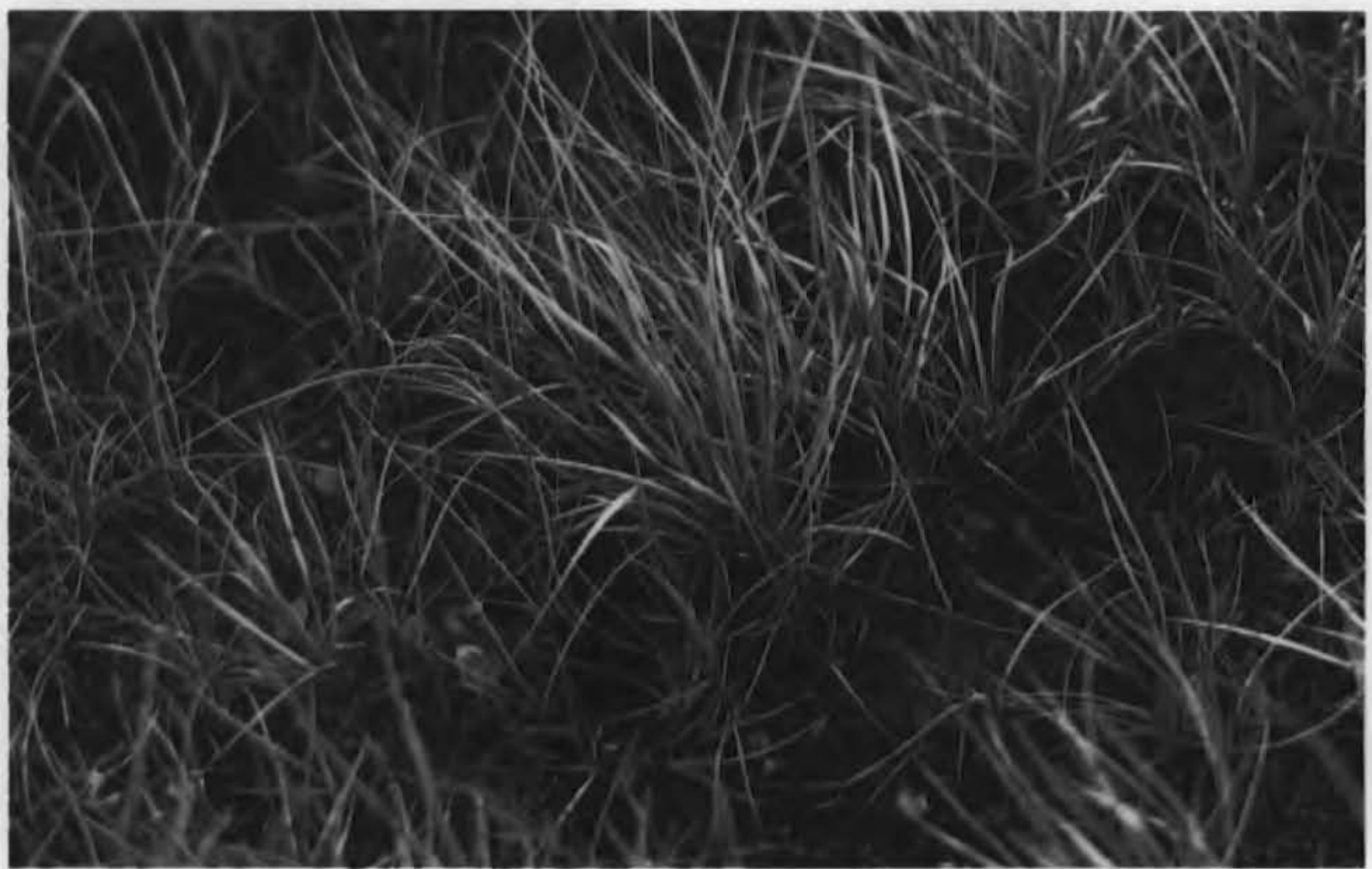

c. Vegetation at the Pad F wet site. The dominant plants are Carex aquatilis and Drepanocladus lycopodioides var. brevifolius. (Photo by Sue Degler.)

Figure 5 (cont'd). Vegetation at three sites. 


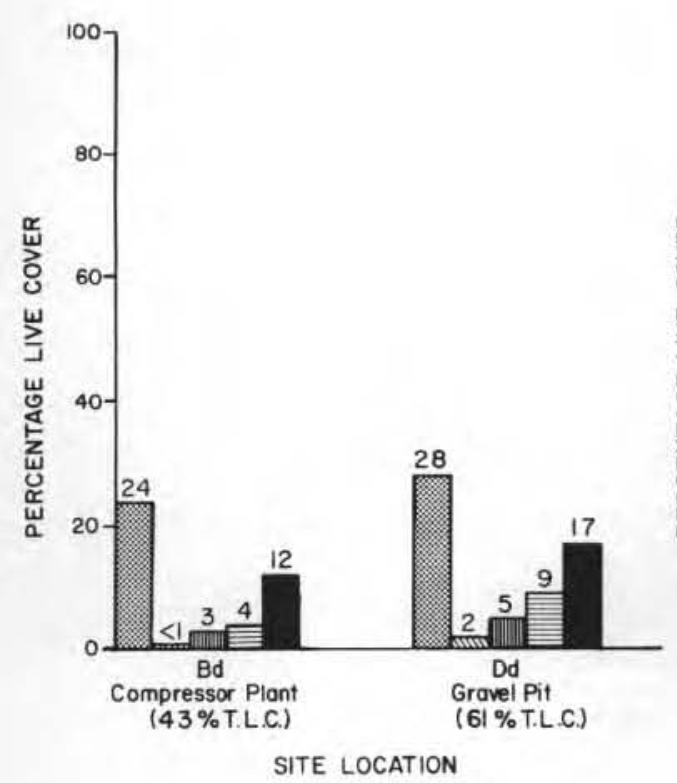

a. Dry sites.

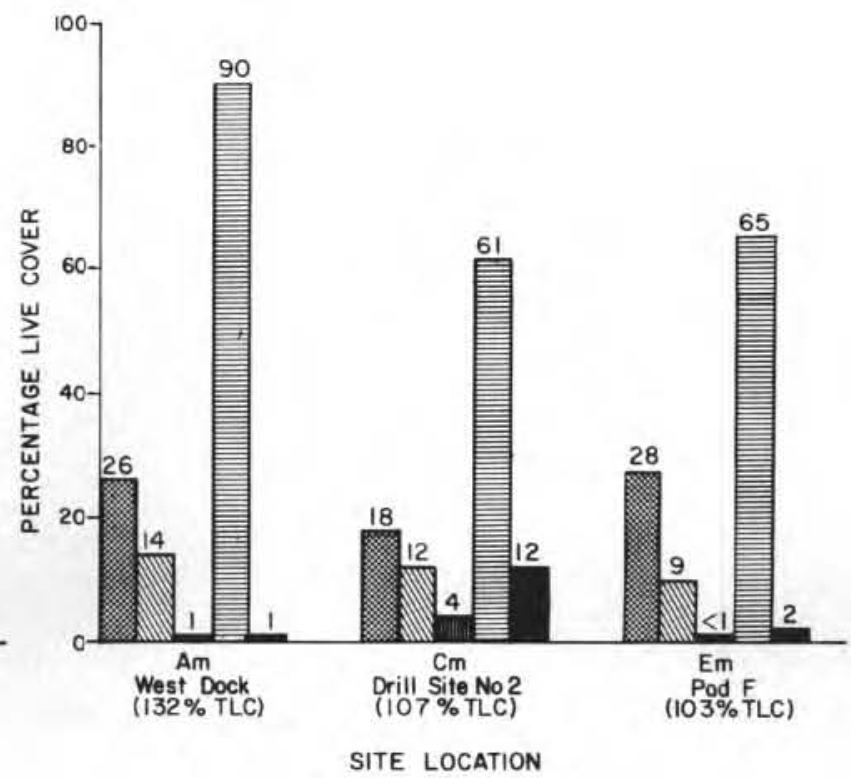

b. Mesic sites.

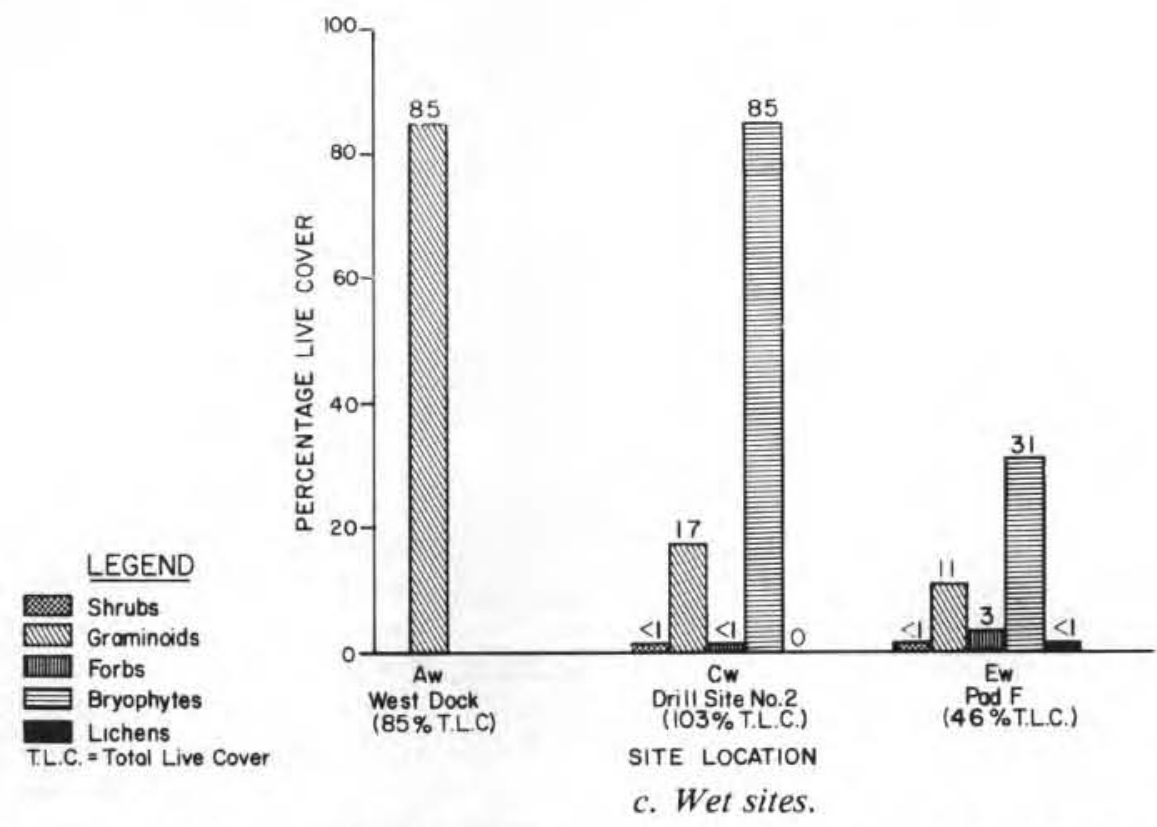

Figure 6. Plant community composition by growth form before the spill.

such as Dryas integrifolia ssp. integrifolia and some of the graminoids, separate cover values were recorded for live foliage and standing-dead foliage. The live-to-dead ratio of the combined moss taxa was similarly indicated. The prevalent phenological stage of each vascular plant population was recorded, and numbers of individuals of selected taxa were counted to allow long-term monitoring of the responses of individual plants. To provide a basis for a broad comparison of the plant communities at the eight sites, the abun- dance of different vegetation growth forms was evaluated. Cover values were determined for each of five growth forms: shrub, graminoid, forb, bryophyte and lichen (Figs. 5 and 6 ).

\section{Seawater application}

Seawater was obtained from Prudhoe Bay at the West Dock extension and delivered by a Rolligon off-road vehicle to the various sites. The temperature-compensated conductivity of the seawater, measured on a bridge, was $46,008 \mu \mathrm{mhos} / \mathrm{cm}$ 
Table 2. Duration of the seawater application and the area covered by the seawater at each location.

\begin{tabular}{|c|c|c|c|c|c|c|}
\hline $\begin{array}{c}\text { Map } \\
\text { designation }\end{array}$ & Site & $\begin{array}{l}\text { Moisture } \\
\text { category }\end{array}$ & $\begin{array}{l}\text { Spill pertod } \\
\text { (min) }\end{array}$ & $\begin{array}{c}\text { Approximate ared } \\
\text { covered }\left(\mathrm{m}^{2}\right)\end{array}$ & $\begin{array}{l}\text { Approximate } \\
\text { duration of } \\
\text { standing water }\end{array}$ & $\begin{array}{l}\text { Approximate } \\
\text { duration of } \\
\text { soil seturation }\end{array}$ \\
\hline Am & West Dock & Mesic & 12 & 140 & One hour & One day \\
\hline Aw & West Dock & Wet & 11 & 70 & One day & Continuous \\
\hline Bd & $\begin{array}{l}\text { Compressor } \\
\text { Plant }\end{array}$ & Dry & 11 & 40 & $<10 \mathrm{~min}$ & $<15 \mathrm{~min}$ \\
\hline $\mathrm{Cm}$ & $\begin{array}{l}\text { Drill Site } \\
\text { No. } 2\end{array}$ & Mesic & 11 & 90 & One hour & One day \\
\hline $\mathrm{Cw}$ & $\begin{array}{l}\text { Drill Site } \\
\text { No. } 2\end{array}$ & Wet & 10 & 90 & One day & Continuous \\
\hline Dd & Gravel Pit & Dry & tt & 50 & $<10 \mathrm{~min}$ & $<15 \min$ \\
\hline Em & Pad F & Mesic & 10 & 110 & One hour & One day \\
\hline Ew & $\operatorname{Pad} F$ & Wet & 9 & Undetermined & One day & Continuous \\
\hline
\end{tabular}

$(29,445 \mathrm{ppm})$. This value is in the upper range of summer salinity values reported for Prudhoe Bay seawater (U.S. Army Corps of Engineers 1980). The seawater at $3.5^{\circ} \mathrm{C}$ was applied to all of the experimental plots in the afternoon and evening of 17 July. There was no precipitation on the spill date or for two days before and three days after the spill. A seawater sample was collected and subsequently analyzed for $\mathrm{Na}^{+}, \mathrm{K}^{+}, \mathrm{Mg}^{++}$and $\mathrm{Ca}^{+*}$. Except for $\mathrm{Ca}^{+*}$, the ion concentrations were comparable to those of standard seawater (Krauskopf 1967). The higher $\mathrm{Ca}^{+*}$ concentration is probably due to limestone parent material in the Prudhoe Bay drainage area.

Approximately $2000 \mathrm{~L}$ of seawater was applied to each experimental site through a 7-cm-diameter hose. To reduce the physical impact of the water stream on the soil surface, the hose was positioned on a sheet of plywood placed flush with the front stakes of the $0.5-\mathrm{m}$ plot (Figs, 2 and 3). Application of the water required approximately $11 \mathrm{~min}$ utes. When the application was complete, a diagram of the area covered by the spill was drawn, and stakes were placed along the periphery of the spill. The length of time required for all of the applied water to penetrate the soil was estimated.

At most of the sites all three experimental plots were inundated by the seawater. At the dry sites, however, the water tended to run along the cracks in the hummocky ground, leaving some of the hummocks in the $3.5-\mathrm{m}$ plots dry or only slightly moistened. The water penetrated the soil at these sites almost immediately, and the surface was saturated for less than 15 minutes. At the mesic sites the polygon rims tended to restrict the sea- water to the polygon basins. The moist soil prevented the seawater from penetrating rapidly, causing it to pond within the polygon rims. Puddles remained at all the mesic sites upon final observation (up to an hour after each spill). The following morning the soil at these sites still appeared to be saturated, but no standing water remained. Although the wet sites did not have standing water before the spill, the wet surfaces and saturated soil made it difficult to determine the extent of the seawater coverage in these areas. All of the plots appeared to receive some seawater. All three wet sites contained small, shallow areas of standing water on the day after the spill, Table 2 summarizes the duration of standing water and soil saturation at each of the study locations.

\section{Postspill assessment}

The plots were observed frequently for 28 days following the spill. The condition of the vegetation was visually assessed. To aid in interpreting plant responses, color photographs were taken of plants in apparent full health, untreated plants that were judged to be senescing naturally, and plants that had developed treatment-induced symptoms. Each plot was also photographed in color at the end of the 28 days.

Symptoms of physiological stress attributable to the seawater treatment were first observed in plants in the experimental plots on 25 July 1980 , eight days after the spill. The kinds and extent of the symptoms were recorded. For the three days following the spill, each plot was observed. The symptoms developed by each plant taxon, the ex- 
tent of the symptoms within the plot, and the degree to which individual plants were affected were recorded. These observations were repeated on 4 August and 18 August.

Soil-solution samples were collected immediately after the spill and on 18 July, 26 July and 14 August. Nearly all of the lysimeters were heavily damaged by foxes and eventually rendered inoperable.

The study sites were revisited five times between late May and mid-August 1981. Each plant taxon was observed in detail in early and mid-July; these observations form the basis for the formal 1981 vegetation evaluation. Briefer, more general observations were made on the other occasions, and these have contributed to the interpretation of the July data. Each plot was photographed in color in mid-July as well as on other occasions. Soil-solution samples were collected in mid-July for comparison with the 1980 samples.

\section{Enzyme assay and analysis of soll flora}

For each plot in the mesic sites, three samples were collected from the top $10 \mathrm{~cm}$ of soil in July 1981. The samples were placed in plastic bags, frozen and shipped to the laboratory. They were kept frozen until they could be processed for enzyme assaying, using methods described by Linkins et al. (1978) and Linkins and Neal (1982). Because of time limitations, only the mesic sites were sampled.

Both the exo- and endocellulase components of the cellulase complex were measured on soil suspensions as described by Linkins and Neal (in press) without adding salt or buffer solutions to the soil-water suspension. Soil phosphomonoesterase was measured using the method of Herbein (1981),

Ectomycorrhizal root samples of Salix arctica, $S$. reticulata $\mathrm{ssp}$, reticulata and $S$. rotundifolia ssp. rotundifolia were collected in July 1981 from the mesic plots. They were processed for determining the respiration rate using methods described by Linkins and Antibus (1978), Root respiration rates were measured at $10^{\circ} \mathrm{C}$ within 24 hours of collection, either by direct $\mathrm{O}_{2}$ measurements using a Gilson Differential Respirometer or an Orbisphere oxygen electrode. Soil respiration rates were measured at $10^{\circ} \mathrm{C}$ using direct measurement techniques with a Gilson Differential Respirometer (Linkins et al. 1978), Ectomycorrhizal root-tip enumeration and viability were estimated as described by Antibus and Linkins (1978) and Linkins and Antibus (1982b).
All data are expressed as the mean value of 18 measurements: two measurements were made on each of three soil subsamples from each of three replicate soil samples from each plot. All values expressed as significant are at the 0.001 level unless otherwise stated.

\section{RESULTS AND DISCUSSION}

\section{Soil-solution conductivities}

The prespill soil-solution conductivities were about the same for all sites from which soil solution could be extracted except the wet site at West Dock (Table 3). Immediately after the spill the soil-solution conductivity near the surface (the upper $4 \mathrm{~cm}$ ) at the wet sites approached that of seawater. Over the next 24 hours the conductivities dropped considerably due to dilution and/or movement of water from the site. Further reductions in conductivity apparently occurred at a relatively constant rate, and the prespill values were approached within about 30 days (Tables 3 and 4 ).

The soil solutions extracted from the deeper lysimeters at the same sites showed a delayed response. For the most part the conductivities did not indicate a significant increase in salt concentration within 24 hours. Over the 30 days of record in 1980 they either showed no significant change (wet site, Pad F) or showed a slow, apparently constant increase.

The course of events at a particular site depended on the degree of saturation at the time of the spill, the residence time of the seawater, and the soil texture. The limited data from the wet sites suggest that shallow-rooted species, such as Saxifraga hirculus, may be subjected to much higher salt concentrations than deep-rooted plants, such as Eriophorum angustifolium. At the dry sitesthe escarpment at the Compressor Plant and the ridge at the Gravel Pit-the soils were sandy and unsaturated. The seawater moved rapidly downward-so rapidly, in fact, that the shallow lysimeters returned no solution unless pumped immediately after the spill. For samples obtained under these conditions the conductivity was close to that of the seawater. The deeper lysimeters continued to yield solutions with very high conductivities up to 30 days after the spill. In these cases, where flushing action was probably slight, salt concentrations remained high for an extended period.

For the wet sites the 1981 data support the 1980 conclusion that after a seawater spill of about 30 $\mathrm{L} / \mathrm{m}^{2}$ the soil-solution conductivity returns to prespill levels in about 30 days. In wet areas both the 
Table 3. Soil-solution conductivities at the spill sites.

\begin{tabular}{|c|c|c|c|c|c|c|c|c|c|c|}
\hline \multirow{3}{*}{ Site } & \multirow{3}{*}{$\begin{array}{l}\text { Moisfure } \\
\text { category }\end{array}$} & \multirow{3}{*}{$\begin{array}{l}\text { Distance from } \\
\text { spill point } \\
(m)\end{array}$} & \multirow{3}{*}{$\begin{array}{l}\text { Depth } \\
(\mathrm{cm})\end{array}$} & \multicolumn{7}{|c|}{ Conductivity $(\mu \mathrm{mho} / \mathrm{cm})$} \\
\hline & & & & \multicolumn{2}{|c|}{ Prespill } & \multicolumn{5}{|c|}{ Postspill } \\
\hline & & & & $7 / 16 / 80$ & $7 / 17 / 80$ & $7 / 17 / 80$ & $7 / 18 / 80$ & $7 / 26 / 80$ & $8 / 14 / 80$ & $7 / 18 / 81$ \\
\hline Seawater (spill) & & & - & - & - & 46,008 & - & - & - & - \\
\hline \multicolumn{3}{|c|}{ Drinking water (NANA Camp, Deadhorse) } & - & - & - & - & - & 267 & - & - \\
\hline West Dock & Mesic & Control & $1-5$ & - & - & - & - & - & - & 1,263 \\
\hline \multirow[t]{5}{*}{ Am } & & Control & $19-20$ & - & - & - & - & - & - & 1,017 \\
\hline & & 0.5 & $1-5$ & 1,324 & - & - & 25,952 & NR & $d^{\dagger}$ & 1,263 \\
\hline & & 3.5 & $1-5$ & $N R *$ & NR & - & 16,487 & 17,068 & 8,153 & 1,017 \\
\hline & & 3.5 & $13-14$ & NR & NR & - & 1,320 & 2,764 & d & 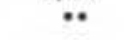 \\
\hline & & Surface water & - & - & - & - & - & - & 11,815 & $\cdots$ \\
\hline \multirow{6}{*}{$\begin{array}{l}\text { West Dock } \\
\text { Aw }\end{array}$} & Wet & Control & $1-5$ & - & - & - & - & - & - & 9,718 \\
\hline & & 0.5 & $1-5$ & - & 18,400 & 37,855 & - & 36,202 & 19,814 & 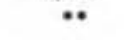 \\
\hline & & 0.5 & $22-23$ & - & 18,747 & - & d & 24,996 & d & $*$ \\
\hline & & 3.5 & $1-5$ & - & - & - & - & - & - & 11,407 \\
\hline & & 3.5 & $22-23$ & 12,829 & 12,550 & d & - & - & - & 14,371 \\
\hline & & Surface water & - & - & - & - & - & - & - & 10,165 \\
\hline \multirow{5}{*}{$\begin{array}{l}\text { Compressor Plant } \\
\text { Bd }\end{array}$} & Dry & Control+† & 10 & - & - & - & - & - & - & $<100$ \\
\hline & & 0.5 & $1-5$ & NR & NR & 42,048 & NR & NR & d & 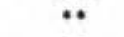 \\
\hline & & 3.5 & $1-5$ & NR & NR & NR & NR & NR & d & $\cdots$ \\
\hline & & $3.5+t$ & 10 & - & - & - & - & - & - & 2,285 \\
\hline & & 3.5 & $22-23$ & NRR & NR & NR & 22,502 & 30.077 & d & $\cdots$ \\
\hline \multirow{4}{*}{$\begin{array}{l}\text { Drill Site No. } 2 \\
\mathrm{Cm}\end{array}$} & Mesic & Control & $19-20$ & - & - & - & - & - & - & 763 \\
\hline & & 0.5 & $13-14$ & - & 440 & - & 810 & 1,114 & 8,034 & *. \\
\hline & & 0.5 & $18-19$ & NR & - & - & 466 & 605 & - & $\cdots$ \\
\hline & & 3.5 & $18-19$ & - & 606 & - & 458 & 1,527 & 3,872 & $3,470 * \cdots$ \\
\hline \multirow{7}{*}{$\begin{array}{l}\text { Drill Site No. } 2 \\
\mathrm{Cw}\end{array}$} & Wet & Control & $1-5$ & - & - & - & - & - & - & 815 \\
\hline & & Control & $19-20$ & - & - & - & - & - & - & 1,199 \\
\hline & & 0.5 & $1-5$ & 1,085 & - & - & 13,629 & 12,631 & 2,751 & * \\
\hline & & 0.5 & $22-23$ & - & 1,165 & - & 1,315 & 3,059 & d & 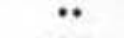 \\
\hline & & 3.5 & $1-5$ & 1,013 & - & - & 14,994 & 12,939 & 2,946 & 1,068 \\
\hline & & 3.5 & $19-20$ & - & - & - & - & - & - & 902 \\
\hline & & Surface water & - & - & - & - & - & - & 2,405 & 918 \\
\hline \multirow{5}{*}{$\begin{array}{l}\text { Gravel Pit } \\
\text { Dd }\end{array}$} & Dry & Controlt† & 10 & - & - & - & - & - & - & $<100$ \\
\hline & & 0.5 & $1-5$ & NR & NR & NR & NR & NR & NR & 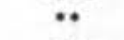 \\
\hline & & 3.5 & $1-5$ & NR & NR & NR & NR & NR & d & $\cdots$ \\
\hline & & $3.5+t$ & 10 & - & - & - & - & - & - & 1,432 \\
\hline & & 3.5 & $22-23$ & NR & NR & NR & 13,097 & 18,429 & 14,526 & 24.295 \\
\hline \multirow{5}{*}{$\begin{array}{l}\text { Pad F } \\
\text { Em }\end{array}$} & Mesic & Control & $19-20$ & - & - & - & - & - & - & $<100$ \\
\hline & & 0.5 & $1-5$ & 1,403 & - & - & 19,763 & 15,715 & d & $\cdots$ \\
\hline & & 0.5 & $13-14$ & NR & NR & - & 4,070 & 1,148 & d & 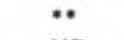 \\
\hline & & 3.5 & $1-5$ & - & - & - & - & - & - & NR \\
\hline & & 3.5 & $13-14$ & NR & NR & - & 6,494 & 2,155 & d & 2,218 \\
\hline \multirow{5}{*}{$\begin{array}{l}\text { Pad } F \\
\text { Ew }\end{array}$} & Wet & Control & $19-20$ & - & - & - & - & - & - & 2,148 \\
\hline & & 0.5 & $22-23$ & - & 1,075 & - & 1,172 & 1,106 & d & * \\
\hline & & 3.5 & $1-5$ & - & - & - & 2,949 & 9,027 & 2,370 & 1,880 \\
\hline & & 3.5 & $22-23$ & - & 868 & - & 825 & 886 & d & 1,343 \\
\hline & & Surface water & - & - & - & - & - & - & 1,112 & 1,660 \\
\hline
\end{tabular}

- No return of sample.

† Lysimeter destroyed.

* Lysimeter not installed in 1981.

†† Analysis preformed on leachate ( $100 \mathrm{~g}$ of soil per

$100 \mathrm{~mL}$ of triple-distilled, demineralized water).

*. Second analysis on $8 / 27 / 81$ showed $1,988 \mu \mathrm{mho} / \mathrm{cm}$. 
Table 4. Prespill and postspill ion concentrations in two study plots.

\begin{tabular}{|c|c|c|c|c|c|c|}
\hline \multirow{2}{*}{$\begin{array}{l}\text { Depth } \\
(\mathrm{cm})\end{array}$} & \multirow{2}{*}{$\begin{array}{c}\text { Disfance } \\
\text { from } \\
\text { spill point }(m)\end{array}$} & \multirow[b]{2}{*}{ Date } & \multicolumn{4}{|c|}{ Concentration $(\mu \mathrm{g} / \mathrm{mL})$} \\
\hline & & & $\mathrm{Ca}$ & $M g$ & $\underline{K}$ & $\mathrm{Na}$ \\
\hline \multicolumn{7}{|c|}{ Pad F (wet) } \\
\hline 19 & 3.5 & $\begin{array}{l}17 \text { July } 1980 \\
\text { (prespill) }\end{array}$ & 82 & 12 & 4 & $220 \pm 150$ \\
\hline $4-8$ & 3.5 & 18 July 1980 & 210 & 28 & 3 & $550 \pm 150$ \\
\hline $4-8$ & 3,5 & 26 July 1980 & 375 & 108 & 27 & $1,380 \pm 150$ \\
\hline $4-8$ & 3.5 & 15 Aug 1980 & 95 & 30 & 6 & $520 \pm 150$ \\
\hline \multicolumn{7}{|c|}{ West Dock (wet) } \\
\hline 19 & 0.5 & $\begin{array}{l}17 \text { July } 1980 \\
\text { (prespill) }\end{array}$ & 500 & 370 & 102 & $3,020 \pm 150$ \\
\hline $4-8$ & 0.5 & 26 July 1980 & 510 & 550 & 216 & $1,590 \pm 150$ \\
\hline $4-8$ & 0.5 & 15 Aug 1980 & 395 & 375 & 132 & $3,620 \neq 150$ \\
\hline & & & \multicolumn{4}{|c|}{ Spill water } \\
\hline & & & 620 & 1,275 & 430 & 9,000 \\
\hline & & & \multicolumn{4}{|c|}{ Standard seawater (Krauskopf 1967) } \\
\hline & & & 400 & 1,350 & 380 & 10,500 \\
\hline
\end{tabular}

near-surface and subsurface soil is apparently completely flushed. Holdover effects in these sites do not appear to be of concern.

The situation in mesic and dry sites appears to be quite different. In these areas the salts moved deeper into the soil, apparently concentrating at or near the seasonal thaw line. Conductivity levels at $20 \mathrm{~cm}$ in 1981 were approximately as they were in 1980 except in the Gravel Pit dry site, where the 1981 conductivity value at $30 \mathrm{~cm}$ was nearly twice that measured at a similar depth in 1980. (The remaining suction lysimeters in the dry sites returned no soil solution.) This may be explained by long. term leaching of salts, which were initially retained in the upper part of the soil, by snow meltwater and precipitation. Because the sandy soils at dry sites normally do not retain water at low suction pressures after the thaw front passes, a leaching experiment was conducted on soil material taken from $10 \mathrm{~cm}$ to provide an estimate of the amount of salt retained in the soil. Conductivity levels of the leachate from $100 \mathrm{~mL}$ of tripledistilled, demineralized water leached through 100 $\mathrm{g}$ of soil were measured (Table 3). These data, although somewhat qualitative, support the idea that salts are retained within the profile. A similar situation probably prevails, but to a lesser extent, at the mesic sites. In the absence of a hydraulic gradient, brine may concentrate at the interface of the active layer and the permafrost and may increase the normal seasonal thaw. The $40 \%$ decrease in conductivity at $20 \mathrm{~cm}$ in the mesic site at Drill Site No. 2 between 18 July and 27 August
1981 could be due to freshening as the saline pool followed the thaw front.

\section{Vascular plant response}

Within 12 days of the spill 17 taxa of vascular plants developed pronounced symptoms of physiological stress attributable to the treatment (Table 5, Fig. 7). The symptoms ranged from slight chlorosis of most of the leaves on a plant to total browning and desiccation of all the plant's foliage. Symptoms were considered extensive if they appeared in at least $75 \%$ of a population in one or more experimental plots and affected more than $75 \%$ of the plant's foliage, By 13 August 1980 symptoms had appeared in 34 taxa. Pronounced symptoms were observed in 22 of these taxa, while 8 taxa exhibited mild symptoms $(<50 \%$ of the plant or $<50 \%$ of the population affected). The symptoms in the remaining four taxa were possibly, but not clearly, attributable to the treatment, since similar symptoms were observed (but to a lesser extent) in plants in the control plots. These 34 taxa make up nearly all the shrub and forb veg. etation in the experimental plots. Only three species of forbs did not develop observable symptoms during the 1980 observation period: Saxifraga oppositifolia on the dry and mesic sites, and Pedicularis sudetica var. albolabiata and Saxifraga foliolosa on the wet sites.

Seven of the vascular plant taxa that developed pronounced symptoms were dwarf or prostrate shrubs. Six were willows (Salix spp.); the seventh was Dryas integrifolia ssp. integrifolia. Symptoms 
Table 5. Degree and character of physiological stress exhibited by plants affected by seawater experiment.

\begin{tabular}{|c|c|c|c|}
\hline Taxon & $\begin{array}{l}\text { Degree of } \\
\text { symptom } \\
\text { development }\end{array}$ & Description of symptoms (Atag. (3) & $\begin{array}{c}\text { Sites at } \\
\text { which symptoms } \\
\text { were observed }\end{array}$ \\
\hline $\begin{array}{l}\text { Androsace chamaejasme } \\
\text { sup. Lehmanniana }\end{array}$ & Extensive & Leaves orangish-brown, desiccated ( $50 \%$ of plants in plot). & Bd \\
\hline Cardamine hyperborea & Extensive & Petioles limp: leaflets brown, closed." & $\mathrm{Cm}$ \\
\hline Chrysanthemum integrifolium & Extensive & $\begin{array}{l}\text { Leaves chlorotic, limp, brown at tips in some cases: buds black, } \\
\text { unopened.* }\end{array}$ & $\mathrm{Cm}$ Bd Dd \\
\hline $\begin{array}{l}\text { Dryas imtegrifolla } \\
\text { ssp, integrifolia }\end{array}$ & Extensive & $\begin{array}{l}\text { Leaves rust-colored, desiccated, rolling back at margins." } \\
\text { (See Fig. Th.) }\end{array}$ & $\mathrm{Cw} \mathrm{Cm}$ Dd Bd Em \\
\hline Eutrema edwardsii & Extensive & Leaves brown, desiccated." & $\mathrm{Cm}_{\mathbf{m}}$ \\
\hline $\begin{array}{l}\text { Papaver lapponicum } \\
\text { ssp, occidentale }\end{array}$ & Extensive & Leaves brownish-black, limp. Pedicel limp, nearly decumbent." & $\mathrm{Cm}$ Bd \\
\hline Papaver macounii & Extensive & Leaves reddish-black, limp.* & $\mathrm{Cm} \mathrm{Dd}$ \\
\hline Pedicularis sp. & Extensive & Leaves black, limp." & Dd Em \\
\hline Perasites frigidus & Extensive & Leaves brown.* (See Fig. 7b.) & Em Am \\
\hline Polygonum viviparum & Extensive & A pical half of leaf brown, desiccated." & Em Dd Bd Cw \\
\hline $\begin{array}{l}\text { Salix arctica } \\
\text { ssp. arctica }\end{array}$ & Extensive & $\begin{array}{l}\text { Apical end of leaf brown, desiccated. Leaves tend to abseise when } \\
\text { touched." (See Fig. } 7 \mathrm{~g} \text {.) }\end{array}$ & $\mathrm{CW}_{\mathrm{w}}$ \\
\hline $\begin{array}{l}\text { Salix lanata } \\
\text { ssp. richardsonit }\end{array}$ & Extensive & $\begin{array}{l}\text { Leaves chlorotic, desiccated; apices brown. Leaves tend to abscise } \\
\text { touched." }\end{array}$ & $\mathrm{Cw}$ \\
\hline Salix ovalifolis & Extensive & Leaves chlorotic, desiceated: apices brown and curling." & Bd Am \\
\hline $\begin{array}{l}\text { Satix putchra = } \\
\text { Satix planifolia } \\
\text { sap. putchra }\end{array}$ & Extensive & $\begin{array}{l}\text { Leaves chlorotic, linp: apices yellow-brown, desiccated." } \\
\text { (See Fig. 7e.) }\end{array}$ & Em Am Ew \\
\hline $\begin{array}{l}\text { Satix reticulata } \\
\text { ssp. renculota }\end{array}$ & Extensive & $\begin{array}{l}\text { Leaves brown except small green area near base, desiccated, tend } \\
\text { to abscise when touched. } \\
\text { (See Fig. } 7 \mathrm{~d} \text {.) }\end{array}$ & $\mathrm{CW} \mathrm{Em} \mathrm{Cm}$ \\
\hline $\begin{array}{l}\text { Satix ronundifolia } \\
\text { ssp, romindifotia }\end{array}$ & Extensive & Leaves entirely brown." (See Fig. Tr.) & Em Am Ew \\
\hline Saxifrage cernua & Extensive & Leaves yellow, desiccated." & $\mathrm{Cm}$ \\
\hline $\begin{array}{l}\text { Senecio atropurpureus } \\
\text { ssp. frigidus }\end{array}$ & Extensive & Leaves entirely brown, desiccated. ${ }^{*}$ & $\mathbf{C m}$ \\
\hline Tanaxacum phymatocarpum & Extensive & Leaves chlorotic, limp, curled: apices brown." & $\mathrm{Cm}$ \\
\hline Draba ef. alpina & Extensive & Leaves yellow-brown, curled, desiccated. $\uparrow$ & $\mathrm{C} m \mathrm{Dd} \mathrm{Ew}$ Bd \\
\hline $\begin{array}{l}\text { Oxyiropis deflexa } \\
\text { var. foltolose }\end{array}$ & Extensive & Leaves very limp, darkened. $\dagger$ & Dd \\
\hline Potentilla pulchella & Extensive & Leaves dark yellow-qray, limp. $t$ & Bd \\
\hline Artemisia boreatis & Mild & Leaves yellow-gray to brown. (Aug. 18) & Bd \\
\hline Braya purpturascens & Mild & Leaves limp: tips chlorotic, desiccated ( $50 \%$ of plants in plot). & Bd \\
\hline $\begin{array}{l}\text { Melandrium apetalum } \\
\text { ssp. arcticum }\end{array}$ & Mild & Leaves brownish, limp, but plant still flowering. & Ew \\
\hline Minuartia arctica & Mild & Some leaves chlorotic to yellow-brown. & Cm Bd Dd \\
\hline $\begin{array}{l}\text { Oxytropis nigrescens } \\
\text { ssp, bryophita }\end{array}$ & Mild & Leaves brown, desiccated ( $50 \%$ of plants in plot). & Bd \\
\hline Saxifraga hirculus & Mild & Leaves brown in two plots." & Ew \\
\hline $\begin{array}{l}\text { Sedum rosed } \\
\text { ssp. integrifolitum }\end{array}$ & Mild & Leaves timp, blackened, abscise when touched. ( $50 \%$ ) & Bd \\
\hline Stellaria laeta & Mild & Leaves yellow-brown. Plant still flowering. & Am \\
\hline $\begin{array}{l}\text { Cassiope temagona } \\
\text { ssp. temagona }\end{array}$ & Questionable & Leaves black, red or gray. Little green growth remaining." & $E m$ \\
\hline Draba cf. lactea & Questionable & Leaves yellow-brown, curled.". & Ew \\
\hline Lloydia serotina & Questionable & Leaves chlorotic, limp, many decumbent. $*$ & Bd \\
\hline $\begin{array}{l}\text { Parrya nudicautis } \\
\text { ssp. nudicaulis }\end{array}$ & Questionable & Leaves yellow-brown, desiccated. $\cdots$ & Dd \\
\hline
\end{tabular}

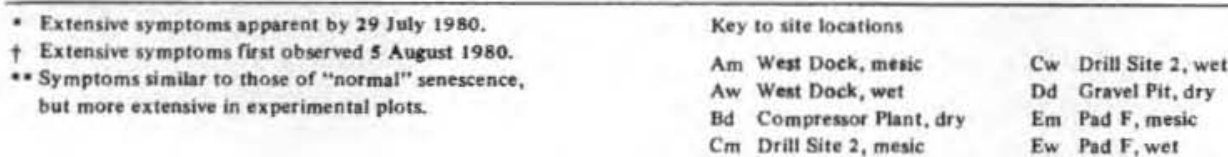




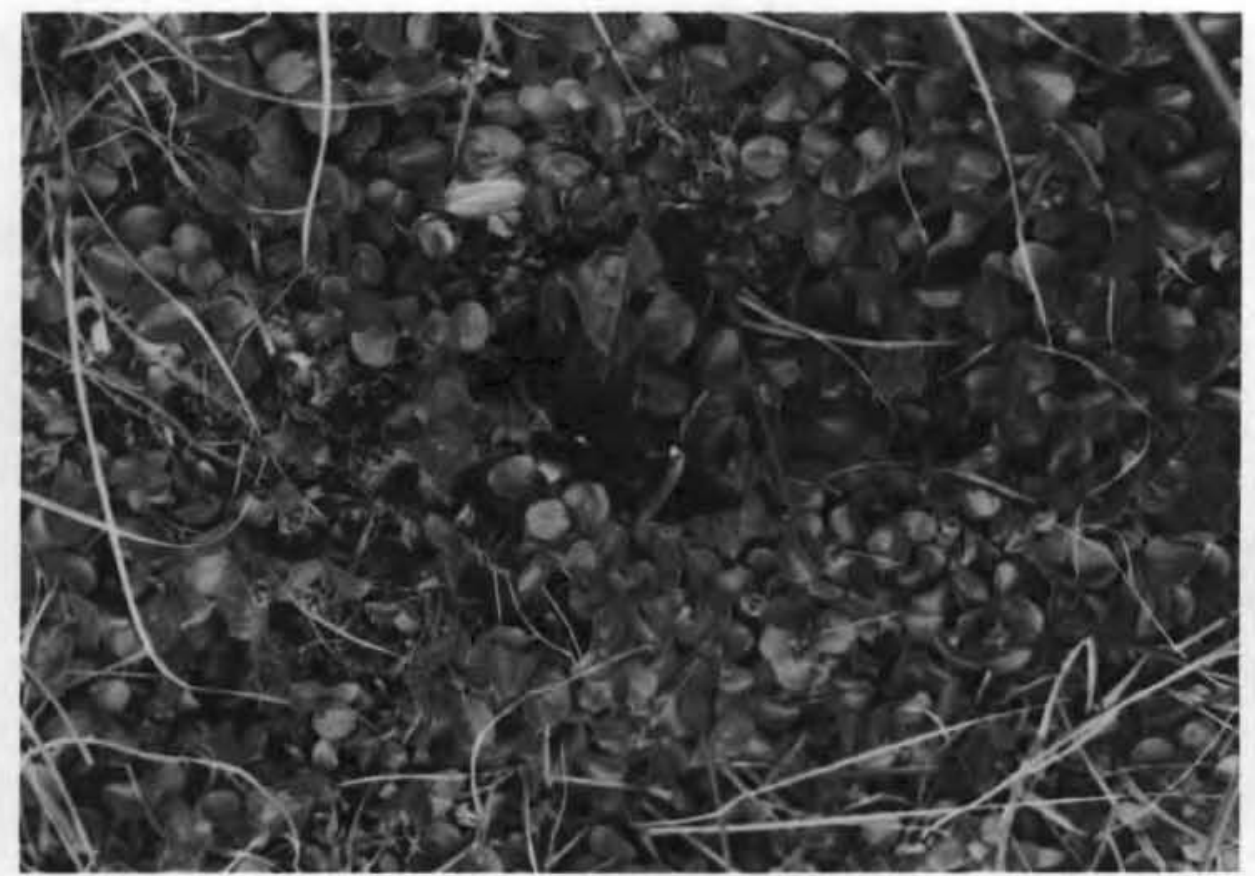

a. Petasites frigidus surrounded by Salix rotundifolia ssp. rotundifolia at the West Dock mesic control site. The purple color of $\mathrm{P}$. frigidus is normal; the red $\mathrm{S}$. rotundifolia is beginning to senesce. (I Aug 1980.)

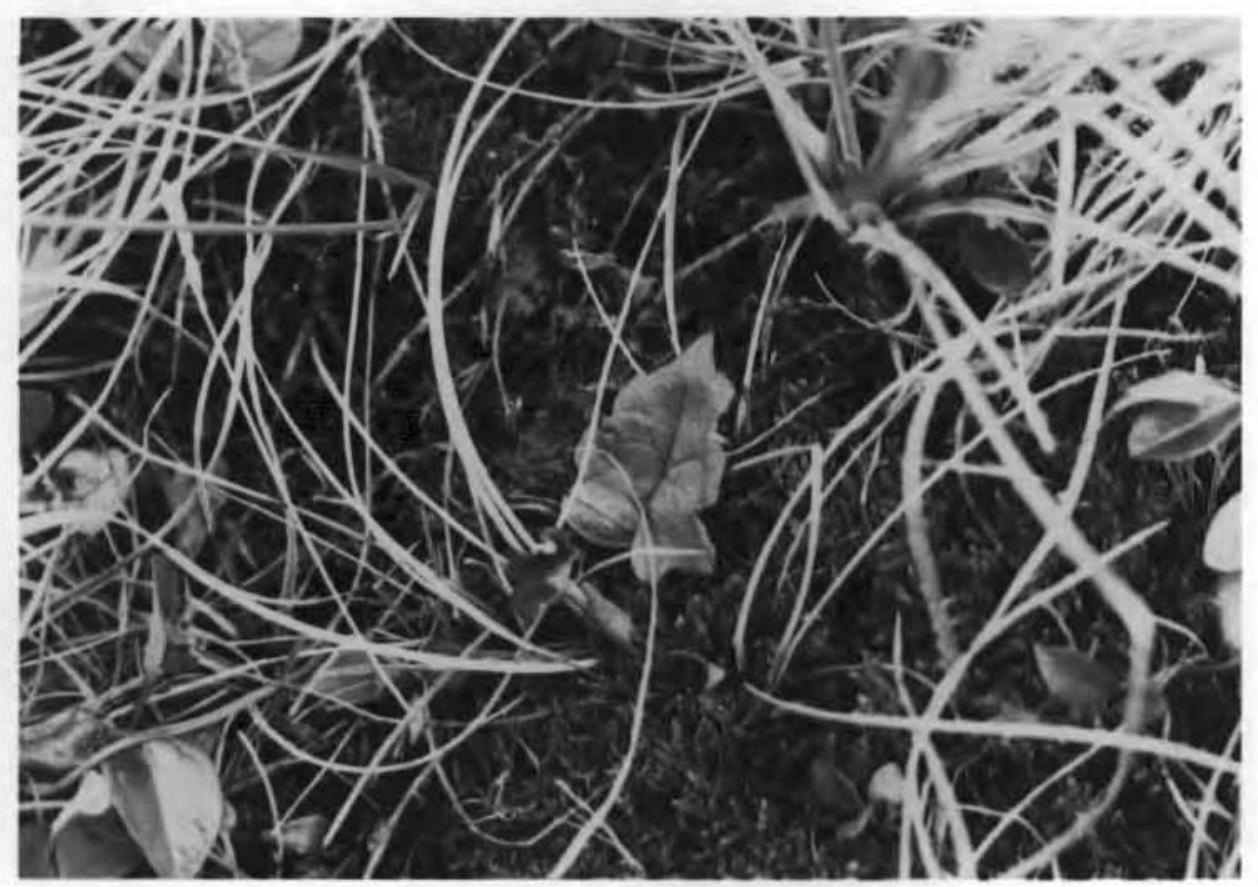

$b$. Petasites frigidus after seawater was applied at the West Dock mesic site. The leaf is totally brown, unlike the leaf in Fig. 7a. (I Aug 1980.)

Figure 7. Responses of vascular plants to a seawater spill. 


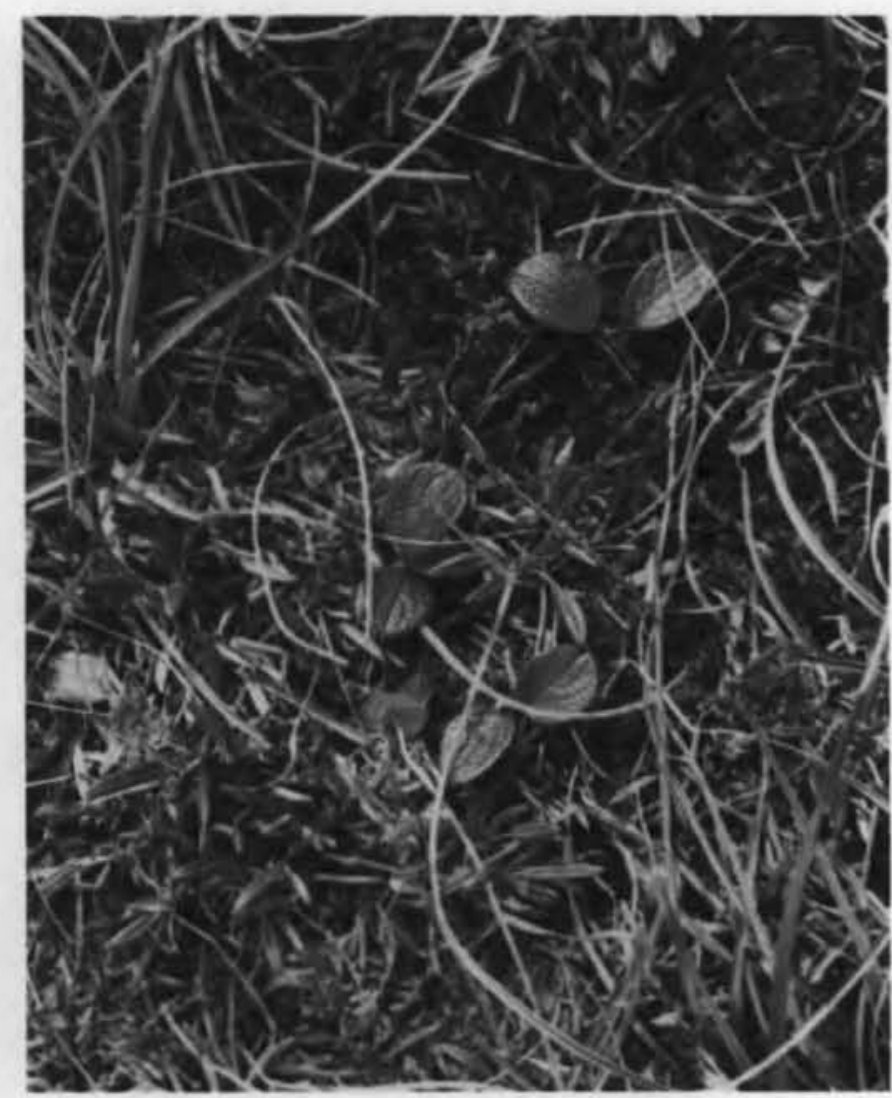

c. Untreated Salix reticulata $s s p$. reticulata and Dryas integrifolia ssp. integrifolia outside the spill area at Drill Site No. 2 mesic site. The leaves of both taxa are red due to normal senescence. (I Aug 1980.)

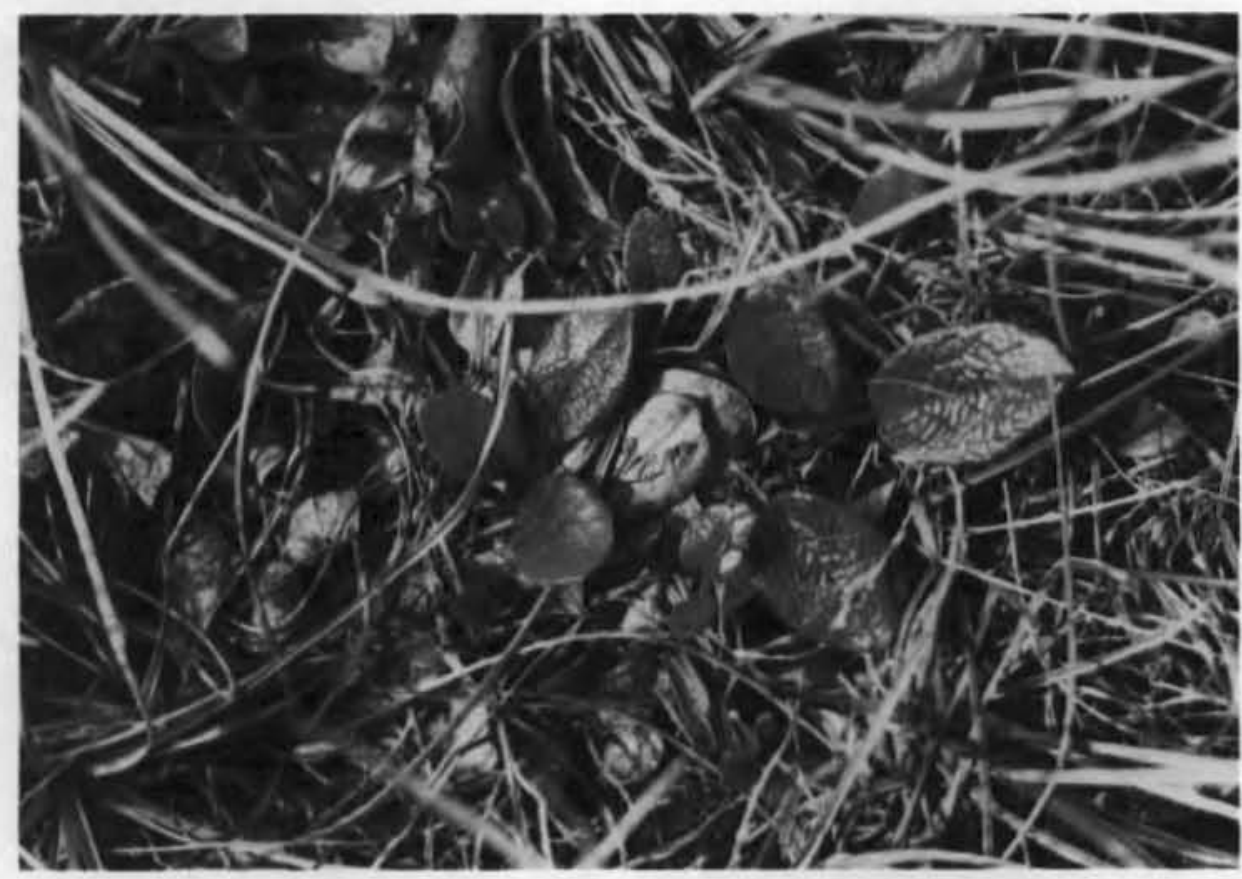

d. Seawater-treated Salix reticulata ssp. reticulata in the West Dock mesic spill area. Note the crescent-shaped brown area at the apical end of the leaf. This symptom was typical of $\mathrm{S}$. reticulata throughout the spill areas and was easily distinguished frem natural senescence (Fig. 7c). By the end of the observation period the brown area had increased to include the entire blade of most leaves. (1 Aug 1980.).

Figure 7 (cont'd). Responses of vascular plants to a seawater spill. 


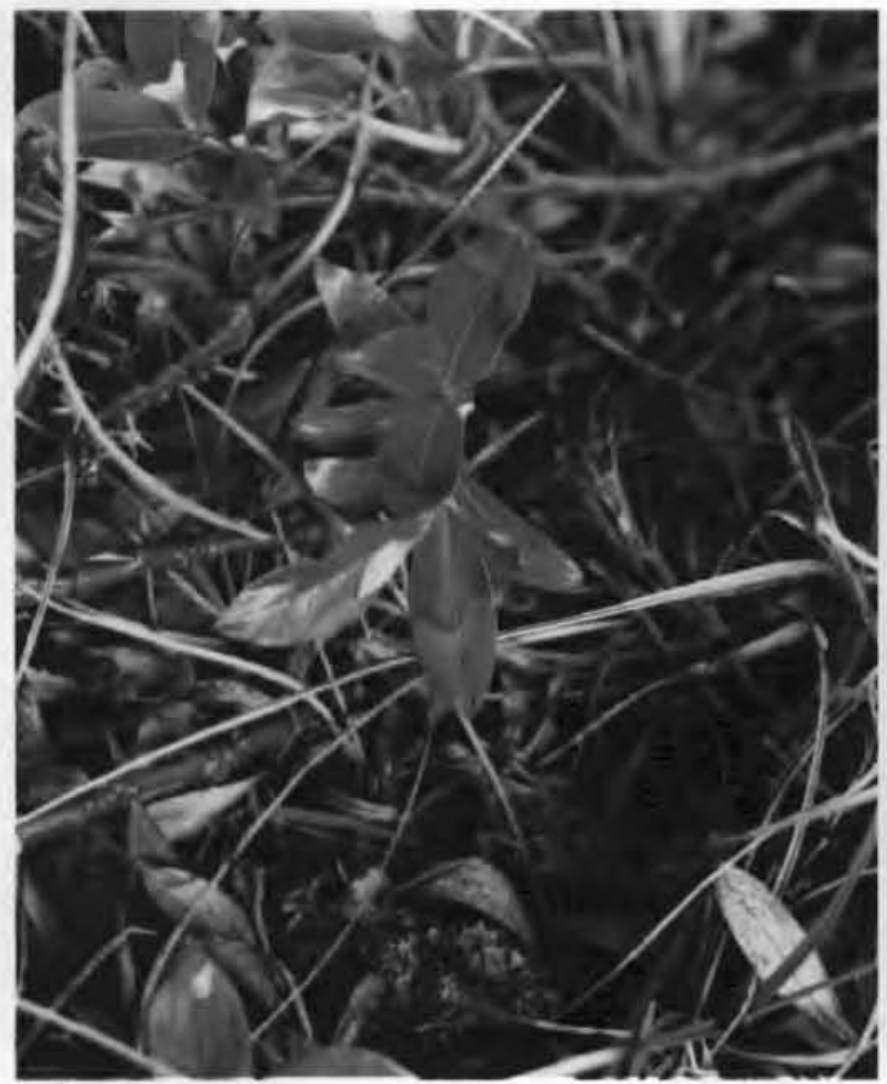

e. Salix pulchra at the West Dock mesic site following the seawater treatment. The typical symptom was chlorosis of the leaves followed by browning and desiccation of the apices of the leaves. (1 Aug 1980.)

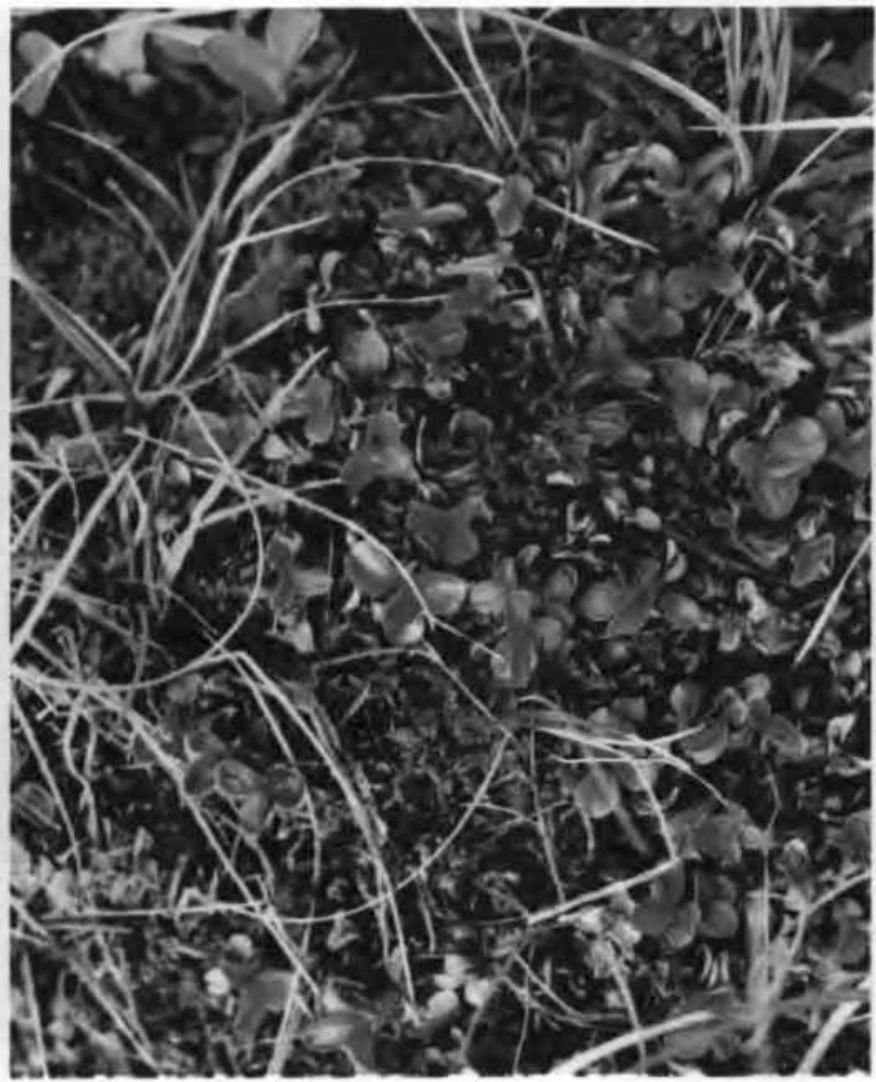

$f$. Salix rotundifolia $s s p$. rotundifolia at the West Dock mesic site after the seawater treatment. The leaves at the bottom of the picture have turned completely brown, presumably in response to the seawater treatment. (Compare with Fig. 7a.)The few green leaves at the top of the picture are on a small hummock. (1 Aug 1980.)

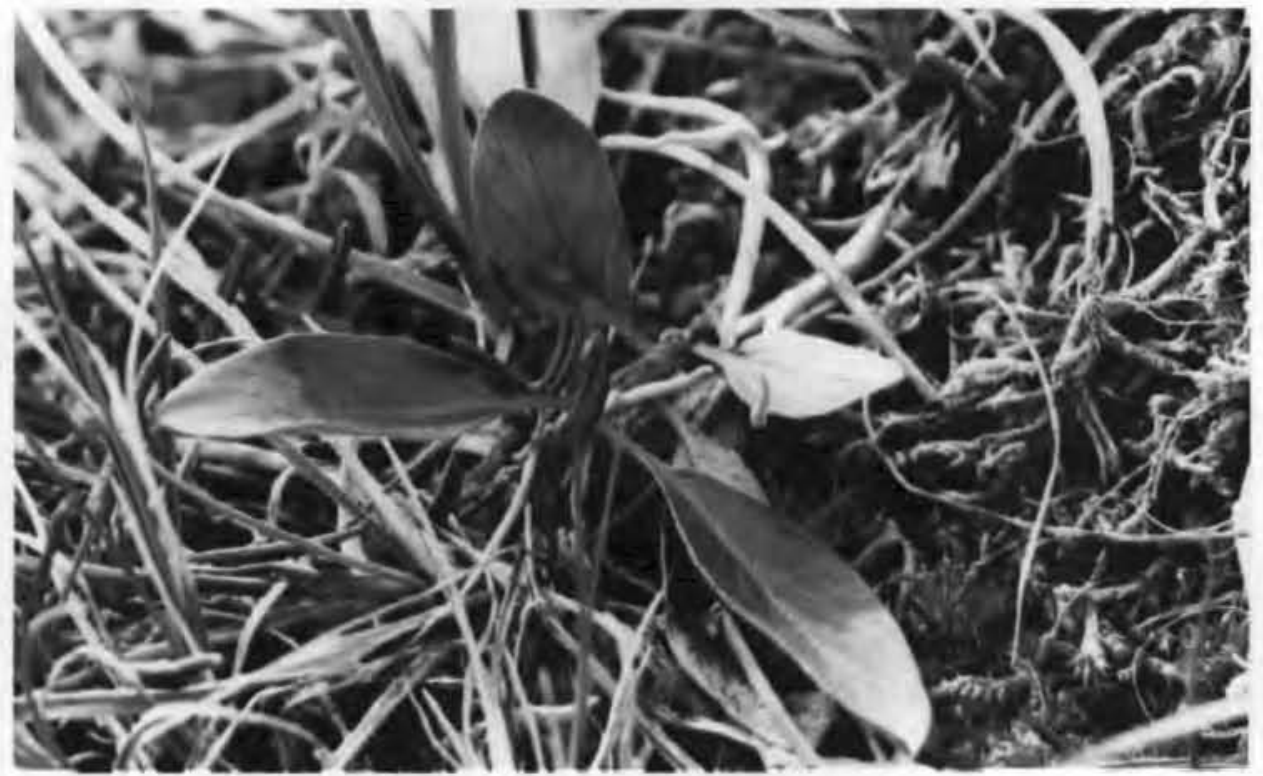

g. Typical symptoms observed in Salix arctica following the seawater treatment at the Drill Site No. 2 mesic site. The apical half of the leaf blade is brown. (1 Aug 1980.)

Figure 7 (cont'd). 


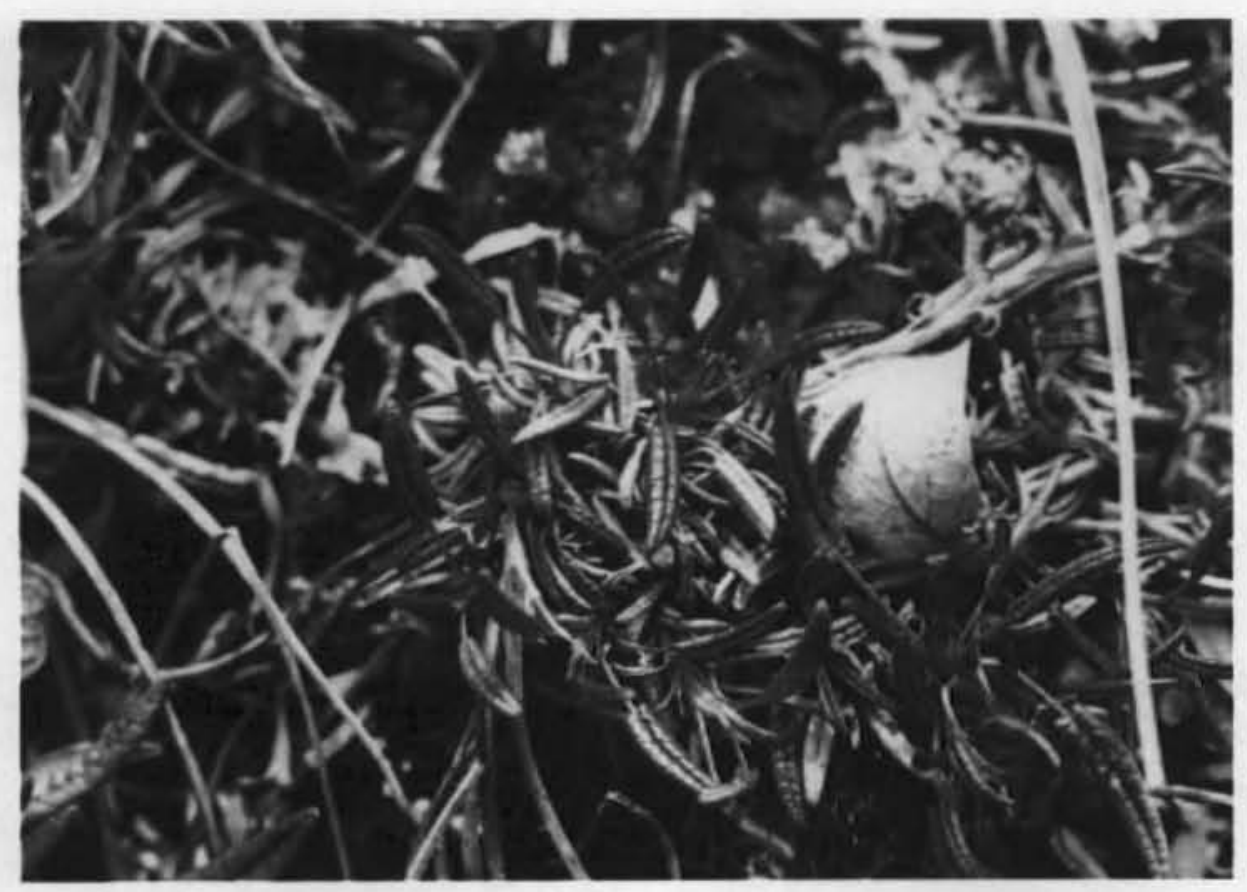

h. Dryas integrifolia ssp. integrifolia at Drill Site No. 2 after the seawater treatment. The rust-brown color of the treated plants is readily distinguishable from the red of normal senescence (Figs. $7 i$ and $j$ ). The symptom progressed from the apical end of the leaf towards the base; the bases of some of the leaf blades are still green. (I Aug 1980.)

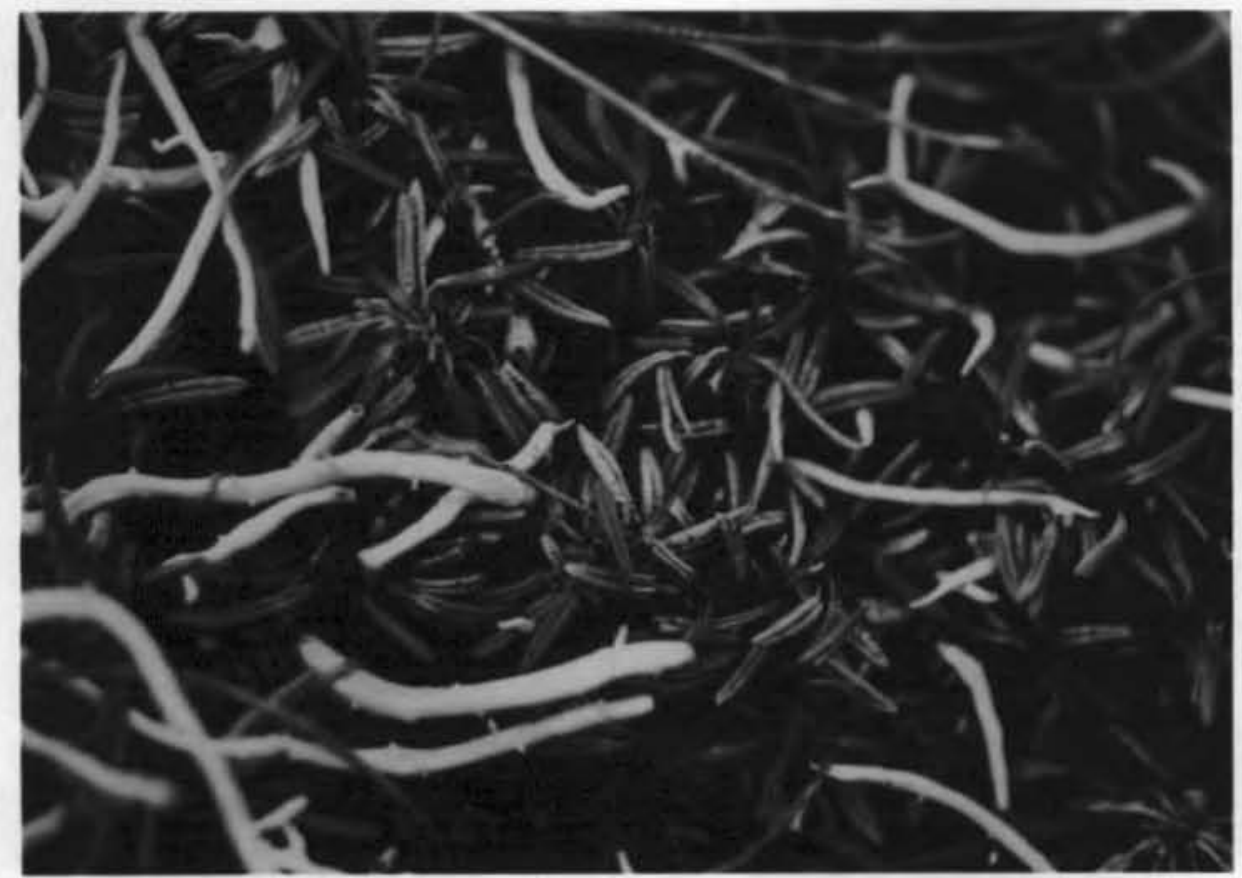

i. Leaves of Dryas integrifolia in the control plot at the Drill Site No. 2 mesic site in 1981. The white lichen is Thamnolia subuliformis.

Figure 7 (cont'd). Responses of vascular plants to a seawater spill. 


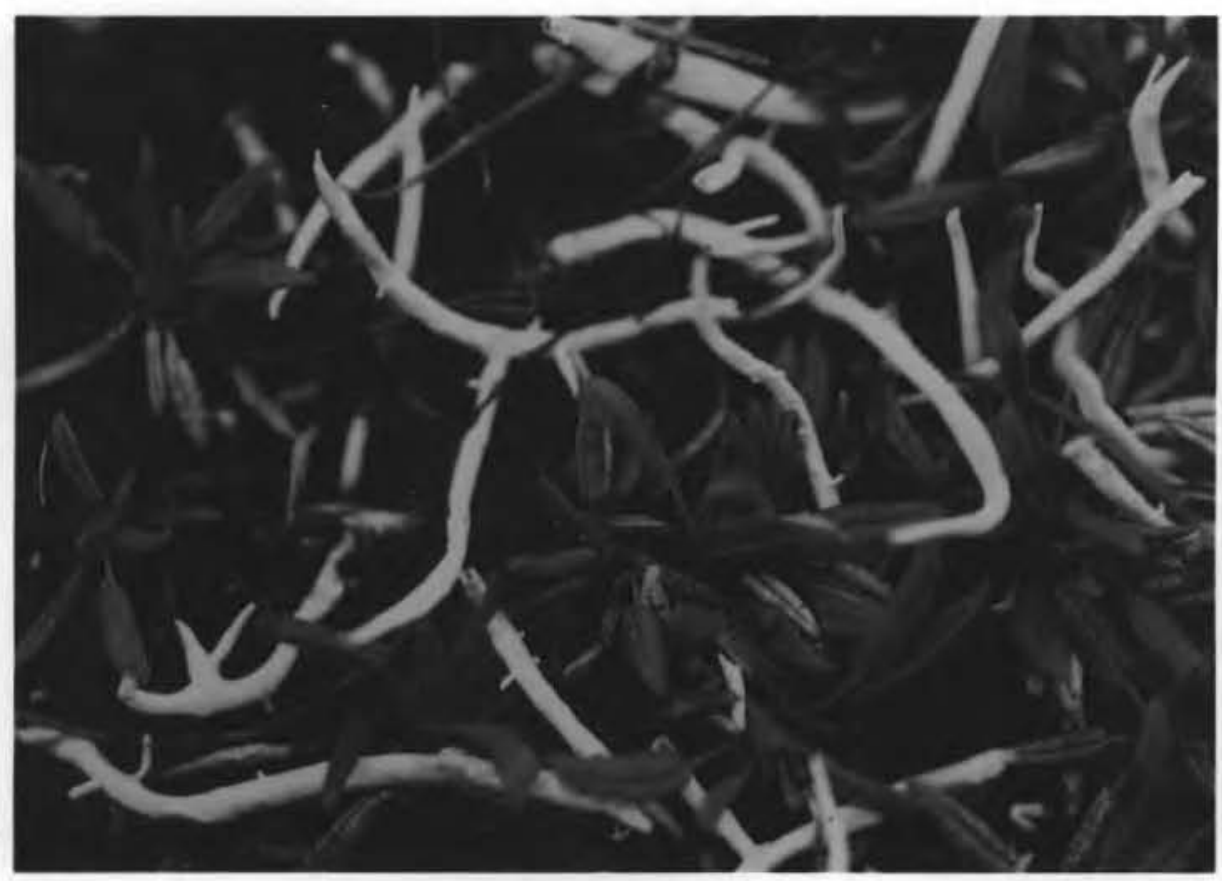

j. Leaves of Dryas integrifolia in an experimental plot at the Drill Site No. 2 mesic site in 1981. These plants produced no new foliage in 1981.

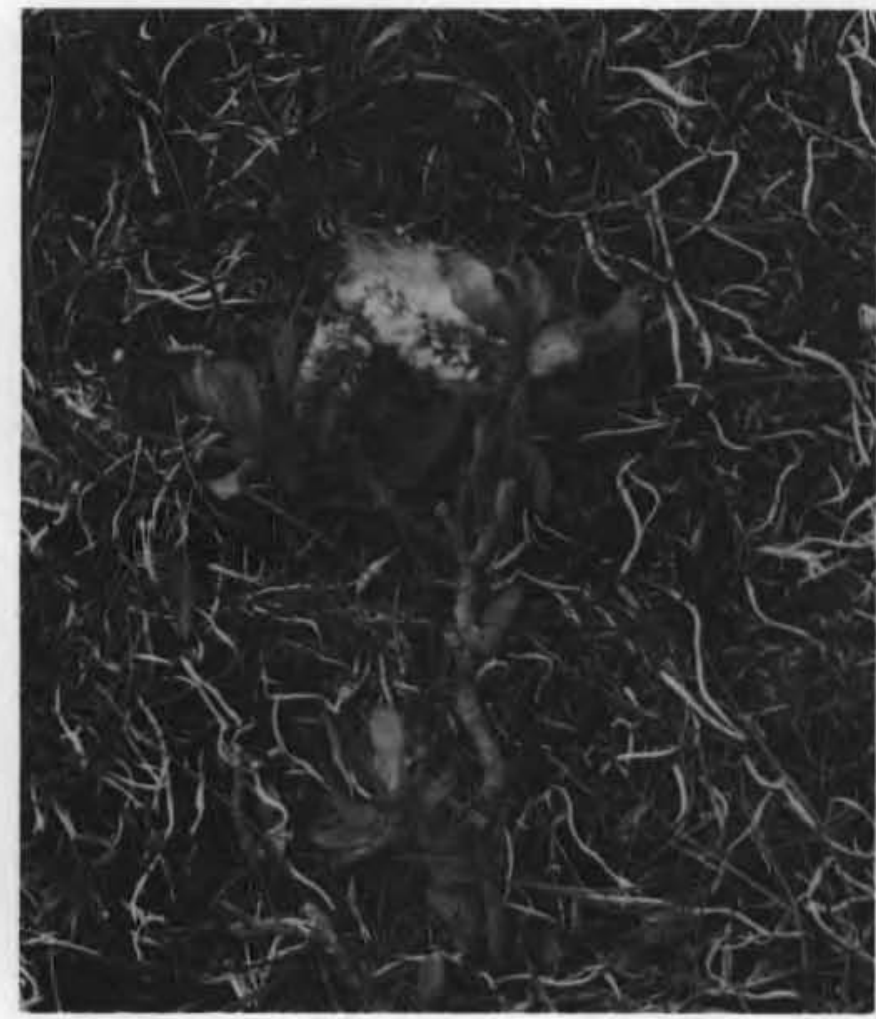

k. Salix lanata in the mesic experimental site at Drill Site No. 2 two weeks after the seawater treatment.

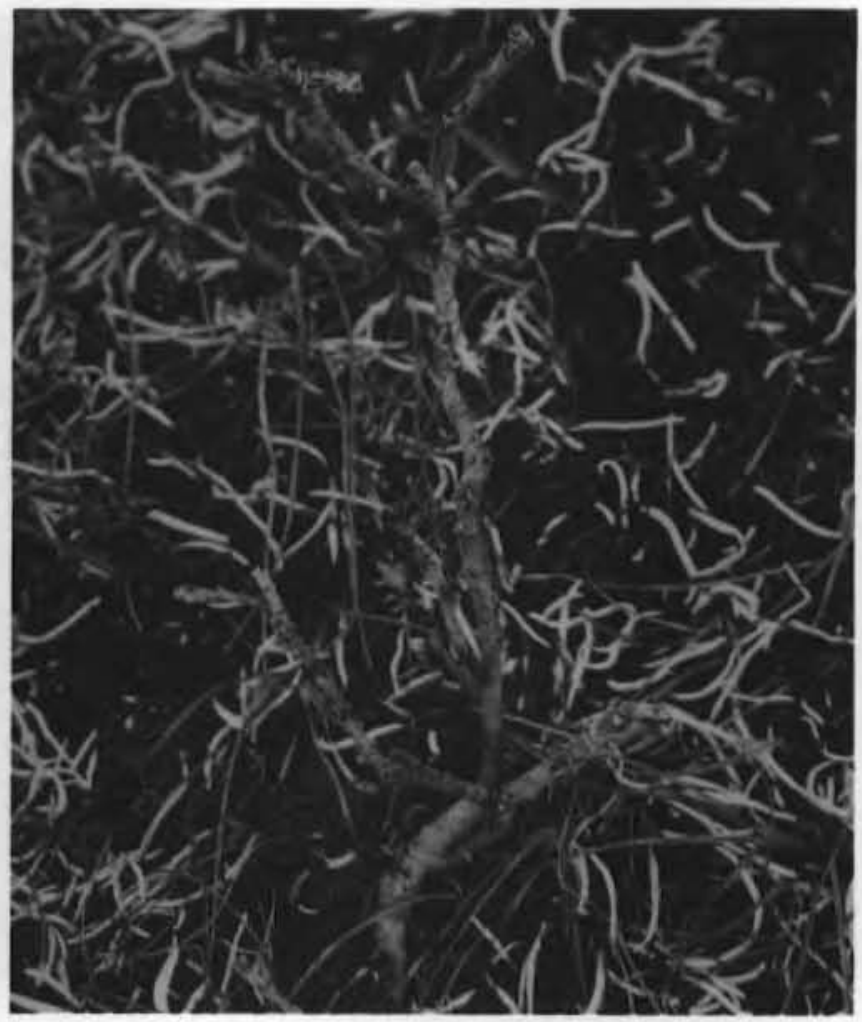

1. Salix lanata in the mesic experimental site at Drill Site No. 2 one year after the seawater treatment. No leaves were produced in 1981. (The same plant is pictured in Figure 7k.)

Figure 7 (cont'd). 
Table 6. Changes in percent cover for principal vascular taxa and total live vascular plant cover by site for 1980 and 1981 . See also Tables 7,8 and 9. Values for control plots are given in parentheses.

\begin{tabular}{|c|c|c|c|c|c|c|c|c|}
\hline \multirow[b]{2}{*}{ Site } & \multirow[b]{2}{*}{$\begin{array}{l}\text { Motrnure } \\
\text { caterory }\end{array}$} & \multirow[b]{2}{*}{ Texon } & \multirow[b]{2}{*}{$\begin{array}{l}\text { Growth } \\
\text { form }\end{array}$} & \multirow{2}{*}{$\begin{array}{l}\text { Area } \\
\text { covered } \\
\frac{(\mathbb{*})}{\text { Prespili }} \\
(t 950)\end{array}$} & \multicolumn{2}{|c|}{$\begin{array}{l}\text { Arra covered by } \\
\text { plant purta that } \\
\text { uere uneffected (z) }\end{array}$} & \multicolumn{2}{|c|}{$\begin{array}{l}\text { Total the nuscular } \\
\text { cowr on ate (f) }\end{array}$} \\
\hline & & & & & $\begin{array}{l}\text { Portspill } \\
\text { (1980) }\end{array}$ & $\begin{array}{l}\text { Fostspill } \\
(1981)\end{array}$ & $\begin{array}{l}\text { Premiti } \\
\text { (I9so) }\end{array}$ & $\begin{array}{l}\text { Pantspill } \\
\text { (t } 95 I)\end{array}$ \\
\hline \multirow[t]{7}{*}{$\begin{array}{l}\text { West Dock } \\
\text { Am }\end{array}$} & \multirow[t]{7}{*}{ Mesic } & $\begin{array}{l}\text { Sallex romandifolia } \\
\text { ssp. rotundifolia }\end{array}$ & Shrub & 18 & $<1$ & 3 & \multirow[t]{7}{*}{$41(27)$} & \multirow[t]{7}{*}{$19(32)$} \\
\hline & & Salix pulchre & Shrub & $<1$ & 0 & o & & \\
\hline & & $\begin{array}{l}\text { Salix ovalifolia } \\
\text { ssp. ovalifolia }\end{array}$ & Shrub & 4 & 1 & 1 & & \\
\hline & & Salix arctica & Shrub & 3 & $<1$ & $<1$ & & \\
\hline & & Carex aquatilis & Graminoid & 11 & 2 & 11 & & \\
\hline & & Eriophorum vdginatum & Graminoid & 3 & $<1$ & 3 & & \\
\hline & & Hierochloe pauciflora & Graminoid & $<1$ & $<1$ & $<1$ & & \\
\hline West Dock & \multirow[t]{2}{*}{ Wet } & Carex subspathaced & Graminoid & 85 & 85 & 85 & \multirow[t]{2}{*}{$85(90)$} & \multirow[t]{2}{*}{$85(90)$} \\
\hline Aw & & Dupontia fisheri & Graminoid & $<<1$ & $<<1$ & $\ll<1$ & & \\
\hline $\begin{array}{l}\text { Compressor } \\
\text { Plant }\end{array}$ & Dry & $\begin{array}{l}\text { Dryas integrifolia } \\
\text { ssp. integrifolia }\end{array}$ & Shrub & 21 & 0 & 0 & $27(24)$ & $3(29)$ \\
\hline \multirow[t]{5}{*}{ Bd } & & $\begin{array}{l}\text { Saltx ovelifolia } \\
\text { sap. ovatifolia }\end{array}$ & Shrub & 3 & 0 & 1 & & \\
\hline & & Carex rupesaris & Graminoid & $<1$ & $<1$ & $<$ & & \\
\hline & & $\begin{array}{l}\text { Carex scirpoides } \\
\text { Puccinellia andersonil }\end{array}$ & $\begin{array}{l}\text { Graminoid } \\
\text { Graminoid }\end{array}$ & $<1$ & $<1$ & $<1$ & & \\
\hline & & $\begin{array}{l}\text { Puccinellia andersonil } \\
\text { Saxifnaga opposinfotia }\end{array}$ & $\begin{array}{l}\text { Graminoid } \\
\text { Forb }\end{array}$ & $<1$ & $\begin{array}{l}<1 \\
<1\end{array}$ & $\begin{array}{l}<1 \\
<<1\end{array}$ & & \\
\hline & & $\begin{array}{l}\text { ssp. oppositifolia } \\
\text { Lloydia serotina }\end{array}$ & & $\ll<1$ & $<<1$ & $<<1$ & & \\
\hline Drill Site & \multirow[t]{6}{*}{ Mesic } & & & $<1$ & 0 & $<1$ & & \\
\hline No. 2 & & sp. integrifolia & Shrub & 18 & 0 & 0 & \multirow[t]{6}{*}{35 (38) } & \multirow[t]{6}{*}{$6(38)$} \\
\hline \multirow{4}{*}{$\mathrm{Cm}$} & & $\begin{array}{l}\text { Satiox reniculu ta } \\
\text { ssp. reticulata }\end{array}$ & Shrub & $<1$ & 0 & o & & \\
\hline & & Carex membranucea & Graminoid & 4 & 1 & & & \\
\hline & & Eriophorum angusrifoltum & Graminoid & 8 & $\begin{array}{l}1 \\
2\end{array}$ & $\begin{array}{l}1 \\
5\end{array}$ & & \\
\hline & & $\begin{array}{l}\text { Saxifragu oppositifolia } \\
\text { ssp. oppositifolia }\end{array}$ & Forb & 2 & 2 & $\begin{array}{l}5 \\
0\end{array}$ & & \\
\hline Drill Site & Wet & & & & & & & \\
\hline No. 2 & wet & $\begin{array}{l}\text { Salix lanata } \\
\text { ssp. richardsonil }\end{array}$ & Shrub & $<1$ & $<1$ & $<1$ & $18(22)$ & $19(22)$ \\
\hline $\mathrm{Cw}$ & & Carex equatilis & Graminoid & 9 & 9 & 9 & & \\
\hline & & Carex bigelowii & Graminoid & $<1$ & $<1$ & 0 & & \\
\hline & & Dupon tia fitheri & Graminoid & 6 & 6 & 6 & & \\
\hline & & Eriophorum angustifotium & Graminoid & 3 & 3 & 3 & & \\
\hline Gravel Pit & Dry & & & & & & & \\
\hline Dd & & $\begin{array}{l}\text { Dryas integrifolia } \\
\text { ssp. integrifolia }\end{array}$ & Shrub & 28 & 0 & 1 & $35(36)$ & $4(36)$ \\
\hline & & Carex rupestris & Graminoid & 1 & 1 & 2 & & \\
\hline & & $\begin{array}{l}\text { Saxifraga oppositifolta } \\
\text { sp. oppositifolia }\end{array}$ & Forb & 3 & 2 & $<1$ & & \\
\hline & & $\begin{array}{l}\text { Parrya nudicaulis } \\
\text { ssp. nudicaulis }\end{array}$ & Forb & $<1$ & 0 & 0 & & \\
\hline $\begin{array}{l}\text { Pad } F \\
E_{m}\end{array}$ & Mesic & $\begin{array}{c}\text { Dryas integrifolia } \\
\text { ssp, integrifolia }\end{array}$ & Shrub & 9 & o & 0 & $37(34)$ & $10(30)$ \\
\hline & & $\begin{array}{l}\text { Salix ronundifolia } \\
\text { sw. ronundifolia }\end{array}$ & Shrub & $\ll<1$ & 0 & 0 & & \\
\hline & & Saltx pulchra & Shrub & 10 & 0 & 1 & & \\
\hline & & $\begin{array}{l}\text { Salix reticulata } \\
\text { upp, reticulata }\end{array}$ & Shrub & 6 & 0 & 0 & & \\
\hline & & Carex bigelowii & Graminoid & ? & 6 & 6 & & \\
\hline & & Duponria flaheri & Graminoid & $<1$ & $<1$ & $<1$ & & \\
\hline & & Erlophonum angustifoltum & Graminoid & 2 & 2 & 2 & & \\
\hline & & Erlophonum vaginatum & Graminoid & 1 & $<1$ & $<1$ & & \\
\hline & & $\begin{array}{l}\text { Cansiope temagona } \\
\text { ssp. tetragona }\end{array}$ & Shrub & 3 & $<1$ & $<1$ & & \\
\hline Pad F & Wet & Satix pulchra & Shrub & $\ll 1$ & 0 & $\ll<1$ & $16(11)$ & $13(11)$ \\
\hline Ew & & Carex aquatilis & Graminoid & 9 & 9 & 8 & & \\
\hline & & Carex misendra & Graminoid & $<1$ & $<1$ & $<1$ & & \\
\hline & & Eriophonam angustifoltum & Graminoid & 1 & 1 & 1 & & \\
\hline & & Eriophorum of. nusseolum & Graminoid & 1 & 1 & 1 & & \\
\hline & & Juncus bighumis & Graminoid & $\ll<1$ & $<1$ & $<<1$ & & \\
\hline & & $\begin{array}{l}\text { Pedicularis sudeticat } \\
\text { var, albolabiaste }\end{array}$ & Forb & $\ll 1$ & $<1$ & $<1$ & & \\
\hline & & Drabe ef. lacted & Forb & $\ll<1$ & 0 & 0 & & \\
\hline
\end{tabular}


appeared in these plants within nine days of the spill and by 5 August 1980 affected nearly all of each plan's leaves. Because shrubs represented as much as $89 \%$ of the total live vascular plant cover in some areas, their decline was particularly conspicuous. The remaining 14 species that were strongly affected were forbs. These species constituted less than $5 \%$ of the vascular plant cover in the experimental plots.

None of the 14 species of graminoids in the study areas developed clear symptoms of stress. Graminoid species make up nearly all of the vascular plant vegetation in the wet sites and approximately a third in the mesic sites. The graminoiddominated wet sites were apparently little affected by the seawater (Table 6 ). The grasses and sedges in the mesic spill areas appeared slightly browner than those in the control plots; however, the difference was not great enough to be clearly attributable to the seawater treatment. There was no indication that the few graminoids in the dry sites were affected by the seawater treatment.

Plants in experimental plots that were totally submerged during the period of the spill exhibited nearly uniform, species-specific responses to the treatment, regardless of differences in microrelief within the plot and distance from the spill point. Where small hummock "islands" projected above the ponded seawater, as in some of the mesic sites, microrelief affected the rate or degree of symptom development in some taxa but not in others. In Salix rotundifolia ssp. rotundifolia, for example, more pronounced symptoms appeared in the plants in the lower microsites, while Salix reticulata ssp. reticulate and Petasites frigidus were sensitive regardless of differences in microrelief (Fig. 7a-d). The different responses of these taxa may be related to differences in root depth and/or root spread, and to the sensitivity of the leaves to seawater. In the mesic and wet sites the relationship between degree of symptom development and microtopographical location was strongest during the initial two weeks after the spill. By 5 August the symptoms were nearly uniform within each of the taxa in these areas. In the dry sites, on the other hand, many of the plants on the higher microsites in the incompletely submerged plots remained free of stress symptoms for the duration of the observation period. A notable exception is Dryas integrifolia ssp. integrifolia, the predominant cover in the dry areas, which eventually developed symptoms in most of the higher microsites (Tables 5 and 6). This response may be related to the considerable root spread of Dryas integrifolia. Low lateral mobility of salts in the dry-site soils may be responsible for the absence of symptoms in many of the other plants on the higher microsites.

The wet-site vegetation at the West Dock coas. tal area developed no observable symptoms following the seawater treatment. This result is not surprising in light of the narurally high conductiviry of the soil solution before the spill (Table 3) and the evidence of past seawater inundation in the area. In addition the vegetation in this site consists almost entirely of Carex subspathaceo, a species common in Alaskan coastal salt marshes (Hultén 1968), On 28 August 1980 the wet site was nearly covered by seawater that had naturally flooded the study area." The experimental and control plots contained seawater $5-10 \mathrm{~cm}$ deep. with a few hummocks protruding above the water.

Where microrelief features formed runoff channels, such as the troughs adjacent to ice-wedge polygons in the mesic sites, vegetation was damaged along the channel bottoms. Salix reticulata and Salix rotundifolia appear to be particularly sensitive indicators of seawater runoff routes.

The 1981 observations substantiated the 1980 trends. The live vascular plant cover in the mesic and dry sites was considerably reduced from prespill values (Table 6). Many of the taxa that had exhibited extreme symptoms in 1980 produced bitle or no foliage in 1981. These included the shrubs Dryas integrifolia and Salix ssp., which are important cover taxa in the dry and mesic areas (Fig. 7). The forb cover was noticeably reduced in these sites as well, with fewer species and fewer individuals in the treated plots (Tables 7 and 8). In addition there was a reduction in the live cover of Cassiope tetragona and Saxifraga oppositifolia, species that are of moderate importance in the mesic and dry areas but had not developed elear symptoms of stress in 1980. While the decrease in forb cover did not greatly affect the total live cover values, it represents a reduction in the diversity of vascular species within the treatment areas, particularly in the dry sites. Two forb species. Braya purpurascens and Chrysanthemum integrifolium, increased in abundance in at least one experimental plot in the dry sites (Table 8). Both of these species are common in salt-affected areas along the coastal bluffs. The new individuals were tiny rosettes that contributed little to the total cover. The abundance of these species decreased in some of the plots; the inconsistency may be related to unequal distribution of salts in the soil.

\footnotetext{
- Personal communication with S. Degler, Sohio-Alaska Pe troleum Company.
} 
Table 7. Numbers of vascular plant taxa in the experimental and control plots for 1980 and 1981 by vegetation categoy.

\begin{tabular}{|c|c|c|c|c|c|c|}
\hline \multirow[b]{3}{*}{ Site } & \multirow[b]{3}{*}{$\begin{array}{l}\text { Motsture } \\
\text { category }\end{array}$} & \multirow[b]{3}{*}{$\begin{array}{c}\text { Growth } \\
\text { form }\end{array}$} & \multicolumn{4}{|c|}{ Number of vascular plant taxa } \\
\hline & & & \multicolumn{2}{|c|}{ Experimental plots* } & \multicolumn{2}{|c|}{ Control plot } \\
\hline & & & $\begin{array}{r}\text { Prespill } \\
(1980)\end{array}$ & $\begin{array}{c}\text { Postspill } \\
\text { (1981) }\end{array}$ & $\begin{array}{r}\text { Prespill } \\
(1980) \\
\end{array}$ & $\begin{array}{l}\text { Postspill } \\
\text { (1981) }\end{array}$ \\
\hline West Dock & Mesic & Shrub & 4 & 3 & 4 & 4 \\
\hline \multirow[t]{3}{*}{ Am } & & Forb & 3 & 2 & 3 & 2 \\
\hline & & Graminoid & 3 & 3 & 2 & 2 \\
\hline & & Total & 10 & 8 & 9 & 8 \\
\hline \multirow{4}{*}{$\begin{array}{l}\text { West Dock } \\
\text { Aw }\end{array}$} & Wet & Shrub & $\mathbf{0}$ & 0 & $\mathbf{0}$ & 0 \\
\hline & & Forb & 0 & 0 & $\mathbf{0}$ & 0 \\
\hline & & Graminoid & 2 & 2 & 2 & 2 \\
\hline & & Total & 2 & 2 & 2 & 2 \\
\hline \multirow{4}{*}{$\begin{array}{l}\text { Compressor } \\
\text { Plant } \\
\text { Bd }\end{array}$} & Dry & Shrub & 2 & 1 & 2 & 2 \\
\hline & & Forb & 14 & 10 & 11 & 12 \\
\hline & & Graminoid & 3 & 3 & 3 & 3 \\
\hline & & Total & 19 & 14 & 16 & 17 \\
\hline \multirow{5}{*}{$\begin{array}{l}\text { Drill Site } \\
\text { No. } 2 \\
\text { Cm }\end{array}$} & Mesic & Shrub & 3 & 1 & 3 & 3 \\
\hline & & Forb & 9 & 1 & 5 & 7 \\
\hline & & Graminoid & 2 & 2 & 2 & 2 \\
\hline & & Equisetum & 1 & 0 & 1 & 0 \\
\hline & & Total & 15 & 4 & 11 & 12 \\
\hline \multirow{5}{*}{$\begin{array}{l}\text { Drill Site } \\
\text { No. } 2 \\
\text { Cw }\end{array}$} & Wet & Shrub & 4 & 4 & 4 & 3 \\
\hline & & Forb & 2 & 1 & 1 & 1 \\
\hline & & Graminoid & 4 & 4 & 3 & 3 \\
\hline & & Equisetum & 1 & 1 & 1 & 1 \\
\hline & & Total & 11 & 10 & 9 & 8 \\
\hline \multirow{4}{*}{$\begin{array}{l}\text { Gravel Pit } \\
\text { Dd }\end{array}$} & Dey & Shrub & 1 & 1 & 1 & 1 \\
\hline & & Forb & 10 & 3 & 8 & 8 \\
\hline & & Graminoid & 3 & 3 & 1 & 1 \\
\hline & & Total & 14 & 7 & 10 & 10 \\
\hline \multirow{4}{*}{$\begin{array}{c}\text { Dad F } \\
\text { Em }\end{array}$} & Mesic & Shrub & 4 & 3 & 4 & 4 \\
\hline & & Forb & 3 & 1 & 1 & 1 \\
\hline & & Graminoid & 4 & 4 & 2 & 2 \\
\hline & & Total & 11 & 8 & 7 & 7 \\
\hline \multirow{4}{*}{$\begin{array}{c}\text { Pad F } \\
\text { Ew }\end{array}$} & Wet & Shrub & 3 & 3 & 0 & 1 \\
\hline & & Forb & 8 & 6 & 7 & 7 \\
\hline & & Graminoid & 5 & 6 & 6 & 6 \\
\hline & & Total & 16 & 15 & 13 & 14 \\
\hline
\end{tabular}

-Total for three experimental plots.

The graminoid taxa did not appear to have been adversely affected by the seawater treatment except in the Drill Site No. 2 mesic site, where a slight reduction in live cover was observed. Flowering of the graminoids in the experimental plots was approximately equivalent to that in the control plots.

The dry and mesic sites were observed briefly on
5 and 11 August 1982. Although no cover estimates were made, partial recovery of the willows was apparent in the West Dock mesic site and the Compressor Plant dry site; live foliage had increased since 1981. The remaining sites appeared much as they had in 1981; there were no signs of further recovery. 
Table 8. Numbers of individuals of selected vascular plant taxa (forbs) in the experimental and control plots for 1980 and 1981.

\begin{tabular}{|c|c|c|c|c|c|c|}
\hline \multirow[b]{3}{*}{ Site } & \multirow[b]{3}{*}{$\begin{array}{l}\text { Moisture } \\
\text { category }\end{array}$} & \multirow[b]{3}{*}{ Taxon } & \multicolumn{4}{|c|}{ Number of individuals } \\
\hline & & & \multicolumn{2}{|c|}{ Experimental plots } & \multicolumn{2}{|c|}{ Control plots } \\
\hline & & & $\begin{array}{l}\text { Prespill } \\
\text { (1980) }\end{array}$ & $\begin{array}{l}\text { Postspill } \\
\text { (1981) }\end{array}$ & $\begin{array}{l}\text { Prespill } \\
(1980) \\
\end{array}$ & $\begin{array}{l}\text { Postspill } \\
\text { (1981) }\end{array}$ \\
\hline $\begin{array}{l}\text { West Dock } \\
\text { Am }\end{array}$ & Mesic & Petasites frigidus (3)* & 19 & 12 & 20 & 21 \\
\hline $\begin{array}{l}\text { West Dock } \\
\text { Aw }\end{array}$ & Wet & None & & & & \\
\hline \multirow{8}{*}{$\begin{array}{l}\text { Compressor } \\
\text { Plant } \\
\text { Bd }\end{array}$} & Dry & Artemisia borealis (1) & 1 & 1 & 1 & 1 \\
\hline & & Oxytropis nigrescens (1) & 1 & 0 & 2 & 2 \\
\hline & & Draba cf. alpina (3) & 8 & 0 & 2 & $-t$ \\
\hline & & Braya purpurascens (1) & 13 & 20 & - & - \\
\hline & & $\begin{array}{l}\text { Taraxacum } \\
\text { phymatocarpum (2) }\end{array}$ & 2 & 2 & 1 & 1 \\
\hline & & Potentilla pulchella (2) & 3 & 2 & 0 & 0 \\
\hline & & Papaver lapponicum (1) & 1 & 0 & 0 & 0 \\
\hline & & $\begin{array}{l}\text { Chrysanthemum } \\
\text { integrifolium (3) }\end{array}$ & 2 & 11 & 1 & 1 \\
\hline \multirow{4}{*}{$\begin{array}{l}\text { Drill Site } \\
\text { No. } 2 \\
\text { Cm }\end{array}$} & Mesic & Papaver macounii (3) & 25 & 0 & $\mathbf{0}$ & 0 \\
\hline & & Papaver lapponicum (1) & 1 & 0 & 2 & 5 \\
\hline & & $\begin{array}{l}\text { Chrysanthemum } \\
\text { integrifolium (3) }\end{array}$ & 7 & $\mathbf{0}$ & $\mathbf{0}$ & o \\
\hline & & Draba cf. alpina (2) & 9 & 0 & 2 & 2 \\
\hline $\begin{array}{l}\text { Drill Site } \\
\text { No. } 2 \\
\text { Cw }\end{array}$ & Wet & $\begin{array}{l}\text { Pedicularis sudetica } \\
\text { ssp. albolabiata (1) }\end{array}$ & 10 & 11 & 0 & 1 \\
\hline \multirow{7}{*}{$\begin{array}{l}\text { Gravel Pit } \\
\text { Dd }\end{array}$} & Dry & Parrya nudicaulis (2) & 3 & 0 & $\mathbf{0}$ & 0 \\
\hline & & $\begin{array}{l}\text { Chrysanthemum } \\
\text { integrifolium (3) }\end{array}$ & 9 & 2 & 9 & 9 \\
\hline & & Oxytropis deflexa (1) & 8 & 0 & 1 & 1 \\
\hline & & Braya purpurascens (3) & 2 & 5 & 3 & 1 \\
\hline & & Pedicularis sp. (2) & 1 & 0 & 1 & 1 \\
\hline & & Polygonum viviparum (1) & 1 & 0 & 1 & 1 \\
\hline & & Papaver macounii (1) & 2 & 0 & 0 & $\mathbf{0}$ \\
\hline $\begin{array}{l}\text { Pad F } \\
\text { Em }\end{array}$ & Mesic & Pedicularis sp. (2) & 2 & 0 & 4 & 3 \\
\hline $\begin{array}{l}\text { Pad F } \\
\text { Ew }\end{array}$ & Wet & Saxifraga foliolosa (3) & 65 & 43 & 31 & 38 \\
\hline
\end{tabular}

- The number of experimental plots in which individuals were counted is given in parentheses. †Not counted.

\section{Cryptogam response}

During the 1980 observation period there was a general browning of the predominant bryophytes in some of the experimental plots, particularly in the Drill Site No. 2 mesic and wet sites. However, this also occurred in some of the surrounding untreated area, and to a lesser degree in the control plots, so it was not clearly attributable to the seawater treatment. By 13 August 1980 dormancy of the bryophytes throughout the study area had progressed to the point where there was no apparent difference between those in the spill area and those outside it.

The 1981 observations helped to clarify the bryophyte response. Nearly all of the bryophyte cover in the mesic and dry experimental plots remained brown throughout the summer of 1981 . However, the bryophytes in the dry-site control plots pro- 
Table 9. Changes in percent live vegetation cover by growth form in the experimental and control plots for 1980 and 1981 .

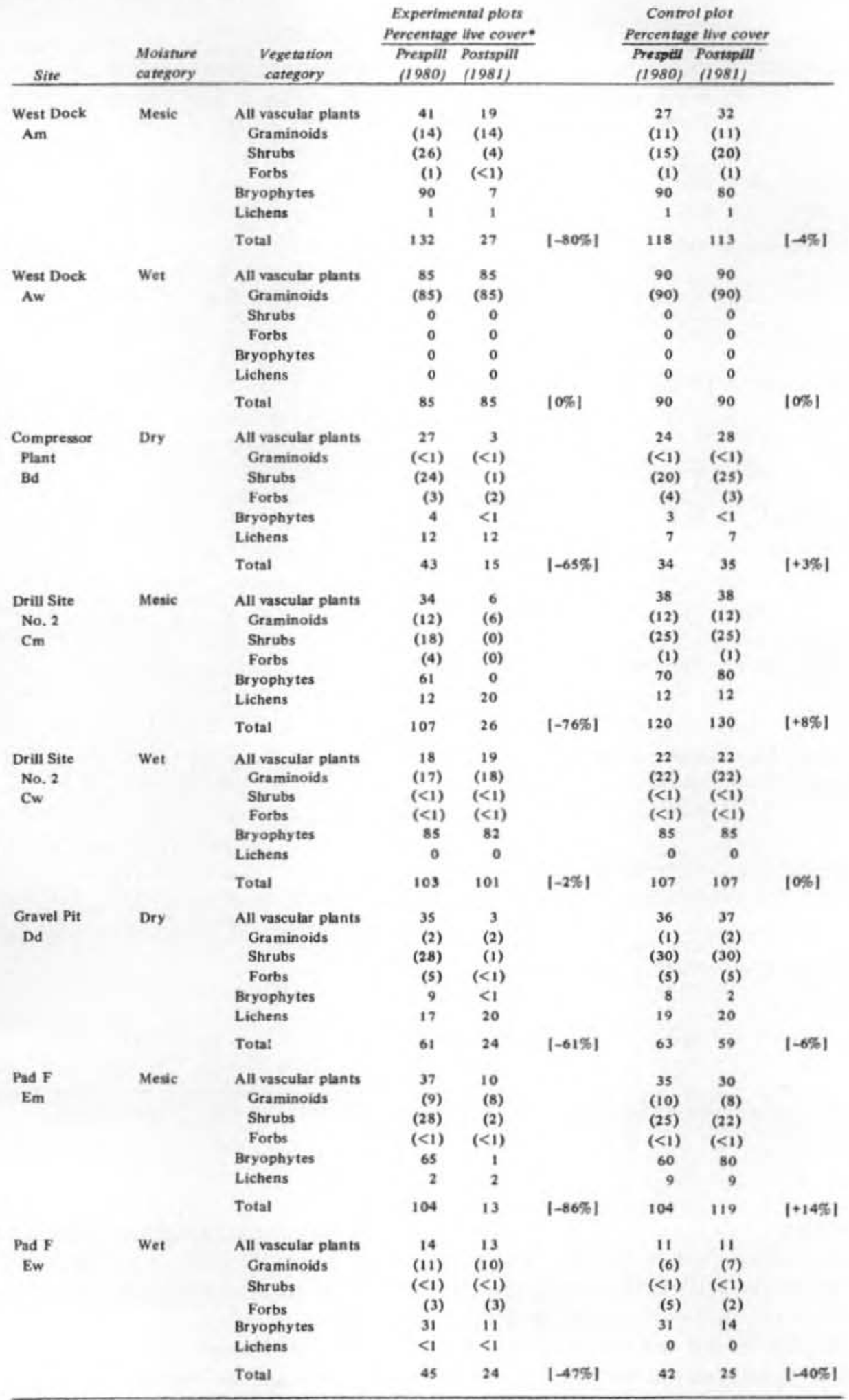

I 1 Percentage change in total live cover $=\frac{\text { (postspill value) }- \text { (prespill value) }}{\text { prespill value }} \times 100 \%$

- Mean value for three experimental plots. 
duced only slightly more green growth than those in the experimental plots (Table 9). The browner condition of the mosses in the dry sites in 1981 may be due to differences in precipitation between 1980 and 1981. The August-September precipitation in 1981 was only $40 \%$ of that in 1980 for the same period. - Within the mesic sites, on the other hand, the live (green) bryophyte cover was about $80 \%$ in the control plots, and the average values for the experimental plots ranged from 0 to $7 \%$. The small amount of green bryophyte growth was somewhat obscured by the surrounding brown material, making it difficult to determine the relative abundance of the different species. All of the species produced some green growth in some plots. No conclusions could be drawn regarding the relative resilience of different bryophyte taxa. The bryophytes in the mesic areas were undoubtedly affected adversely by the seawater treatment. However, since these plants typically become dormant during adverse conditions and resume growth when conditions improve, the long-term effects on these plants cannot be predicted. The bryophytes in the wet sites appeared much the same in the experimental and control plots, except for a single plot at Drill Site No. 2 in which the bryophytes appeared to be somewhat discolored.

No lichen taxa developed observable symptoms in 1980 following seawater treatment. In 1981 the majority of the lichens still appeared to have been unaffected. However, two foliose species, Peltigera aphthosa and Solorina saccata, became quite discolored and showed indications of decomposition. The white, fruticose lichen Thamnolia subuliformis apparently increased in abundance in the Drill Site No. 2 mesic site.

\section{Site factors and plant response}

In terms of the number of taxa and the cover values of the affected taxa, the impact of the seawater treatment was most severe in the mesic and dry sites. The wet sites were only mildly affected (Table 10, Figs. 8, 9). Because the seawater penetrated rapidly into the dry-site soils, a significantly smaller surface area was inundated in these sites than in the mesic and wet sites. While this difference is not necessarily reflected in the quadrat data, it should be considered in evaluating the relative impact at the various sites.

Of the three mesic sites, Drill Site No. 2 was the most severely affected. In 1981 only one forb spe-

-Personal communication with R. Haugen, CRREL, 1983. cies, Senecio atropurpureus, was observed in the experimental plots at this site (three small individuals). One shrub, Salix arctica, produced a few leaves and a catkin in early June; however, by mid-July the leaves had withered and abscised. None of the other shrubs in the experimental plots at this site produced foliage during 1981. It may be significant that Drill Site No. 2 had the highest soil-solution conductivity of the three mesic sites in 1981. In the other two mesic sites some forb and shrub growth was evident in 1981 . While the shrub foliage was greatly reduced in these sites, a few leaves were produced by three of the four species at each site. The shrub foliage in these sites appeared to increase slightly between mid-July and mid-August. The new foliage in the West Dock site appeared to be healthy, while some of the wil. lows in the Pad F site developed a chlorotic appearance similar to that observed after the seawater treatment in 1980.

The effects of the seawater treatment on the two dry sites were approximately equivalent. Vegetation damage in these two sites was patchy and probably related to the uneven penetration of the seawater.

The responses of the vegetation at the three wet sites are not comparable. The wet site at West Dock experienced a natural seawater inundation during the fall of 1980 . In the Pad F wet site the vegetative cover deteriorated in $198 \mathrm{I}$ in both the control and the experimental areas. There was considerably less green Drepanocladus lycopodioides var. brevifolius cover than in the previous year, and individuals of Draba spp. were less abundant. The conductivity of the soil solution was abnormally high. These observations suggest that there may be some unknown source of contamination in the area, so the site may not provide a reliable standard by which to measure the effects of the seawater treatment.

Except where the seawater spill did not reach all three plots (i.e. at the Gravel Pit dry site), the extent to which the plants in the experimental plots were affected appeared to be independent of the distance from the spill point. An exception to this was the wet site at Drill Site No. 2, where some of the mosses in the plot closest to the spill point appeared discolored in 1981, while the mosses in the more distant plots did not. Some plants, notably the willows, developed symptoms throughout the spill areas, in some cases up to $10 \mathrm{~m}$ from the actual spill point. None of the plants, even those closest to the spill points, appeared to have been damaged by the physical impact of the water as it was applied to the plots. 
Table 10. Vascular plant response in relation to site factors. Percentages are mean values for three experimental plots.

\begin{tabular}{|c|c|c|c|c|c|c|}
\hline Stte location & $\begin{array}{l}\text { Moisture } \\
\text { category }\end{array}$ & Soill reaction & $\begin{array}{c}\text { Approximate } \\
\text { area } \\
\text { covered by } \\
\text { spill }\left(m^{2}\right)\end{array}$ & $\begin{array}{c}\text { Number of } \\
\text { taxa } \\
\text { affected } \\
\text { in } 1980 \\
\end{array}$ & $\begin{array}{c}\text { Percentage } \\
\text { live cover } \\
\text { with } \\
\text { chlorotic } \\
\text { symptoms }\end{array}$ & $\begin{array}{c}\text { Percentage of } \\
\text { to tal live } \\
\text { vascular plant } \\
\text { cover affected } \\
\text { in } 1980 \\
\end{array}$ \\
\hline $\begin{array}{l}\text { West Dock } \\
\text { Am }\end{array}$ & Mesic & Acidic & 140 & 7 & 26 & 63 \\
\hline $\begin{array}{l}\text { West Dock* } \\
\text { Aw }\end{array}$ & Wet & Acidic & 70 & 0 & 0 & o \\
\hline $\begin{array}{l}\text { Compressor Plant } \\
\text { Bd }\end{array}$ & Dry & Alkaline & 40 & 15 & 24 & 89 \\
\hline $\begin{array}{l}\text { Drill Site } \\
\text { No. } 2 \mathrm{Cm}\end{array}$ & Mesic & Alkaline & 90 & 11 & 21 & 60 \\
\hline $\begin{array}{l}\text { Drill Site } \\
\text { No. } 2 \mathrm{Cw}\end{array}$ & Wet & Alkaline & 90 & 4 & $<1$ & 1 \\
\hline $\begin{array}{l}\text { Gravel Pit† } \\
\text { Dd }\end{array}$ & Dry & Alkaline & 50 & 8 & 29 & 83 \\
\hline $\begin{array}{l}\text { Pad F } \\
\text { Em }\end{array}$ & Mesic & Acidic & 110 & 8 & 25 & 66 \\
\hline $\begin{array}{l}\text { Pad F } \\
\text { Ew }\end{array}$ & Wet & Acidic & Undetermined & 4 & $<1$ & 1 \\
\hline
\end{tabular}

-Vegetation in this site consists entirely of the graminoids Carex subspathacea and Dupontia fisheri.

tPercentages are mean values for two experimental plots.

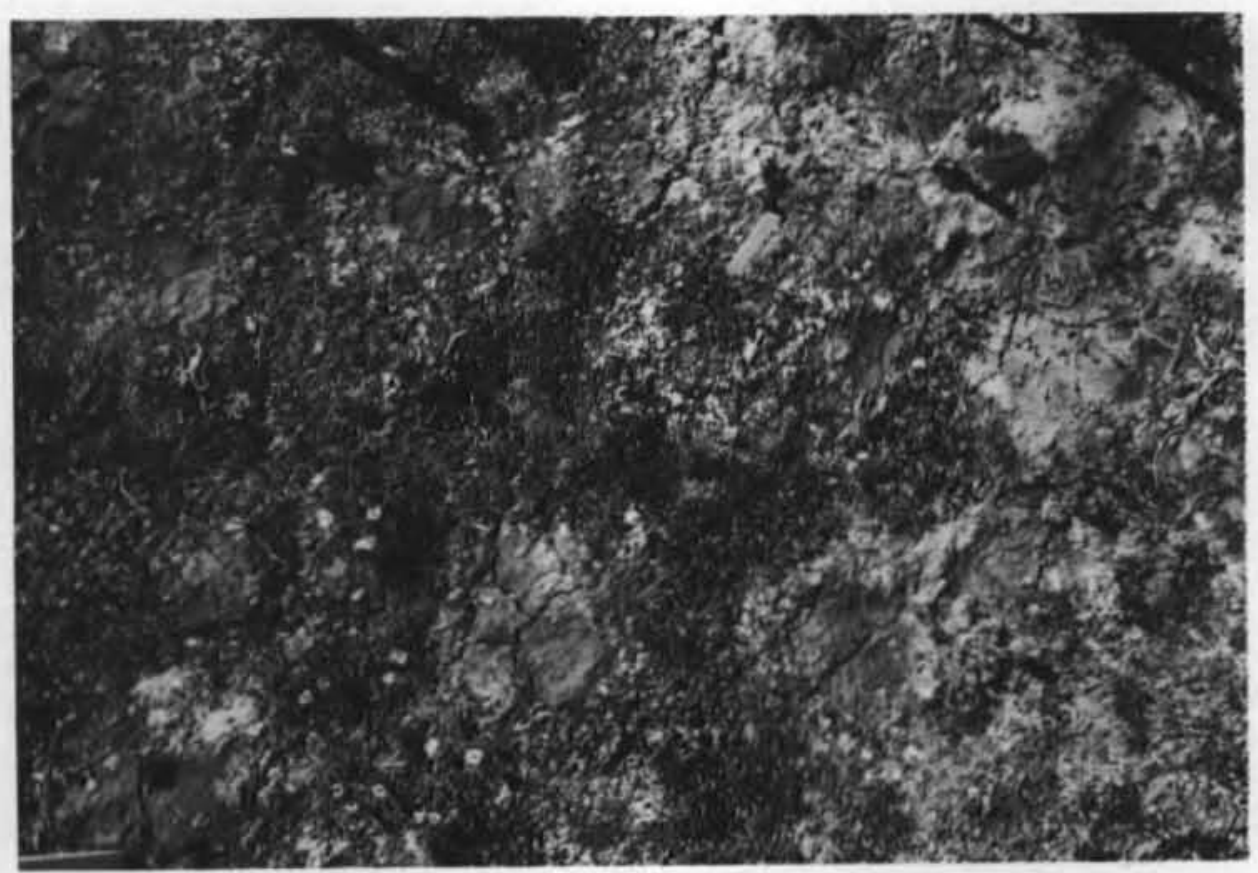

a. Control plot at the Compressor Plant dry site.

Figure 8. Differences between control and experimental plots in 1981. 


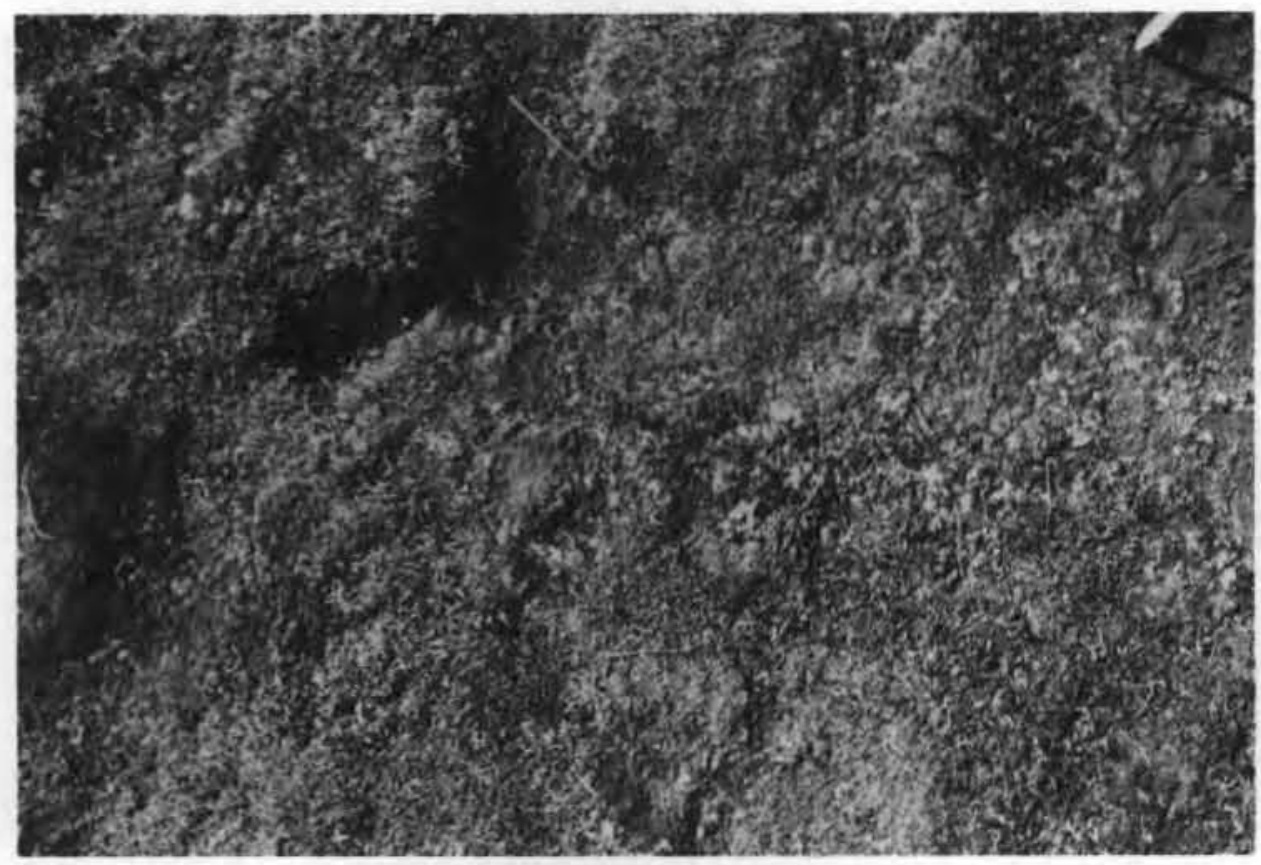

b. Experimental plot at the Compressor Plant dry site. The live vegetative cover decreased from $43 \%$ in 1980 to $15 \%$ in 1981 at this site.

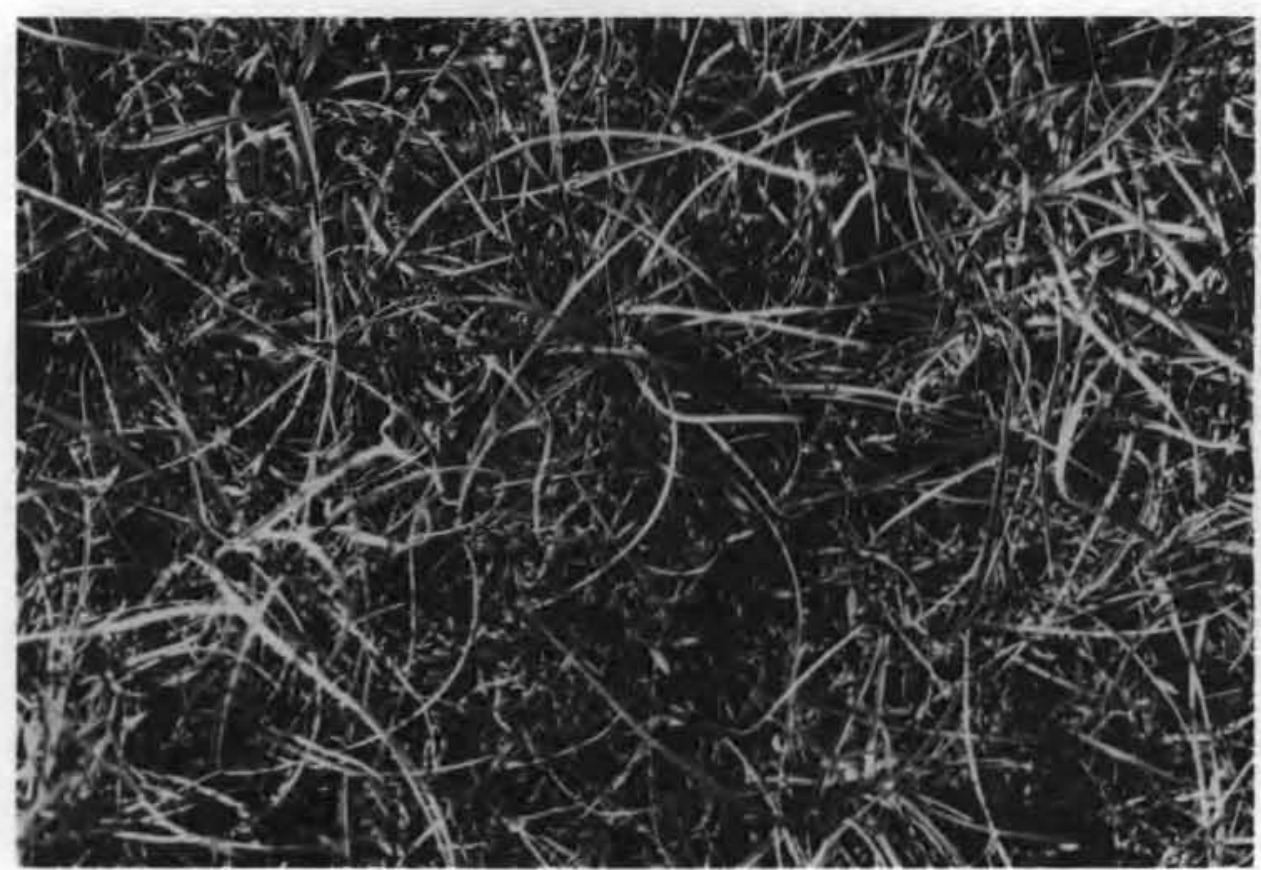

c. Control plot at the Drill Site No. 2 mesic site.

Figure 8 (cont'd). 


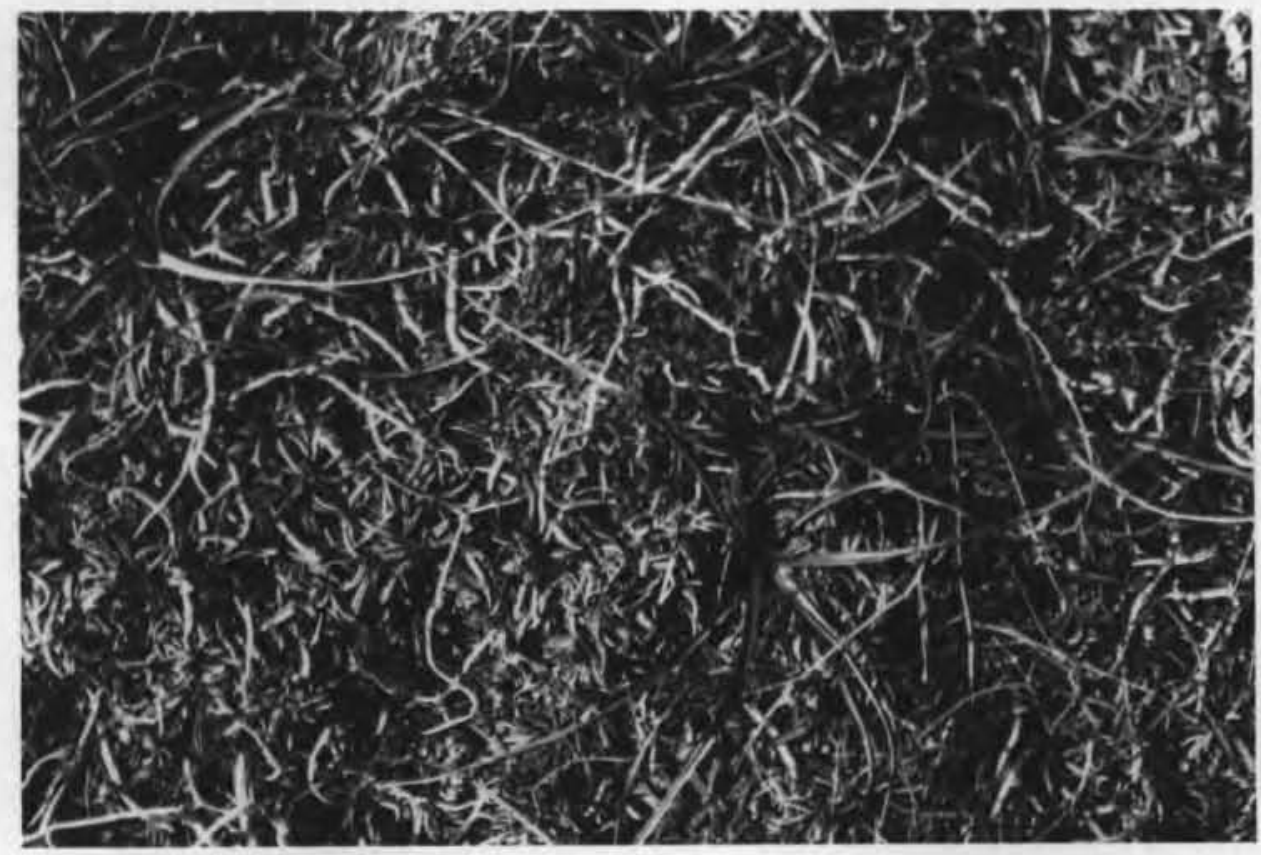

d. Experimental plot at the Drill Site No. 2 mesic site. The gray color is primarily due to dead Dryas integrifolia. The live vegetative cover decreased from $107 \%$ in 1980 to $26 \%$ in 1981 at this site.

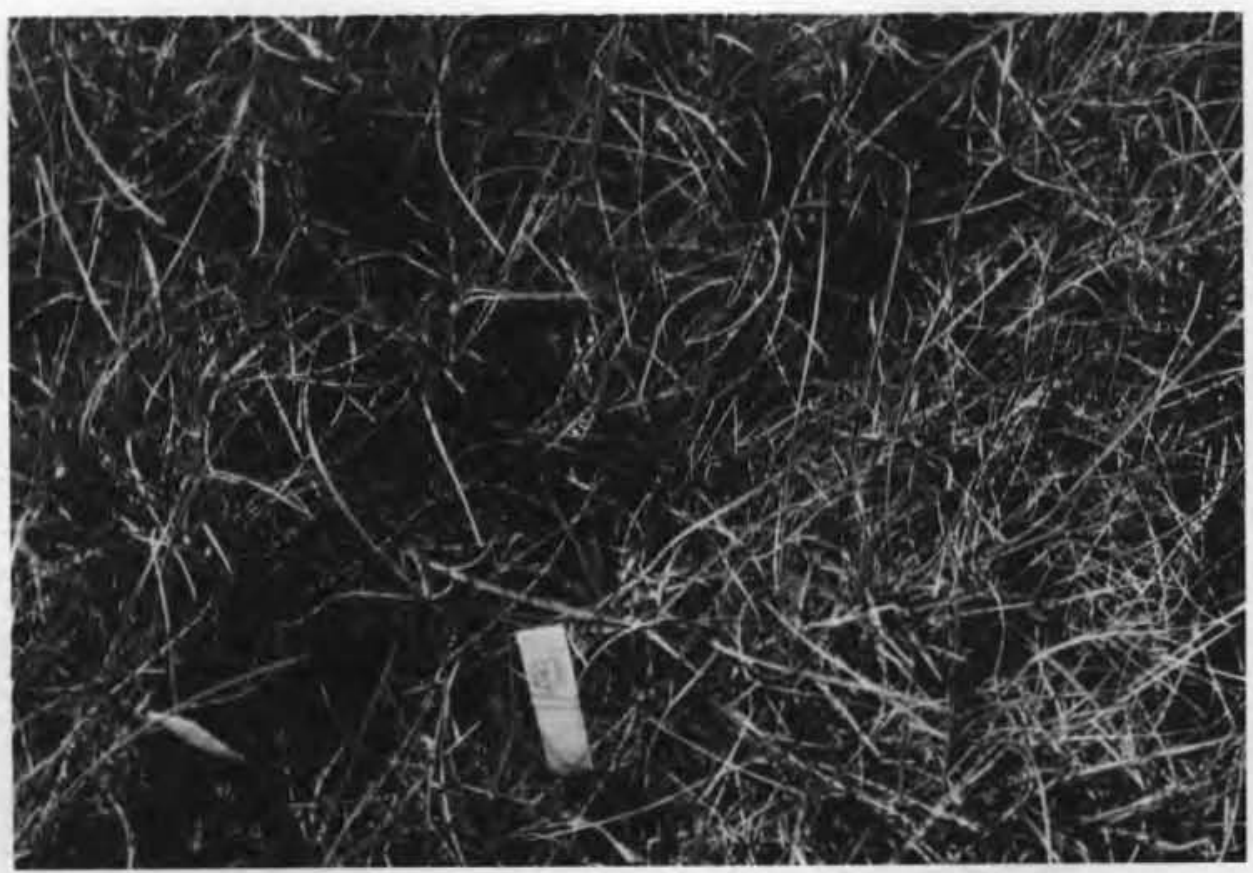

e. Control plot at the Drill Site No. 2 wet site.

Figure 8 (cont'd). Differences between control and experimental plots in 1981. 


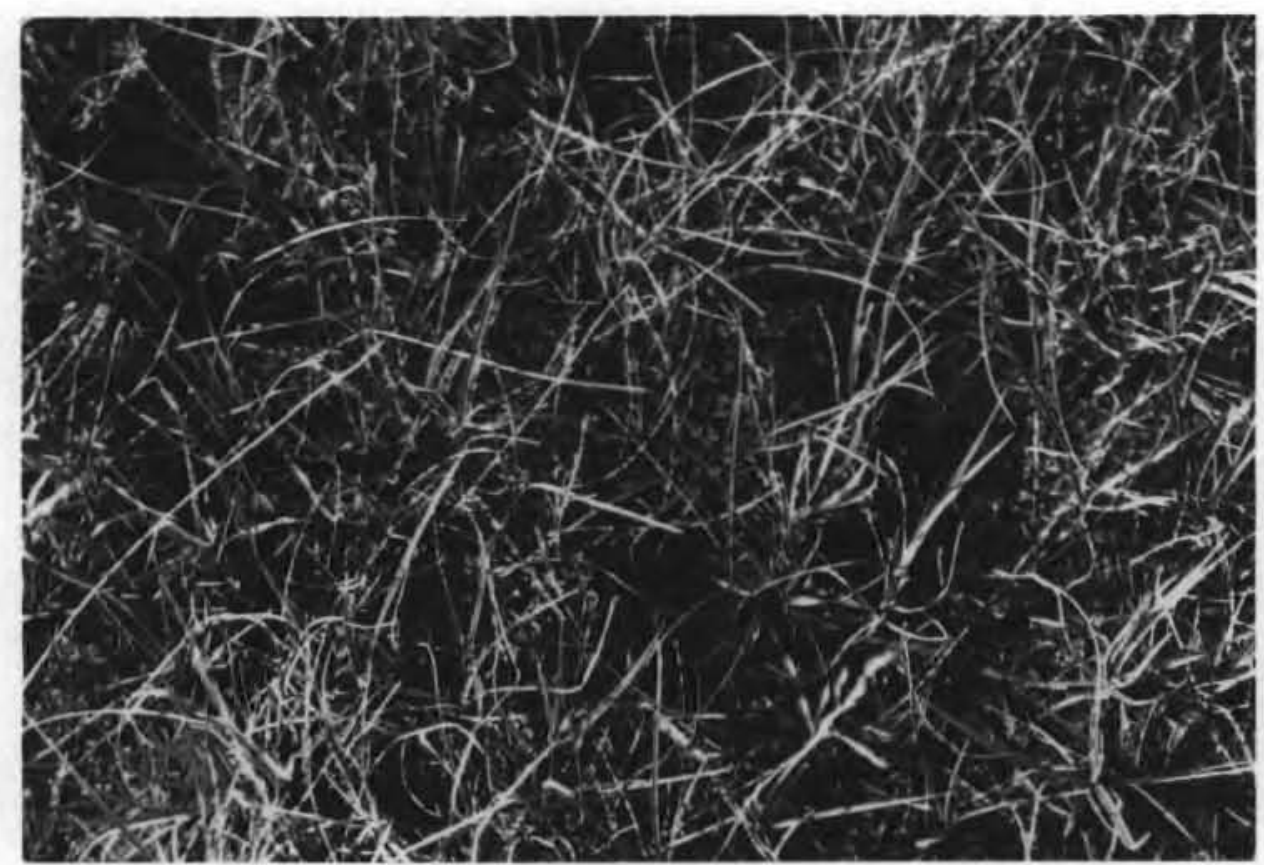

f. Experimental plot at the Drill Site No. 2 wet site. The seawater apparently had little effect on the wet-site vegetation.

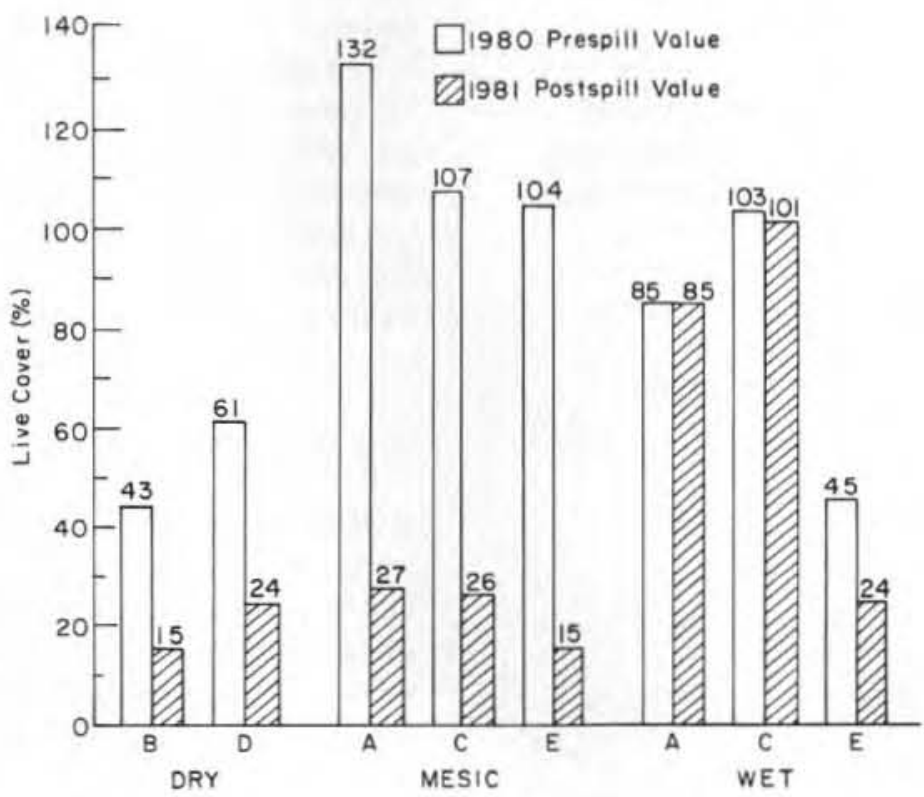

Figure 9. Percent live cover for all vegetation in the experimental plots prior to the seawater treatment in 1980 and one year after the treatment. The cover values are the means for the three experimental plots at each site. Fruticose and crustose lichens were considered to be alive; brown mosses were considered dead. (A: West Dock; B: Compressor Plant; C: Drill Site No. 2; D: Gravel Pit; E: Pad F.) See also Tables 6-9. 
Except for the West Dock wet site the extent to which the plants were affected by the seawater treatment was the same in the coastal as in the inland sites; however, the brief observations made in 1982 suggest that recovery is likely to be more rapid in the coastal sites. Soil reaction did not appear to be significant in determining plant responses (Table 10).

For the short term the saltwater sensitivities of most geobotanical map units are similar to the oilspill sensitivites discussed by Walker et al. (1978). However, in the dry sites, oil will eventually decompose, but salt may actually become more concentrated in some parts of the profile. The wet sites, on the other hand, are more likely to be completely flushed of excess salt in a relatively short time, depending, of course, on the size of low. lying basins. The impact of oil spills may be more apparent at first, but the effects of saltwater spills may prove to last longer, particularly in dry areas.

\section{Soil flora and extracellular soil enzymes}

At all sites there was a significant decrease in the soil enzyme activity in the seawater-treated soils (Table 11). The decrease in cellulase activity reflects decreased hydrolysis of the plant residue cellulose to glucose, a carbon source readily assimilated by soil flora. This should reflect a significant

Table 11. Soil enzyme activity in experimental and control plots at Drill Site No. 2, Pad F and West Dock. Endocellulase activity is expressed as units per hr per gm dry weight of soil, exocellulase activity as mg. glucose equivalents produced per hr per $\mathrm{mg}$ dry weight of soil, and phosphatase activity as mg para. nitrophenol released per hr per gm dry weight of soil. The standard deviations are in parentheses.

\begin{tabular}{llc} 
& Soll enzyme activity \\
Site Experimental plots Control plots & Decrease \\
\hline
\end{tabular}

\begin{tabular}{lccc}
\hline & & \\
& & & \\
$\mathrm{Cm}$ & $3.2(0.9)$ & $4.3(1.0)$ & 26 \\
$\mathrm{Em}$ & $8.1(2.2)$ & $13.2(2.0)$ & 39 \\
$\mathrm{Am}$ & $8.1(2.0)$ & $14.1(2.1)$ & 43 \\
& & & \\
& & Exocellulase & \\
$\mathrm{Cm}$ & $7.1(1.2)$ & $12.2(3.0)$ & 42 \\
$\mathrm{Em}$ & $26.7(4.0)$ & $35.4(4.5)$ & 25 \\
$\mathrm{Am}$ & $58.8(6.2)$ & $85.1(10.1)$ & 31 \\
& & & \\
& & Phosphatase & \\
$\mathrm{Cm}$ & $519.3(100.0)$ & $800(100.0)$ & 35 \\
$\mathrm{Em}$ & $2022.0(241.6)$ & $2995(256.0)$ & 32 \\
$\mathrm{Am}$ & $1360.6(180.0)$ & $1826(96.5)$ & 26 \\
\hline
\end{tabular}

decrease in an important carbon source in July and August, since cellulose is an important oxidative base for microbial carbon dioxide production in tundra soils at these times (Linkins et al. 1980).

In all the seawater-treated mesic plots there was a significant $(25 \%)$ decrease in phosphatase activity. Phosphatase activity represents the enzymatic hydrolysis of organic phosphomonoesters to free inorganic phosphorus, which is presumably a form of phosphorus more available to soil microflora and plant roots (Speir and Ross 1978). The reduction in phosphatase activity, then, represents a reduction in the total available inorganic phosphorus in these soils. Because available phosphorus is often a limiting factor for plant growth in Arctic Coastal Plain soils, this reduction may be very important (Chapin et al. 1978).

Since enzyme activity was assayed under substrate-saturating conditions (zero order), it should represent the amount of enzyme present. These data, then, show a significant loss of enzymes from these soil systems. Because the enzymes are adsorbed, their loss could be because the enzymes are less stable in the soluble state, because they percolated from the organic horizons, or because they were immediately denatured by the salt solution. Regardless of the mechanism the enzyme loss represents a loss of potentially available carbon and phosphorus to the soil flora.

The reduction in the soil respiration rates (Table 12) shows that microbial activity was significantly reduced in all seawater-treated soils. This represents either a direct reduction in microflora oxidative activity due to salt kill or a reduction in available carbon and phosphorus. Since the conductiv. ity levels of the soil solutions were very near those measured during the first year of the treatment, the lower soil respiration rates probably reflect both of these factors.

Deciduous shrubs with ectomycorrhizal root systems seemed to be the most susceptible to seawater damage (Simmons et al. 1980), probably due in part to the relatively shallow roots of these plants. Analyses of the root classes and measurements of root respiration rates showed that significant changes still existed one year after treatment (Tables 12 and 13).

In all treated plots, respiration rates of roots judged to be viable (Antibus and Linkins 1978, Linkins and Antibus 1978, Linkins et al. 1978) were reduced $21-83 \%$ from the controls (Table 12). The number of viable roots was reduced $31-62 \%$, often with significant changes in the composition of the roots (determined by the artificial classification of roots by mantle color) 
Table 12. Soil and ectomycorrhizal root respiration rates in experimental and control plots at Drill Site No. 2, Pad F and West Dock. Respiration rates are expressed as $\mu \mathrm{L} \mathbf{0}_{2}$ per hr per gm dry weight of soil for soils and $\mu \mathrm{L} \mathbf{O}_{2}$ per hr per gm dry weight of root for roots. The standard deviations are in parentheses.

\begin{tabular}{|c|c|c|c|c|}
\hline \multirow[b]{2}{*}{ Site } & \multirow[b]{2}{*}{ Plant species } & \multicolumn{3}{|c|}{ Respiration rate } \\
\hline & & Experimental plots & Control plots & $\begin{array}{c}\text { Decrease } \\
\text { (\%) }\end{array}$ \\
\hline \multicolumn{5}{|c|}{ Soils } \\
\hline $\mathrm{Cm}$ & & $9.3(1.9)$ & $20.2(3.0)$ & 54 \\
\hline Em & & $20.3(5.0)$ & $35.2(0.9)$ & 42 \\
\hline Am & & $36.9(4.8)$ & $46.9(1.8)$ & 22 \\
\hline \multicolumn{5}{|c|}{ Roots } \\
\hline $\mathrm{Cm}$ & Salix arctica & $15.1(3.0)$ & $85.5(5.2)$ & 83 \\
\hline $\mathrm{Em}$ & $\begin{array}{l}\text { Salix reticulata ssp. } \\
\text { reficulata }\end{array}$ & $30.5(8.1)$ & $62.2(10.1)$ & 50 \\
\hline Am & $\begin{array}{l}\text { Salix rotundifolia ssp. } \\
\text { rotundifolia }\end{array}$ & $38.0(6.9)$ & $48.1(8.2)$ & 21 \\
\hline
\end{tabular}

Table 13. Ectomycorrhizal root composition in experimental and control plots at Drill Site No. 2, Pad F and West Dock. Data are expressed as number of roots in a color class per $\mathrm{cm}^{3}$ of soil, and are the mean of the total root counts for three samples. The standard deviations are in parentheses.

\begin{tabular}{|c|c|c|c|c|c|}
\hline \multirow[b]{2}{*}{ Roots } & \multirow[b]{2}{*}{ Site } & \multirow[b]{2}{*}{ Mantle color } & \multicolumn{3}{|c|}{ Number of roots } \\
\hline & & & Experimental plots & Control plots & $\begin{array}{c}\text { Decrease } \\
\text { (\%) }\end{array}$ \\
\hline \multirow[t]{5}{*}{ Salix aretica } & $\mathrm{Cm}$ & White & $4.10(0.50)$ & $5.90(0.50)$ & \\
\hline & & Black & $1.27(0.70)$ & $2.35(0.18)$ & \\
\hline & & Brown & $1.17(0.19)$ & $0.63(0.12)$ & \\
\hline & & Nonmycorrhizal & $0.21(0.05)$ & $0.30(0.06)$ & \\
\hline & & Total & $6.75(0.85)$ & $9.18(0.86)$ & 31 \\
\hline \multirow{5}{*}{$\begin{array}{l}\text { Salix reticulata } \\
\text { ssp, reticulata }\end{array}$} & Em & White & $0.21(0.60)$ & $6.60(1.00)$ & \\
\hline & & Black & $4.15(1.50)$ & $4.63(1.70)$ & \\
\hline & & Brown & 0 & $0.81(0.10)$ & \\
\hline & & Nonmycorrhizal & 0 & $0.18(0.02)$ & \\
\hline & & Total & $4.36(2.10)$ & $12.22(2.32)$ & 62 \\
\hline \multirow{5}{*}{$\begin{array}{l}\text { Salix rotundifolia } \\
\text { ssp. rotundifolia }\end{array}$} & Am & White & $0.75(0.25)$ & $2.28(1.00)$ & \\
\hline & & Black & $2.01(0.90)$ & $1.80(0.82)$ & \\
\hline & & Brown & $0.20(0.25)$ & $0.35(0.32)$ & \\
\hline & & Nonmycorrhizal & 0 & $0.24(0.15)$ & \\
\hline & & Total & $2.96(1.40)$ & $4.67(2.29)$ & 37 \\
\hline
\end{tabular}

(Table 13). Since ectomycorrhizal roots with different mantle colors have different seasonal respiration rates and phosphatase and cellulase activities (Antibus and Linkins 1981, Linkins and Antibus $1982 \mathrm{a}, \mathrm{b})$ and different resistances to osmotic stress (Mexal and Reid 1973), the loss of total root biomass as well as changes in specific mycorrhizal components of the roots could significantly alter the ability of these plants to survive.

\section{Limitations of this study}

This study, initiated in response to the imminent construction of the Waterflood pipeline in the Prudhoe Bay oilfield, was intended to provide a first approximation of the effects of seawater on representative tundra plant communities. The results clearly demonstrate the susceptibility of a significant component of the tundra vegetation to damage by seawater. However, these results 
should be interpreted in light of the following points:

1) Since the seawater was not confined to the experimental plots, the amount of water each plot received could not be accurately determined.

2) The lack of a freshwater control makes it difficult to distinguish between salt-related and inundation-related effects. However, it is unlikely that the effect of the standing water (aside from the effects of the salts) was detrimental to the vegetation. The effects of increased soil moisture in the wet and mesic sites can be neglected because the soils in these sites are constantly saturated or nearly saturated. In the dry sites the shortness of the period of surface saturation following the spill suggests that saturation-related effects are negligible in these areas as well.

3) The results from the experiment apply only to the given experimental conditions. A spill during a different season could be expected to have different effects on the vegetation. A considerably larger spill might not be as effectively diluted by the ambient soil water and could have a detrimental effect on even the wettest sites, particularly if the water were confined, as in the basin of a small pond.

\section{SUMMARY AND CONCLUSIONS}

A single, saturating application of seawater to tundra plants during the 1980 growing season induced symptoms of physiological stress in 21 vascular plant taxa ( 7 shrubs and 14 forbs). Initial symptoms appeared within two weeks of the application and typically consisted of leaf deterioration, followed in some taxa by leaf abscission. While a few plants, which had produced buds prior to treatment, flowered in spite of significant leaf deterioration, there was no sign of recovery in any of the damaged plants during the month following the seawater treatment. One year later the live vascular plant cover in the dry and mesic experimental sites had decreased markedly. The live bryophyte cover in the mesic sites was greatly reduced as well. Reduced cover values were reported for nearly all of the vascular taxa that had developed clear symptoms of stress during the 1980 observation period, as well as for five additional taxa. Many taxa of vascular plants failed to reappear in the dry and mesic experimental plots in 1981; the number of vascular plant taxa was thus reduced by $20-73 \%$ in these sites. The reduction in live vegetative cover ranged from 61 to $86 \%$ in the same sites. The seawater treatment ap- parently had little effect on the vegetation in the wet sites. Neither the number of species nor the total live vegetative cover decreased markedly.

Nearly all of the shrubs and forbs in the treated areas were adversely affected by the seawater. The low salt tolerances of Dryas integrifolia and six species of Salix are particularly significant because these plants constitute the predominant vascular plant cover in many dry and mesic tundra habitats. Graminoids, the predominant vascular plants in wet areas, appeared to be unaffected by the seawater treatment in all but one of the sites. There was no indication in 1981 that other vascular species had begun to colonize any of the experimental sites. Only two lichen taxa developed symptoms within the year following the seawater treatment; however, symptoms may simply develop more slowly in these plants.

Cryptogams, particularly mosses, provide much of the vegetative cover in tundra habitats. In the wet and mesic study sites, bryophytes form a nearly continuous mat over the soil substrate. These plants protect the soil surface from erosion, help insulate and maintain the underlying permafrost, and help provide a habitat for new plant growth. The bryophyte response was hard to interpret injtially because the treated plants developed conditions that looked like normal dormancy, and many bryophytes in the untreated areas surrounding the experimental plots became dormant shortIy after the spill. However, the 1981 vegetation data clearly indicate that the bryophytes in the mesic sites were adversely affected by the treatment; nearly all of the bryophyte cover in these experimental sites remained brown throughout the 1981 observation period. Because dormancy allows bryophytes to survive adverse conditions and resume growth when conditions improve, longterm observations are required to determine the ability of these plants to recover from the effects of seawater.

The wet sites were the least severely affected by the seawater spill. The relative resilience of the vegetation in these sites can be attributed to dilution by the soil water and to the predominance of graminoid vegetation. The vascular plant re. sponses at the much more strongly perturbed mesic and dry sites were roughly equivalent. Slightly more of the total vascular plant cover was damaged in the dry-site experimental plots; however, the mesic-site spills inundated larger surface areas. Because there is a larger percentage of bryophytes in the mesic sites than in the dry sites and the bryophytes did not produce much new growth in 1981, the percentage decrease in the total vege- 
tative cover was much greater in the mesic sites than in the dry sites. The 1981 live cover values for the two types of sites were nearly equivalent, but long-term differences in the recovery potentials of dry and mesic sites may become apparent. Brief observations in 1982 suggest that coastal sites are likely to recover more rapidly than inland sites.

There is no apparent pattern to the losses of enzyme activity at the different plots, even though the West Dock site normally has higher soil solution conductivity values. Since so little is known about the baseline microbiological structural and functional differences among these tundra sites, speculation about the differences in response is pointless. All that can be said is that significant enzyme losses were apparent in all seawatertreated plots.

Soil and root respiration decreases from the seawater treatment, however, do seem to be related to soil-solution conductivity. In both cases the smallest decrease in respiration rate occurred at the West Dock site; these data suggest that more of the soil flora were resistant to saltwater exposure there. Although the total number of viable mycorrhizal root tips does not seem to be related to the soil solution characteristics at the plots, the survival of specific types of mycorrhizal roots may be. Examining the functions of these different root types should allow us to understand the nature of the impact and the prospects for survival of these plants.

In summary, the seawater spill experiment showed that the major plant communities of the Prudhoe Bay region have different tolerances to seawater spills. These differences reflect dif. ferences in the physiological tolerances of the species making up the communities, as well as differences in soil moisture among the sites in which the communities occur. Information on the sensitivities of major plant communities along the regional moisture gradient will be used in producing seawater sensitivity maps that will be useful for routing Waterflood pipelines and for directing cleanup operations in the event of a seawater spill.

The physiological responses of the individual tundra species are not well understood. Dryas integrifolia and the deciduous shrubs with ectomycorrhizal root systems, such as the willows, appear to be particularly sensitive to seawater spills. These plants form the major component of the vascular vegetation in mesic and dry sites. A portion of this study examined soil enzyme activity, soil respiration and mycorrhizal root respiration in the willows one year after the seawater treatment; all were markedly reduced in the plots treated with seawater.

\section{LITERATURE CITED}

Antibus, R.K. and A.E. Linkins (1978) Ectomycorrhizal fungi of Salix rotundifolia Trautv. I. Impact of surface applied Prudhoe Bay crude oil on mycorrhizal structure and composition. Arctic, 31: $366-380$.

Antibus, R.K. and A.E. Linkins (1981) The surface acid phosphatase activities of selected ectomycorrhizal fungi and resynthesized mycorrhizal roots. Mycological Society of America Symposium, 46th Annual Meeting, Bloomington, Indiana.

Burns, R.C. (1978) Soil Enzymes, New York: Academic Press.

Chapin, F.S., R.J. Barsdate and D. Barel (1978)

Phosphorus cycling in Alaskan coastal tundra: A hypothesis for the regulation of nutrient cycling, Oikos, 31: 189-199.

Crum, H.A., W.C. Steere and L.E. Anderson (1973) A new list of mosses of North America north of Mexico. The Bryologist, 76(1): 85-130.

Hale, M.E. and W.L. Culberson (1970) A fourih checklist of the lichens of the continental United States and Canada. The Bryologist, 73(30): 499543.

Herbein, S.B. (1981) Soil phosphates: Factors affecting enzyme activity in arctic tussock tundra and Virginia mineral soils. Master's thesis, Biology Department, Virginia Polytechnic Institute and State University, Blacksburg.

Hultén, E. (1968) Flora of Alaska and Neighboring Territories. Stanford, California: Stanford University Press.

Krauskopf, K.B. (1967) Introduction to Geochemisiry. New York: McGraw-Hill.

Ladd, J.N. and J.H.A. Butler (1975) Humus-enzyme systems and synthetic organic polymer-enzyme analogs. In Soil Biochemistry (A.D. MeLaren and E.H. Paul, Eds.). New York: Marcel-Dekker, vol. 5, pp. 143-194.

Linkins, A.E. and R.K. Antibus (1978) Ectomycorrhizal fungi of Salix rotundifolia Trautv. II. Impact of surface applied Prudhoe Bay crude oil on mycorrhizal root respiration and cold acclimation. Arctic, 31: 381-393.

Linkins, A.E. and R.K. Antibus (1982a) Mycorrhizae of Salix rotundifolia Trautv. in coastal arctic tundra. First International Symposium on Arctic Mycology. Seattle, Washington: University of Washington Press.

Linkins, A.E. and R.K. Antibus (1982b) Carbonnutrient exchange in roots and rhizosphere. Symposium on Carbon-Nutrient Interactions in Plants and in Ecosystems. American Institute of Biological Sciences, State College, Pennsylvania. 
Linkins, A.E., R.M. Atlas and P. Gustin (1978) Effects of surface applied crude oil on soil and vascular plant root respiration, soil cellulase, and hydrocarbon hydroxylase at Barrow, Alaska. Arctic, 31: 355-365.

Linkins, A.E., K.R. Everett and J.N. Neal (1980) Cellulase and chitinase activities in tundra soils of different vegetation types along moisture gradient. Proceedings of the Soil Science Society of America Meetings, 1980, Detroit Michigan, p. 156.

Linkins, A.E. and J.L. Neal (1982) Cellulase, chitinase and protease activities associated with microsuccessional patterns in tussock tundra. $\mathrm{Hol}$ arctic Ecology, 5: 135-139.

McLaren, A.D. (1975) Soil as a system of humus and clay immobilized enzymes. Chemica Scripta, 8: 97-99.

Mexal, J. and C.P.P. Reid (1973) The growth of selected mycorrhizal fungi in response to induced water stress. Canadian Journal of Botany, 51: 1579-1588.

Vannipieri, P., B. Ceccanti, S. Cervelli and A. Matharese (1980) Extraction of phosphatase, urease, protease, organic carbon and nitrogen. Journal of the Soil Science Society of America, 44: 1011-1016.

Reimnitz, E. and D.K. Mauer (1979) Effects of storm surges on the Beaufort Sea Coast, Northern Alaska. Arctic, 32(4): 329-344.

Shimwell, D.W. (1971) The Description and Classification of Vegetation. Seattle, Washington: University of Washington Press.

Simmons, C.L., D.A. Walker and P.J. Webber (1980) Sea water tolerances of selected vegetation of Prudhoe Bay, Alaska. Unpublished report to
CRREL. Institute of Arctic and Alpine Research, University of Colorado, Boulder.

Sinsabaugh, R.L., E.F. Benfield and A.E. Linkins (1981) Cellulase activity associated with decomposition of leaf litter in a woodland stream. Oikos, 36: $184-190$.

Spaulding, B.P. (1977) Enzymatic activities related to the decomposition of coniferous leaf litter. Journal of the Soil Science Society of America, 41: 622-627.

Speir, T.W. and D.J. Ross (1978) Soil phosphatase and sulphatase. In Soil Enzymes (R.G. Burns, Ed.). New York: Academic Press. pp. 197-250.

U.S. Army Corps of Engineers (1980) Draft environmental impact statement, Prudhoe Bay Oilfield Waterflood Project. Vol. I. Alaska District, Anchorage.

Walker, D.A. and P.J. Webber (1980) Master maps and ecological data related to potential impacts of Project Waterflood at Prudhoe Bay, Alaska. Unpublished report to Dames and Moore. Institute of Arctic and Alpine Research, University of Colorado, Boulder.

Walker, D.A., P.J. Webber, K.R. Everett and J.E. Brown (1978) Effects of crude oil and diesel oil spills on plant communities at Prudhoe Bay, Alaska, and the derivation of oil spill sensitivity maps. Arctic, 31(3): 242-259.

Walker, D.A., K.R. Everett, P.J. Webber and J. Brown (1980a) Geobotanical atlas of the Prudhoe Bay region, Alaska. CRREL Report 80-14.

Walker, D.A., K.R. Everett and P.J. Webber (1980b) Vegetation, soil and landform reconnaissance survey in the Kuparuk. Institute of Arctic and Alpine Research, University of Colorado, Boulder. 


\section{APPENDIX: PLANT TAXA INCLUDED IN THIS STUDY}

\section{VASCULAR PLANTS}

Voucher collections for all taxa were sent to the herbaria of the University of Colorado (vascular plants and lichens) and the University of Alaska (bryophytes). Plant names are according to Hultén (1968) for vascular plants, Hale and Culberson (1970) for lichens and Crum et al. (1973) for bryophytes.

Androsace chamaejasme Host. ssp. lehmanniana (Spreng.) Hult. Artemisia borealis Pall.

Astragalus umbellatus Bunge

Braya purpurascens (R. Br.) Bunge

Cardamine hyperborea O.E. Schulz (= C. digitata Richards.)

Carex aquatilis Wahlenb. (including $C$. stans Drej.)

Carex bigelowii Torr.

Carex membranacea Hook.

Carex misandra $\mathrm{R}$. Br.

Carex rariflora (Wahlenb.) J.E. Sm.

Carex rupestris All.

Carex scirpoidea Michx.

Carex subspathacea Wormsk.

Cassiope tetragona (L.) D. Don ssp. tetragona

Chrysanthemum integrifolium Richards.

Draba hirta L. (= D. glabella Pursch)

- Draba cf. lactea Adams

Draba macrocarpa Adams $(=D$, bellii Holm)

Draba sp.

Dryas integrifolia M. Vahl ssp. integrifolia

Dupontia fisheri $\mathrm{R}$. Br. cf. ssp. psilosantha

*Equisetum variegatum Schleich.

Eriophorum angustifolium Honck. ssp. subarcticum (Vassil.) Hult.

*Eriophorum cf. russeolum Fr.

Eriophorum vaginatum $\mathrm{L}$.

Eutrema edwardsii R. Br.

Juncus biglumis L.

*Juncus sp.

Lloydia serotina (L.) Rchb.

Melandrium affine J. Vahl [ = Silene involucrata (Cham. and Schlecht.) Bocq.]

Melandrium apetalum (L.) Fenzl. ssp. arcticum (Fr.) Hult. [ = Silene uralensis

(Rupr.) Bocquet]

Minuartia arctica (Stev.) Aschers and Graebn.

Oxytropis deflexa (Pall.) DC. var. foliolosa (Hook.) Barneby

Oxytropis nigrescens (Pall.) Fisch. ssp. bryophila (Greene) Hult.

Papaver lapponicum (Tolm.) Nordh. ssp. occidentale (Lundstr.) Knaben

Papaver macounii Greene

Parrya nudicaulis (L.) Regel. ssp, nudicaulis

Pedicularis capitata Adams

Pedicularis kanei Durand (= P. lanata Cham. and Schlecht.)

Pedicularis sudetica Willd. ssp. albolabiata

*Indicates field identifications only (no voucher specimens). 
Petasites frigidus (L.) Franch.

Polygonum viviparum $\mathrm{L}$.

Potentilla pulchella $\mathrm{R}$. Br.

Primula borealis Duby

Puccinellia andersonit Swallen

Salix arctica Pall.

Salix lanata L. ssp. richardsonii (Hook.) A. Skvortz.

Salix ovalifolia Trautv, var. ovalifolia

Salix pulchra Cham. $[$ = Salix planifolia Pursh ssp. pulchra (Cham.) Argus var. pulchra]

Salix reticulata L. ssp. reticulata

Salix rotundifolia Trautv. ssp. rotundifolia

Saxifraga cernua L.

Saxifraga foliolosa $\mathrm{R}$. Br.

Saxifraga hirculus $\mathrm{L}$.

Saxifraga oppositifolia L. ssp. oppositifolia

Sedum rosea (L.) Scop. ssp. integrifolium (Raf.) Hult.

Senecio atropurpureus (Ledeb.) Fedtsch. ssp. frigidus (Richards.) Hult.

Silene acaulis L.

Stellaria edwardsii $\mathrm{R}$. Br.

Stellaria laeta Richards.

Taraxacum phymatocarpum J. Vahl

\section{MOSSES}

*Aulacomnium acuminatum (Lindb. and Arnell) Kindb.

Aulacomnium palustre (Hedw.) Schwaegr.

Aulacomnium turgidum (Wahlenb.) Schwaegr.

Brachythecium sp.

Bryum cf. pseudotriquetrum (Hedw.) Gaertn., Meyer and Scherb.

Calliergon richardsonii (Mitt.) Kindb. ex Warnst.

Calliergon sarmentosum (Wahlenb.) Kindb.

Campylium stellatum (Hedw.) C. Jens, var. arcticum (Williams) Sav,-Ljub.

Catoscopium nigritum (Hedw.) Brid.

Cinclidium latifolium Lindb.

Dicranum scoparium Hedw.

Dicranum cf. spadiceum Zett.

Distichium capillaceum (Hedw.) B.S.G.

Distichium sp.

Ditrichum flexicaule (Schwaegr.) Hampe

Drepanocladus lycopodioides (Brid.) Warnst. var. brevifolius (Lindb.) Moenk

Drepanocladus revolvens (Sw.) Warnst.

'Drepanocladus uncinatus (Hedw.) Warnst.

*Encalypta sp.

Hylocomium splendens (Hedw.) B.S.G.

Hypnum bambergeri Schimp.

Hypnum procerrimum Mol.

Hypnum revolutum (Mitt.) Lindb.

Hypnum sp.

Meesia triquetra (Richt.) Ängstr.

Mnium rugicum Laur. ( = Plagiomnium ellipticum)

Oncophorus wahlenbergii Brid.

*Indicates field identifications only (no voucher specimens). 
Orthothecium chryseum (Schwaegr. ex Shultes) B.S.G.

Pogonatum alpinum (Hedw.) Roehl. (= Polytrichastrum alpinum)

Polytrichum juniperinum Hedw.

Thuidium abietinum (Hedw.) B.S.G.

Tomenthypnum nitens (Hedw.) Loeske

Tortula ruralis (Hedw.) Gaertn., Meyer and Scherb.

\section{HEPATICS}

Ptilidium ciliare (Web.) Hampe

\section{LICHENS}

Alectoria nigricans (Ach.) Nyl.

Caloplaca sp.

Cetraria cucullata (Bell.) Ach.

Cetraria islandica (L.) Ach.

Cetraria nivalis (L.) Ach.

Cetraria richardsonii Hook.

*Cladonia cf. gracilis (L.) Willd.

*Cladonia cf. squamosa (Scop.) Hoffm.

Cladonia sp.

Cornicularia divergens Ach.

Dactylina arctica (Hook.) Nyl.

Evernia perfragilis Llano

Fulgensia bracteata (Hoffm.) Raes.

Hypogymnia subobscura (Vain.) Poelt.

Lecanora epibryon (Ach.) Ach.

* Nephroma sp.

*Ochrolechia frigida (Sw.) Lynge

*Pertusaria sp.

*Physconia muscigena (Ach.) Poelt

Solorina saccata (L.) Ach.

Thamnolia subuliformis (Ehrh.) W. Culb. 